Fakulteta za turizem

\title{
PRIROČNIK ZA PISANJE IN UREJANJE BESEDIL FAKULTETE ZA TURIZEM UNIVERZE $V$ MARIBORU
}

\author{
Urednik: \\ dr. Mladen Knežević
}





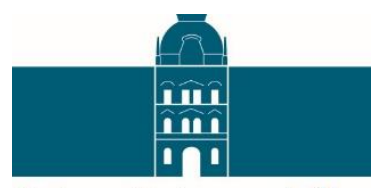

Univerzitetna založba

Univerze v Mariboru

\title{
PRIROČNIK ZA PISANJE IN UREJANJE BESEDIL FAKULTETE ZA TURIZEM UNIVERZE V MARIBORU
}

Strokovna monografija

\author{
Urednik: \\ dr. Mladen Knežević
}

Avgust, 2017 
Naslov: Priročnik za pisanje in urejanje besedil Fakultete za turizem Univerze v Mariboru

Podnaslov: Strokovna monografija

Urednik: izr. prof. dr. Mladen Knežević (Univerza v Mariboru, Fakulteta za turizem)

Avtorji: doc. dr. Mitja Gorenak (Univerza v Mariboru, Fakulteta za turizem), doc. dr. Borut Vojinović (Univerza v Mariboru, Fakulteta za turizem), asist. dr. Andreja Trdina (Univerza v Mariboru, Fakulteta za turizem), pred. Boris Prevolšek, mag. (Univerza v Mariboru, Fakulteta za turizem), doc. dr. Marko Koščak (Univerza v Mariboru, Fakulteta za turizem), asist. Barbara Pavlakovič (Univerza v Mariboru, Fakulteta za turizem), asist. Maja Rosi (Univerza v Mariboru, Fakulteta za turizem), asist. Nejc Pozvek (Univerza v Mariboru, Fakulteta za turizem)

Jezikovna recenzija: Lekteja, Lektoriranje, Teja Bačar, s. p.

Izdajateljica: Univerza v Mariboru, Fakulteta za turizem, Univerza v Mariboru, Cesta prvih borcev 36, 8250 Brežice, Slovenija, tel. +386 820540 10, http://ft.um.si, ft@um.si

Založnik: Univerzitetna založba Univerze v Mariboru, Slomškov trg 15, 2000 Maribor, Slovenija, tel. +3862 25042 42, http://press.um.si, zalozba@um.si

Izdaja: Prva izdaja

Vrsta publikacije: Elektronsko gradivo

Dostopno na: http://press.um.si/index.php/ump/catalog/book/264

Izid: 2017

\section{(c) Univerzitetna založba Univerze v Mariboru}

Vse pravice pridržane. Brez pisnega dovoljenja založnika je prepovedano reproduciranje, distribuiranje, predelava ali druga uporaba tega dela ali njegovih delov v kakršnemkoli obsegu ali postopku, vključno s fotokopiranjem, tiskanjem ali shranjevanjem v elektronski obliki.

Ta priročnik sta obravnavala in potrdila Komisija za študijske zadeve Fakultete za turizem ter Senat Fakultete za turizem.

CIP - Kataložni zapis o publikaciji

Univerzitetna knjižnica Maribor

$001.89(035)(0.034 .2)$

PRIROČNIK za pisanje in urejanje besedil Fakultete za turizem Univerze v Mariboru [Elektronski vir] : strokovna monografija / urednik Mladen Knežević ; [avtorji Mitja Gorenak ... et al.]. - 1. izd. - El. priročnik. Maribor : Univerzitetna založba Univerze, 2017

Način dostopa (URL): http://press.um.si/index.php/ump/catalog/book/264

1. Gorenak, Mitja 2. Knežević, Mladen, sociolog

COBISS.SI-ID 92770305

ISBN: $\quad 978-961-286-076-9$ (pdf)

DOI: https://doi.org/10.18690/978-961-286-076-9

Cena: Brezplačen izvod

Odgovorna oseba prof. dr. Igor Tičar, rektor Univerze v Mariboru založnika:

DOI https://doi.org/10.18690/978-961-286-076-9

(C) 2017 Univerzitetna založba Univerze v Mariboru

Dostopno na: http://press.um.si 


\title{
PRIROČNIK ZA PISANJE IN UREJANJE BESEDIL FAKULTETE ZA TURIZEM UNIVERZE V MARIBORU
}

\author{
dr. Mladen Knežević
}

\section{POVZETEK}

Učni proces na fakulteti ne zahteva samo udeležbe na predavanjih in dejavnega sodelovanja na vajah, temveč tudi intenzivno individualno delo študenta. To se mnogokrat predstavi v obliki seminarske naloge oziroma pisnega dela. Najbolj pomembno samostojno delo študenta pa je zagotovo zaključna - diplomska ali magistrska naloga. Da bi študentom Fakultete za turizem Univerze $v$ Mariboru predstavili in olajšali pripravo pisnih del, smo na fakulteti pripravili priročnik za pisanje in urejanje besedil. Strokovna monografija zajema poglavja, ki študenta vodijo skozi celoten proces raziskovanja in pisanja dela. Od začetnega iskanja ideje, osnov znanstvenega pisanja in raziskovanja $v$ turizmu, do posameznih korakov raziskovalnega procesa in raziskovalnih metod. $V$ strokovno monografijo je vključeno tudi poglavje o osebnih odnosih, ki še posebej nagovarja odnos med študentom in mentorjem pri pisanju zaključnih del. Priročnik podaja tudi praktične nasvete o jezikovnem in tehničnem oblikovanju besedila ter navajanju literature in virov. Strokovna monografija tako združuje temeljne informacije, ki jih bodo pri svojem delu uporabljali študenti in predavatelji, saj bodo skupaj sledili enotnim smernicam pisanja besedil v turizmu na Fakulteti za turizem.

KLUUČNE BESEDE: Pisanje besedil, urejanje besedil, raziskovanje, citiranje, tehnično oblikovanje besedil

KORESPONDENČNI NASLOV: Univerza v Mariboru, Fakulteta za turizem, Cesta prvih borcev 36, 8250 Brežice, Slovenija, e-pošta: ft@um.si.

DOI https://doi.org/10.18690/978-961-286-076-9

ISBN 978-961-286-076-9 (pdf)

(C) 2017 Univerzitetna založba Univerze v Mariboru

Dostopno na: http://press.um.si 


\title{
HANDBOOK FOR WRITING AND EDITING TEXTS OF THE FACULTY OF TOURISM OF THE UNIVERSITY OF MARIBOR
}

\author{
Mladen Knežević, Ph.D.
}

\section{ABSTRACT}

The learning process at the faculty requires not only attending lectures and active participation in the tutorials, but also intensive individual work of a student, which is often presented in the form of a seminar paper. However, the most important individual work of a student is definitely a final paper - a diploma or a master's thesis. In order to present and facilitate the preparation of written works for the students of the Faculty of Tourism of the University of Maribor, we have prepared this handbook for writing and editing texts at the faculty. The professional monograph covers the chapters that lead the student through the whole process of research and writing their paper. From the initial search of the research idea and the basics of scientific writing and research in tourism, to the individual steps of the research process and research methods. The professional monograph also includes a chapter on personal relationships, which in particular addresses the relationship between a student and a mentor in the process of preparing the paper or thesis. The handbook also provides practical advice on language and text designing, as well as instructions for citing references. The professional monograph, thus, combines basic information that both students of tourism and their lecturers will use in their study and work processes, as they will follow the uniform guidelines for writing texts in tourism at the Faculty of Tourism.

KEY WORDS: Writing texts, editing, research, citing, text designing

CORRESPONDENCE ADDRESS: University of Maribor, Faculty of Tourism, Cesta prvih borcev 36, 8250 Brežice, Slovenia, e-mail: ft@um.si.

DOI https://doi.org/10.18690/978-961-286-076-9

ISBN 978-961-286-076-9 (pdf)

(C) 2017 University of Maribor Press

Available at: http://press.um.si 


\section{KAZALO VSEBINE}

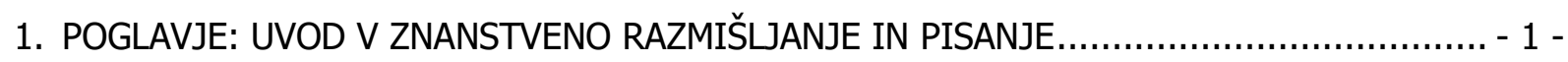

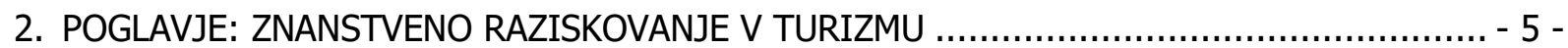

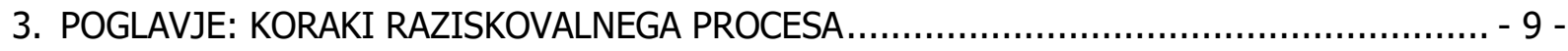

4. POGLAVJE: OPREDELITEV NAČINA RAZISKOVANJA; MED KVALI- IN KVANTITATIVNIM... - 21 -

5. POGLAVJE: OSEBNI ODNOSI V ZNANSTVENEM PISANJU $-33-$

6. POGLAVJE: JEZIK IN SLOG PISANJA. $-41-$

7. POGLAVJE: NAVAJANJE LITERATURE IN VIROV $-47-$

8. POGLAVJE: OBLIKOVANJE BESEDILA $-62-$ 



\section{UVODNIK}

Pisni izdelek študenta $v$ univerzitetnem akademskem okolju ni samo naloga $v$ učnemu procesu (kar seveda tudi je), ta izdelek je tudi kultura sui generis ${ }^{1}$, ali nekoliko natančneje napisano, je del kulture. In ta trditev, da gre za del kulture, se ne nanaša samo na kulturne obrazce posameznika, ki piše izdelek; gre tudi za širitev in poglabljanje kulturnega pristopa akademske institucije, $v$ kateri se to delo opravlja. Zato smo pedagoški sodelavci hvaležni študentom za vsak njihov napor pri študijskem delu.

Ravno tako $v$ primeru te monografije ne gre samo za navodila študentom, kako je treba pripraviti nek pisni izdelek, oziroma za opomnik mentorjem za nekatere morda malo pozabljene elemente strukture pisnega izdelka v akademskem napredovanju njihovih kandidatov. Gre za skupni prispevek skupni kulturi. Po mojem mnenju namreč ne obstaja kulturni turizem kot neka posebna kategorija. In to ne zato, ker ni jasnih razmejitev med kulturnim in drugimi oblikami turizma. Ta kategorija ne obstaja zato, ker je turizem sam kultura, ne le del neke obstoječe, več ali manj lokalne oziroma lokalizirane kulture. Je kultura sama. In ravno iz tega zornega kota, turizma kot kulture, ponujamo pričujoče gradivo: ne kot navodilo za izdelavo pisnih izdelkov, ampak kot poziv mentorjem in študentom za sodelovanje pri širjenju kulturnih obzorij $v$ turistični dejavnosti v slovenski družbi. Vsak vaš izdelek je nov prispevek $\mathrm{h}$ kulturi in istočasno test o tem, ali fakulteta dobro in kako dobro opravlja svoje poslanstvo razvoja ter izpopolnitve slovenskega kulturnega prostora.

Ker pomeni kultura predvsem razvoj, pričujoča monografija nima vloge zastavljanja kriterijev in ne pravil. Je spremljevalec na poti razvoja in napredovanja tako študentov kot tudi pedagoških sodelavcev. Razvoj se namreč nikoli ne ustavi na neki referenčni točki. Je neprekinjeno potovanje $v$ prihodnost.

Pri pripravi te monografije so sodelovali mnogi. Ne samo avtorji, ki so podpisani pod posameznimi prispevki, ampak tudi njihovi mentorji in avtorji, katerih dela so z veseljem prebirali in jih vgradili $v$ temelje svojega akademskega napredovanja. Ravno to je lastnost kulture - neprekinjen razvoj in naslanjanje na prednike. Pa še mnogo več: naslanjanje na naslednike in njihovo željo in sposobnost, da neke ideje popeljejo $v$ neskončnost. In ravno to pedagoški sodelavci pričakujemo od svojih študentov: da $v$ bodočnost te kulture odnesejo znanja, želje, možnosti in sposobnosti naše generacije akademskih stanovalcev tega koščka sveta, ki mu pravimo Slovenija.

K objavi te monografije so prispevali avtorji dr. Mitja Gorenak, dr. Borut Vojinovič, dr. Marko Koščak, dr. Andreja Trdina, Boris Prevolšek, Maja Rosi, Barbara Pavlakovič ter Nejc Pozvek. Vsem se iskreno zahvaljujem za njihovo investicijo $v$ ta skupni izdelek. Posebej je treba omeniti delo kolega dr. Mitje Gorenaka, ki je idejo te monografije pripeljal na dan, ves čas skrbel za njeno ustvarjanje in jo pripeljal do njenega končnega videza, ki ga ponujamo našim študentom in pedagoškim kolegom, ki poučujejo na Fakulteti za turizem Univerze v Mariboru.

dr. Mladen Knežević, urednik

\footnotetext{
${ }^{1}$ Iz latinskega jezika, nanaša se na nekaj, kar je posebne vrste, torej v tem primeru izvirna kultura, svoje vrste.
} 



\title{
1. POGLAVJE
}

\section{UVOD V ZNANSTVENO RAZMIŠLJANJE IN PISANJE}

\author{
Avtor: dr. Mitja Gorenak
}

DOI: https://doi.org/10.18690/978-961-286-076-9.1

Raziskovanje $v$ turizmu se povsem enako kot $v$ vseh ostalih znanstvenih disciplinah nenehno razvija. Žal moramo ugotoviti, da kljub vsemu turizem še vedno ni priznan kot samostojna znanstvena disciplina. Multidisciplinarna narava raziskovanja $v$ turizmu in tudi zelo različni interesi, tako $v$ znanosti kot tudi v praksi, so $v$ veliki meri razlog za to, da se turizem še ni uveljavil kot samostojna znanstvena disciplina, saj jo (pre)mnogi dokaj poenostavljeno le vključujejo kot podkategorijo katere druge obstoječe znanstvene discipline. Prav $\mathrm{v}$ tem kontekstu je treba poudariti, da moramo pri raziskovanju $\mathrm{v}$ turizmu slediti uveljavljenim načelom znanstvenega razmišljanja in pisanja, saj nam ta lahko pomagajo dosegati kakovost znanstvenega raziskovanja $\mathrm{v}$ turizmu in posledično uveljaviti turizem kot samostojno znanstveno disciplino.

Znanstveno besedilo je kompleksno; da ga posameznik lahko napiše, mora najprej posvetiti precej časa znanstvenemu razmisleku. Ob tem je treba jasno povedati, da je znanstveno razmišljanje pravzaprav stvar pristopa k razmišljanju, ki je neodvisno od raziskovalnega področja; tako $v$ turizmu kot $v$ katerikoli drugi znanstveni disciplini se je treba $v$ znanstveno razmišljanje poglobiti. Najprej je treba opredeliti, kaj je namen samega raziskovanja, saj je to vodilo, ki nas spremlja skozi celoten raziskovalni proces. Več o namenu raziskovanja sicer govorimo v nadaljevanju, a sam namen raziskovanja $v$ osnovi znanstveno raziskovanje razdeli v dve veliki skupini; tako na eni strani govorimo o temeljnem znanstvenem raziskovanju ter na drugi strani o aplikativnem znanstvenem raziskovanju.

Temeljno raziskovanje je nekoč predstavljalo večinski delež raziskovanja in je bilo izjemnega pomena za razvoj človeške civilizacije, temeljne raziskave namreč pospešujejo razvoj teorij. Cilj temeljnih raziskav je popolnoma jasen - novo odkritje (Easterby-Smith, Thorpe in Lowe, 2007). Na tem mestu je treba jasno povedati, da so odkritja redka in lahko tudi predvsem povsem nepredvidljiva ali pa do neke mere pričakovana glede na pretekla raziskovanja. Vendar ko je posledica raziskave preskok $v$ miselnosti, nekakšna nova razlaga, ki spreminja dotedanje obstoječe razmišljanje o raziskovani temi, lahko govorimo o odkritju. Odkritja kljub vsemu predstavljajo le enega izmed možnih zaključkov temeljne raziskave, sicer tistega najslajšega za vsakega raziskovalca. Takrat, ko je rezultat temeljnega znanstvenega dela nov način obdelave istega problema, morebiti nov tehnološki pristop, govorimo o invenciji (ibid.). To je druga oblika zaključka temeljnega znanstvenega raziskovanja. Obstoja še tretji možen rezultat temeljnega raziskovanja, ki je sicer manj priljubljen - gre za refleksijo. Takrat ko raziskovalec kot zaključek temeljnega raziskovanja opredeli uporabo obstoječe teorije ali tehnike $v$ nekem povsem drugačnem kontekstu uporabe na organizacijskem in družbenem področju, lahko govorimo o refleksiji uporabe teorije ali tehnike (ibid.).

Aplikativno znanstveno raziskovanje je usmerjeno v reševanje realnih problemov (EastervySmith, Thorpe in Lowe, 2007). Osredotoča se na identifikacijo specifičnih problemov 
organizacije ali identifikacijo nekih praktičnih problemov v vsakdanjem okolju (ibid.). Za aplikativno raziskovanje je značilno, da je osnovano na znanju, dobljenem skozi temeljne raziskave, in je usmerjeno $v$ doseganje nekega praktičnega oziroma uporabnega cilja. Aplikativno raziskovanje tako razvija ideje temeljnega raziskovanja $v$ uporabno obliko. Tako lahko rečemo, da je le-to razvojno naravnano in močno integrirano $v$ razvoj gospodarstva (Lorber, 2003).

Razmerje med temeljnim in aplikativnim raziskovanjem se spreminja; če je nekoč temeljno raziskovanje predstavljalo večinski delež raziskovanja, je danes slika bolj uravnotežena. Medtem ko raziskovalne institucije in države še vedno $v$ večji meri podpirajo temeljno raziskovanje, je aplikativno raziskovanje deležno večje podpore s strani gospodarstva, kar je tudi pričakovano in razumljivo glede na naravo raziskovanja.

Vrednote so element, ki ga pri znanstvenem razmišljanju in pisanju nikakor ne moremo izpustiti. Skozi čas je v znanosti prevladoval tako imenovani vrednotno nevtralen ideal (Lacey, 2005), ki je poudarjal in zagovarjal objektivnost delovanja $v$ znanosti. $\vee$ tem kontekstu bi tako trditve, ki jih postavimo, lahko bile samo resnične ali neresnične; vse je odvisno od dokazov, ki jih znanstvenik oziroma raziskovalec poda, in nič ni odvisno od vrednotnega prepričanja znanstvenika oziroma raziskovalca (Weber v Kirn, 1988). S tem se predpostavlja, da znanost zgolj navaja opazovana dejstva, brez vrednotnega vpletanja, vse nadaljnje odločitve v povezavi z raziskovanimi dejstvi pa tako niso več v domeni znanstvenika ali raziskovalca, temveč so enostavno prepuščene tistim, ki se ukvarjajo s posledicami ugotovitev.

Takšen pristop k znanosti, ki izključuje vrednotno opredeljevanje znanstvenika ali raziskovalca, je v današnjem svetu raziskovanja nekoliko drugače zastavljen in razumljen. Lacey (2005) tako pravi, da v ospredje stopa nepristranskost, ta je brez vsakega dvoma najvišjega pomena $v$ znanstvenem delovanju. Na tem mestu se postavi vprašanje, ali je znanstvenik oziroma raziskovalec lahko nepristranski, če v svoje odločitve vključuje lastne vrednote.

Douglasova (2000) je do prej omenjenega vprašanja popolnoma jasna, saj poudarja, da imajo vrednote že pred začetkom nekega raziskovanja svojo vlogo, sama pa jih razdeli na tiste, ki imajo neposreden, in tiste, ki imajo posreden vpliv. Tako znanstvenik oziroma raziskovalec sam opredeljuje problem raziskovanja ter izbira metodologijo (Douglas, 2000). Pri tem velja izpostaviti misel Loginove (1990), ki pravi, da so predvsem aplikativno raziskovanje, kjer so naročniki raziskav pogosto podjetja, ki opredeljujejo predmet raziskave (saj jo tudi finančno podpirajo), na eni strani in znanstveniki oziroma raziskovalci na drugi strani v modernem svetu pogosto odvisni od takšne finančne podpore. Ker je raziskovanje $v$ turizmu pogosto odvisno od financiranja s strani gospodarstva, ni imuno za problematiko razkoraka vrednot. Še več: pojavijo se lahko tudi primeri, kjer zatekanje v krog vrednot financerja projekta lahko pripelje do znanstvenih potvorb, kar predstavlja nepopravljivo škodo za raziskovanje.

Douglasova (2000) poudarja, da se vrednotna prepričanja raziskovalca in naročnika ne skladajo vedno. Tako pri sprejemanju (ali zavrnitvi) visoko pomembnost igrajo prav vrednote raziskovalca. Prav tako vrednote, pravzaprav njihova etična komponenta, igrajo odločilno vlogo pri izbiri metodologije raziskovanja. Kot poudarja Douglasova (ibid.), etična sprejemljivost izbrane metodologije direktno vpliva na vse nadaljnje delo znanstvenika ali raziskovalca, saj etične vrednote igrajo legitimno vlogo pri ocenjevanju izbrane metodologije še posebej tam, kjer so v raziskovanje vključeni ljudje ali druga živa bitja. 
V svojem nadaljnjem delu je Douglasova (2009) poudarila, da neposredna vloga vrednot ni vedno sprejemljiva, saj čeprav imajo pri izbiri metodologije svoj neposredni vpliv, pa ga ne smejo imeti pri določitvi metodologije, saj je ta povezana z opredelitvijo problema, ki je bil zastavljen na začetku in je neodvisen od vrednot. Tako lahko rečemo, da vrednote ne smejo določati znanstvenih metod. Temu je mogoče dodati še eno misel, o kateri govorita tako Loginova (1990) kot Douglasova (2009), ki pravita, da bi znanost, če bi jo vodile izključno vrednote, odsevala preveč predsodkov, želja in potreb in bi tako postala nesposobna podati stvarno in zanesljivo razumevanje pojavov ter posledično sveta okoli nas.

V kontekstu debate o vključevanju vrednot $v$ znanstveno raziskovanje se je primerno dotakniti še teme, ki v zadnjem obdobju pogosto zajeda na to področje - govorimo seveda o problemu plagiatorstva. Plagiat je skladno z definicijo Slovarja slovenskega knjižnega jezika (2016) besedilo, ki je prepisano, prevzeto od drugod in objavljeno, prikazano kot lastno. Sama definicija zelo jasno pove, kaj plagiat je, vendar je pomembno razumeti problematiko plagiatorstva v kontekstu znanstvenoraziskovalnega dela. Vsak znanstvenik ali raziskovalec teži $\mathrm{k}$ temu, da bi svetu ponudil neka svoja nova spoznanja, jih z njim delil in s tem doprinesel $\mathrm{k}$ nadaljnjemu razvoju znanosti in posredno tudi sveta. Zato je popolnoma nedopustno in nesprejemljivo prisvajanje neke vsebine kot lastne, če je ta del vsebin nekega drugega avtorja ali avtorice. Naloga znanstvenika ali raziskovalca je nadgrajevanje obstoječih dognanj na podlagi primerno identificiranih virov, ki so jasno označeni. $V$ izogib plagiatorstvu so številne institucije po vsem svetu (tudi Univerza v Mariboru) vzpostavile sisteme preverjanja avtentičnosti besedila posameznika. Dejstvo kljub vsemu ostaja, da popolnega sistema preverjanja (še) ni; tako je še vedno tudi na ramenih vsakega znanstvenika ali raziskovalca breme tega, da dela $v$ skladu $z$ moralnimi in etičnimi načeli.

\section{Viri poglavja:}

Douglas, H. (2000). Inductive risk and values in science. Philosophy of science, 674), 559579.

Douglas, H. (2009). Science, policy, and the value-free ideal. Pittsburgh: University of Pittsburgh Press.

Easterby-Smith, M., Thorpe, R. in Lowe, A. (2007). Raziskovanje v managementu. Koper: Univerza na Primorskem, Fakulteta za management Koper.

Lacey, H. (2005). Is science value free?: Values and scientific understanding. London; New York: Routledge.

Longino, H. E. (1990). Science as social knowledge: Values and objectivity in scientific inquiry. Princeton: Princeton University Press.

Lorber, L. (2003). Prenos znanja in tehnologij kot spodbujevalec regionalnega razvoja. Podravina: časopis za multidisciplinarna istraživanja, 2(3), 76-89.

Slovar slovenskega knjižnega jezika (2016). Plagiat. Pridobljeno iz http://bos.zrcsazu.si/cgi/a03.exe?name=sskj_testa\&expression=ge\%3Dplagiat*\&hs=1, 12. 11. 2016. 
Weber, M. (1988). Smisel vrednotne nevtralnosti socioloških in ekonomskih znanosti. V A. Kirn (ur.), Znanost v družbeno vrednotnem svetu (58-103). Ljubljana: Delavska enotnost. 


\title{
2. POGLAVJE
}

\section{ZNANSTVENO RAZISKOVANJE V TURIZMU}

\author{
Avtor: dr. Borut Vojinović
}

DOI: https://doi.org/10.18690/978-961-286-076-9.2

Turizem kot študijsko področje $v$ Republiki Sloveniji označujemo skladno s klasifikacijo izobraževanja s kodo Klasius P-812, torej sodi pod širše področje, ki je označeno s kodo 8 Storitve oziroma njena podkategorija 81 - Osebne storitve (Statistični urad Republike Slovenije, b. d., str. 38). Takšna opredelitev je sicer izbrana na podlagi razdelitve, ki jo je pripravila Organizacija za ekonomsko sodelovanje in razvoj ( $v$ nadaljevanju OECD) v tako imenovanem Frascatijevem priročniku (OECD, 2015). Klasifikacija Klasius dejansko označuje izobraževalna področja, medtem ko raziskovalna področja pokriva klasifikacija, ki jo predstavlja OECD (2015 in je bila ustvarjena $v$ majhnem kraju Frascati $v$ osrednji Italiji $s$ strani širšega kroga raziskovalcev, danes pa to klasifikacijo poznamo pod imenom priročnik Frascati.

Že več desetletij se $v$ znanstveni skupnosti širijo debate o vpetosti turizma v raziskovanje; tako najdemo na eni strani raziskovalce, ki turizem postavljajo kot popolnoma samostojno disciplino (Leiper, 1981, Tribe, 1997, Leiper, 2000), podajo ji celo poimenovanje »turizmologija « (Jovičić, 1988), in na drugi strani raziskovalce, ki zavračajo ločenost raziskovalnega področja (Echtner in Jamal, 1997). Ne glede na poglede, ki so zelo različni, lahko ugotovimo, da se turizmologija v zadnjem obdobju vedno bolj uveljavlja kot samostojno znanstvenoraziskovalno področje, za katerega je sicer značilna izrazita povezanost s številnimi drugimi področji (Pansiri, 2005; Cardia, 2015). $V$ tem pogledu je tako mogoče govoriti o interdisciplinarnosti. Ta se sicer široko odpira skoraj v vseh znanstvenih področjih. Danes tako skoraj ni znanstvene discipline, ki bi bila popolnoma »čista«, to je značilno tako za naravoslovje kot tudi za družboslovje. $\mathrm{V}$ kontekstu zapisanega bomo tako turizmologijo obravnavali kot samostojno znanstveno področje, vezano primarno na osebne storitve.

Znanstveno raziskovanje $v$ turizmu je torej izrazito interdisciplinarno. Najpogosteje tako lahko najdemo raziskave, vezane na raznovrstne poslovne funkcije (primeri teh so: organizacija dela, trženje produktov, menedžment človeških virov, menedžment destinacij, ekonomski vplivi, finance itd.), gledano nekoliko širše, v turizem vključujemo tudi nekoliko bolj sociološki pogled turizmološkega raziskovanja (primeri tega so: medosebni odnosi, moč in vpliv, politični aspekti itd.), prav tako najdemo tudi nekoliko bolj psihološki pogled turizmološkega raziskovanja (primeri tega so: percepcija posameznika, vpliv medijev, vedenje potrošnikov itd.). Raziskave $\checkmark$ turizmu se tako pogosto zaradi prepleta prej omenjenih področij uvrščajo na področje interdisciplinarnih raziskav, $v$ tem kontekstu se pogosto vključujejo tudi druga raziskovalna področja (primeri teh so: etnografija, geografija, menedžment prireditev, šport in prosti čas itd.), vendar je pri tem treba poudariti pomen osnovnega raziskovanja $v$ turizmu. Tako lahko ostala raziskovalna področja le dopolnjujejo raziskovanje $v$ turizmu, nikakor pa ga ne morejo nadomestiti.

Kot že rečeno zgoraj, je tako pričakovati, da bo večina raziskav $v$ turizmu opravljena $v$ kontekstu osredotočanja raziskovalca na posamezno (posamezne) elemente turizma, zato 
lahko govorimo o tako imenovanih turizmoloških raziskavah. $\mathrm{V}$ njih analiziramo zelo pestro paleto različnih dejavnikov; kot primer navedimo le nekatere: organizacijske oblike $v$ turizmu (organizacija dela), pristope $\mathrm{k}$ prodaji (trženje produktov), zadovoljstvo zaposlenih (menedžment človeških virov), trajnostni razvoj (menedžment destinacij), turistično povpraševanje in ponudba (ekonomski vplivi), donosnost investicij v turizmu (finance) itd. $\mathrm{V}$ okviru sociološkega pogleda na turizmološko raziskovanje tako lahko govorimo o raziskavah; kot primer navedimo le nekatere: komuniciranje s sodelavci/strankami (medosebni odnosi), odnos lokalnega okolja do turizma (moč in vpliv), mednarodni sporazumi/vojne/migrantski tokovi (politični aspekti) itd. $\vee$ okviru psihološkega pogleda na turizmološko raziskovanje lahko govorimo o raziskavah s področij zaznavne vrednosti produkta (percepcija posameznika), ugleda nekega podjetja/organizacije (vpliv medijev), sprememb in navad ljudi (vedenje potrošnikov) itd. To so zgolj nekateri primeri, nikakor pa ne gre omejiti turizmoloških raziskav le nanje, saj vsaka izmed disciplin ponuja še mnogo širši nabor. Ne glede na to, za kakšen tip raziskave se odločimo glede na vsebino, mora vsekakor naslednji korak, odločitev o načinu raziskovanja, temu slediti. Pravzaprav ne glede na to, ali bomo raziskovanje opravili v turizmu ali $v$ kateri drugi panogi, poznamo dva različna pristopa do raziskovanja, in sicer opisni ali deskriptivni pristop in analitični pristop (Zelenika, 2000). V metaraziskavah sicer najdemo še tretji pomemben pristop, tako imenovani evalvacijski pristop, vendar je to raziskovalni pristop, ki velja za zahtevnejšega in zahteva zelo poglobljeno metodološko znanje.

Pri deskriptivnem pristopu gre za opisovanje delovanja, dejstev, sestave ali poteka določenega turističnega pojava in/ali procesa. $V$ okviru deskriptivnega pristopa poznamo tri pomembnejše oblike. Sem sodi postopek klasificiranja oziroma razvrščanja, pri katerem razporejamo izbrane turistične kategorije glede na enake ali podobne lastnosti. Primerjalna ali tudi komparativna metoda predstavlja postopek, s katerim med seboj primerjamo primerljive turistične kategorije (odnose, stanja, pojave itd.). S tovrstnimi primerjavami med turističnimi kategorijami ugotavljamo podobnosti in razlike. $\mathrm{S}$ pomočjo primerjalne metode raziskovalec pride do posplošitev in novih sklepanj. Naslednja metoda $v$ okviru opisnega raziskovalnega pristopa je zgodovinska metoda. Pri njej s pomočjo izbrane pretekle (zgodovinske) dokumentacije spoznavamo, kar se je $\mathrm{v}$ preteklosti dogajalo in zgodilo. Kot zadnjo $\mathrm{v}$ nizu opisnega ali deskriptivnega raziskovalnega pristopa naj navedemo metodo kompilacije, kjer analitikovo sklepanje in/ali opisovanje temelji na tujih ugotovitvah in/ali dognanjih (s pomočjo citiranja vključimo dognanja, rezultate drugih avtorjev, ki so na tem področju pred nami že raziskovali).

Pri analitičnem pristopu je raziskovanje nekoliko drugačno, tukaj ne opisujemo več dejstev, sestave ali poteka določenega turističnega pojava in/ali procesa, temveč to analitično proučujemo. Znotraj analitičnega pristopa $v$ turizmološkem raziskovanju poznamo dve tehniki raziskovanja: tako imenovano indukcijo (induktivni pristop) in dedukcijo (deduktivni pristop).

Deduktivni pristop predstavlja način logičnega sklepanja in ponuja poglobljeno razumevanje pojavov in njihovega ozadja (Žižmond, 1998). V prvi fazi raziskovanja na osnovi postavk deduktivne turizmološke analize, turizmoloških zakonitosti in teoretičnih znanj ugotovimo povezave in odvisnosti med različnimi turističnimi pojavi in procesi, ki jih $v$ naši raziskavi preučujemo. V primeru takšnega sklepanja lahko predpostavimo, da če se denimo ministrstvo za finance odloči za dvig trošarine za alkoholne pijače, ki se prodajajo na trgu (torej tudi v okviru turističnih storitev), bo imel takšen ukrep za posledico zvišanje cen alkoholnih pijač. 
Deduktivno sklepamo, da bi zvišanje trošarin posledično pomenilo zvišanje drobnoprodajnih cen alkoholnih pijač, zaradi česar se bo povpraševanje po teh najverjetneje zmanjšalo.

Induktivno turizmološko raziskovanje: s pomočjo zbiranja in analiziranja zbranih podatkov preverjamo, ugotavljamo pravilnost ugotovitev, ki smo jih zgoraj analizirali z deduktivnim turizmološkim pristopom $\mathrm{k}$ raziskovanju (torej domnevo, da višje trošarine pomenijo višjo ceno izdelka in posledično nižje povpraševanje). $\mathrm{V}$ tem običajno drugem delu raziskovanja $\mathrm{z}$ raznoterimi statističnimi metodami torej preizkušamo z dedukcijo postavljene trditve, jih dopolnjujemo, popravljamo ali spreminjamo. Induktivno turizmološko raziskovanje je torej predvsem empirično, statistično, torej številsko meri. Če nadalje uporabimo prejšnji primer, kjer smo postavili deduktivni sklep, da višje trošarine pomenijo nižje povpraševanje, zberemo podatke o cenah alkoholnih pijač in o količini povpraševanja po teh (pri tem moramo izjemno pozornost nameniti statistični značilnosti ali signifikantnosti izbranega statističnega vzorca in izbrani metodologiji, o čemer se je smiselno posvetovati z mentorjem) v izbranem časovnem obdobju (EPF, 2013a, 2013b in 2013c). Na podlagi zbranih podatkov lahko izračunamo, kaj se je dejansko zgodilo ob dvigu trošarin, in po dobljenem rezultatu (torej z induktivnim pristopom zbranih podatkov) lahko sklepamo, da se, denimo, pri povečanju trošarine na alkoholne pijače za $8 \%$ povpraševanje po alkoholnih pijačah v turističnih storitvah zmanjša za 0,9 \%. Tako smo potrdili našo zgornjo deduktivno trditev, da bi zvišanje trošarin na alkoholne pijače posledično pomenilo zvišanje drobnoprodajnih cen alkoholnih pijač, zaradi česar se bo povpraševanje po teh najverjetneje zmanjšalo.

Opredelili smo torej dve fazi turizmološkega raziskovanja, in sicer induktivno in deduktivno. Kot tretja faza pri večini turizmoloških raziskovanj nastopi ponovno faza deduktivnega turizmološkega raziskovanja, s katero interpretiramo v prejšnji fazi dobljene rezultate, kar lahko pripelje do tega, da bomo oblikovali nove teorije, trditve, hipoteze, ki izhajajo iz prejšnjih.

Seveda niso vsi pristopi potrebni za vse nivoje raziskovanja v turizmu; veliko je odvisno ravno od tega, kako kompleksno se raziskovalec loti raziskovanja nekega problema, a več o tem $\mathrm{v}$ naslednjih poglavjih.

\section{Viri poglavja:}

Cardia, G. (2015). The Four Arrows of Knowledge Applied to Tourism. Revista de Análisis Turístico, (18), 1-10.

Echtner, C. M. in Jamal, T. B. (1997). The disciplinary dilemma of tourism studies. Annals of tourism research, 24(4), 868-883.

EPF. (2013a). Postopki in pravilniki za prijavo teme in zagovor sklepnega dela visokošoolskega strokovnega "Poslovna ekonomija". Pridobljeno iz http://www.epf.um.si/studenti/Vsebina/postopek_diplomiranja_VS.aspx, 24. 11. 2016.

EPF. (2013b). Postopki in pravilniki za prijavo teme in zagovor sklepnega dela univerzitetnega študijskega programa "Ekonomske in poslovne vede". Pridobljeno iz http://www.epf.um.si/studenti/Vsebina/postopek_diplomiranja_UN.aspx, 24. 11. 2016. 
EPF. (2013c). Postopki in pravilniki za prijavo teme in zagovor sklepnega dela študijskega programa 2. stopnje "Ekonomske in poslovne vede". Pridobljeno iz http://www.epf.um.si/studenti/Vsebina/postopek_diplomiranja_BM.aspx, 24.11. 2016.

Jovičić, Ž. (1988). Osnovi turizmologije. Beograd: Naučna knjiga.

Leiper, N. (1981). Towards a cohesive curriculum tourism: The case for a distinct discipline. Annals of tourism Research, 8(1), 69-84.

Leiper, N. (2000). An emerging discipline. Annals of Tourism Research, 273), 805-809.

OECD (2015). Guidelines for Collecting and Reporting Data on Research and Experimental Development. Pridobljeno iz http://www.oecd-ilibrary.org/science-andtechnology/frascati-manual-2015_9789264239012-en;jsessionid=41juba9l5n1jo.xoecd-live-02, 27. 11. 2016.

Pansiri, J. (2005). Pragmatism: A methodological approach to researching strategic alliances in tourism. Tourism and Hospitality Planning \& Development, 2(3), 191-206.

Statistični urad Republike Slovenije (b. d.). Struktura in opisi kategorij klasius-P. Pridobljeno iz http://www.stat.si/doc/klasif/Klasius_P.pdf, 24. 11. 2016.

Tribe, J. (1997). The indiscipline of tourism. Annals of tourism research, 24(3), 638-657.

Zelenika, R. (2000). Metodologija i tehnologija izrade znanstvenog i stručnog djela. Rijeka: Ekonomski fakultet u Rijeci.

Žižmond, E. (1998). Kako nastane pisno delo. Maribor: Ekonomsko-poslovna fakulteta. 


\title{
3. POGLAVJE
}

\section{KORAKI RAZISKOVALNEGA PROCESA}

\author{
Avtorica: dr. Andreja Trdina
}

DOI: https://doi.org/10.18690/978-961-286-076-9.3

Osnovna specifika znanstvene dejavnosti je v sistematičnosti, organiziranosti in kontroliranosti spoznavnega prizadevanja. Gre za prizadevanja, ki želijo prispevati k razumevanju pojavov, s katerimi se ukvarjajo. Znanstveno raziskovanje lahko opišemo kot »racionalno-izkustveno dejavnost, s katero človek na organiziran, sistematičen, nadzorovan in načrtovan način pridobiva novo spoznanje« (Toš in Hafner Fink, 1998, str. IV). Raziskovanje je torej organiziran in sistematičen proces, $v$ katerem igra pomembno vlogo načrtovanje. $\mathrm{V}$ tem se znanstveno raziskovanje bistveno ločuje od vsakdanje radovednosti ali reševanja problemov vsakdanjih situacij. Distinkcija ${ }^{2}$ med njima pa ni nujno toliko $v$ predmetu raziskovanja, kot je $v$ sami metodi. Metodologija se ukvarja s splošnimi pravili oziroma postopki znanstvenega spoznavanja (ibid., str. 13). V vsakokratnem raziskovalnem procesu in v vseh vrstah znanstvenih raziskav moramo nujno slediti metodološkim načelom, saj ta zagotavljajo objektivnost celotnega raziskovalnega postopka in njegovih rezultatov.

V vseh vrstah raziskav, tako aplikativnih kot temeljnih, predstavlja ideja za raziskavo temeljni predkorak $v$ raziskovalnem procesu. Raziskovalna ideja lahko izhaja bodisi iz interesa samega raziskovalca bodisi iz potrebe naročnika raziskave. Raziskovalni proces $v$ osnovi zajema naslednje korake: konceptualizacijo, operacionalizacijo in izvajanje raziskave (Knežević in Bizjak, 2009, str. 16):

1) Konceptualizacija se veže na izbor in opredelitev problema raziskave, definiranje namena in ciljev raziskave, postavljanje hipotez ali raziskovalnih vprašanj.

2) Operacionalizacija zajema definiranje načrta raziskave, spremenljivk in metod za zbiranje podatkov.

3) Izvajanje raziskave pa obsega konkretno zbiranje podatkov (primarnih ali sekundarnih) ter analizo in interpretacijo podatkov.

Kot organiziran in sistematičen proces je torej raziskovanje nadvse kompleksen proces. Kako in kje ga začeti, pa pogosto predstavlja dilemo predvsem raziskovalcem začetnikom. $\mathrm{V}$ nadaljevanju bomo opredelili posamezne korake $v$ raziskovalnem procesu $v$ upanju, da bodo študentom kot začetnikom $v$ raziskovanju $v$ pomoč pri pripravi zaključnih del.

\subsection{IZBOR TEME/PODROČJA RAZISKOVANJA (IN PREGLED LITERATURE)}

Ker je turizem interdisciplinarno področje, s katerim se ukvarjajo različne znanstvene discipline, je raziskovalno delo nujno treba jasno umestiti $v$ specifično disciplinarno področje, $v$ okviru katerega bo izvedeno. Nek predmet preučevanja je namreč mogoče raziskovati iz zelo različnih

2 Distinkcija, iz latinščine (distinctio) - razlikovanje, razločevanje, razlika. 
disciplinarnih izhodišč (na primer turistični razvoj neke destinacije lahko proučujemo skozi različne optike: skozi vprašanje nosilnosti turistične destinacije, povezovanja deležnikov $v$ lokalni skupnosti, skozi odnos lokalne skupnosti do turistov, okoljskih, družbenih in ekonomskih vplivov na gostiteljsko skupnost, organizacijo dela turističnih ponudnikov ali ekonomske kazalnike turistične dejavnosti ipd.). Raziskovanje se začne z izborom okvirne teme, ko svoj interes umestimo $v$ specifično področje raziskovanja (na primer $v$ ekonomijo ali trženje, menedžment prireditev, destinacijski menedžment, sociologijo turizma, psihologijo v turizmu, kulturno dediščino in turizem ipd.), s čimer določimo tudi pojmovni aparat, ki ga bomo uporabili.

Ko opredelimo širše področje raziskovanja, moramo $v$ okviru tega področja določiti ožji problem, ki ga nameravamo raziskati (podoba destinacije, stereotipi v turizmu itd.). Ne moremo namreč proučevati celotnega področja, pač pa moramo jasno zamejiti svoj fokus. Zožitev fokusa predstavlja velik izziv. Pri tem je treba poiskati primerno ravnovesje v razmerju splošnospecifično. Zelo splošne teme za empirično raziskovanje niso ustrezne, osredotočiti se moramo na analizo nekega konkretnega raziskovalnega problema in ga umestiti $v$ okvir dosedanjih spoznanj, ki nam služijo kot teoretski okvir. Obenem naj poudarimo, da gre vsaj na tem nivoju raziskovanja pri zaključnih študentskih delih večinoma pravzaprav za obraten proces, pri katerem se avtor (študent) najprej odloči za nek zelo konkreten problem oziroma predmet raziskave in ga potem umešča $v$ širši prostor $z$ namenom, da pridobi teoretsko in metodološko sprejemljiv okvir.

Pregled literature, v katerem se seznanimo s ključnimi teorijami in koncepti na našem področju raziskovanja ter dosedanjimi študijami in ugotovitvami različnih avtorjev, je nadvse pomemben korak $v$ raziskovalnem procesu in poskusu zožitve našega fokusa. To nam omogoča dober vpogled $v$ aktualne trende $v$ proučevanju teme ter oceno, katera področja so že bolj ali manj raziskana. Za natančno in utemeljeno opredelitev našega problema je torej potreben temeljit študij literature. Pri izboru literature naj se študent orientira po sledečih kriterijih:

- V prvi vrsti naj išče znanstvena dela (monografije, zbornike, članke revij), strokovna literatura naj bo sekundarnega pomena.

- Vključuje naj tako starejša, klasična oziroma kanonična dela, ki predstavljajo mejnike v razvoju nekega področja in so pogosto citirana, kot sodobnejša dela, ki vključujejo novejša spoznanja s področja.

- Že pri izboru in študiju literature naj študent upošteva, da je citiranje po sekundarnem viru (dvojno citiranje) le izjema. Če študentu gradivo ni dostopno, se lahko na ta vir sklicuje izjemoma po sekundarnem avtorju, sicer se pričakuje, da poišče original.

- Pričakuje se seznanjenost s prispevki relevantnih avtorjev s področja, tako tujih kot domačih.

\subsection{OPREDELITEV RAZISKOVALNEGA PROBLEMA (IN NJEGOVE RELEVANTNOSTI)}

Opredelitev problema oziroma predmeta raziskave je, kot že omenjeno, prvi korak v znanstvenoraziskovalnem postopku. »Problem, ki je sprejet kot predmet nekega raziskovalnega dela, je najpogosteje problem, ki povzroča težave $v$ razreševanju vsakdanjih delovnih nalog, kakor tudi $v$ razumevanju ali uporabi neke teorije. Razreševanje tega problema 
pripelje do napredka $\mathrm{v}$ nekem delovnem procesu ali pa do napredka $\mathrm{v}$ teoretičnem razumevanju na nekem področju« (Knežević in Bizjak, 2009, str. 17).

Bistvenega pomena je, da svoj raziskovalni problem dobro utemeljimo oziroma da pojasnimo njegovo relevantnost. Tu se moramo vprašati, zakaj je problem oziroma predmet raziskave pomemben in zakaj ga je sploh treba raziskovati. Z drugimi besedami, utemeljiti moramo, zakaj se je družbeno in znanstveno relevantno ukvarjati z izbranim problemom. Odgovor na to vprašanje je mogoče podati na podlagi pregleda literature in že opravljenih raziskav na obravnavanem področju, kot tudi s pomočjo opisa družbeno-zgodovinskega konteksta, v katerem je predmet preučevanja. Raziskovalne probleme namreč najpogosteje spodbudijo teoretske in metodološke zagate ali družbeno-zgodovinske okoliščine (oziroma kontekst, v katerem je problem in iz katerega lahko pojasnimo potrebo po raziskovanju). Izbran raziskovalni problem lahko tako denimo temelji na neskladju med teorijo in prakso, raziskovalni vrzeli (zapolnjevanju slepih peg in praznin, ki še niso reflektirane) ali nestrinjanju med avtorji. Ko gre za aplikativne projekte, pa je njihova relevantnost še dodatno podkrepljena s praktičnimi interesi gospodarskih ali drugih subjektov. Relevantnost in pomen raziskovalnega problema se torej kažeta skozi njegovo umestitev $v$ aktualen teoretski okvir ali skozi njegovo praktično ali družbeno relevantnost.

Če smo v prvi fazi v funkciji izbire teme in področja raziskovanja pozornost namenili iskanju in pregledovanju velikega števila virov, gre na tej točki za temeljit in kritičen študij literature ter teorij, ki se vežejo konkretno na naš raziskovalni problem oziroma predmet raziskave. Ključno je, da kritično presodimo, kaj je pomembno in kaj ne. Na ta način selektivno in premišljeno oblikujemo teoretični oziroma pojmovni okvir svojega raziskovalnega dela.

Zožitev fokusa in izbiro specifičnega problema raziskovanja nekateri prav zaradi pomembnosti te faze raziskovalnega procesa smatrajo za najkreativnejši del samega raziskovalnega procesa (Vujević v Knežević in Bizjak, 2009, str. 19). Kako je nedvoumna in jasna opredelitev raziskovalnega problema ključen del raziskovanja, lepo ponazarja Einsteinova misel, da je formulacija problema pogosto pomembnejša od rešitve. Problem namreč usmerja raziskovalca skozi raziskovalni proces od začetka do konca in iz tega razloga ga je treba jasno zapisati in natančno definirati ter utemeljiti njegovo relevantnost. Še tako skrbni nadaljnji popravki ali poglobljeni postopki v kasnejših fazah raziskovanja, ki je bilo že v svoji zasnovi zgrešeno, ne morejo odpraviti izhodiščnih napak. »Čim bolj so raziskovalčeve izhodiščne ideje (ali 'analitični okviri') eksplicitne, tem bolj jasno ga usmerjajo v tisto, kar je treba raziskati in kar je varno zanemariti glede na neskončnost informacij, ki jih ponuja vsaka situacija ali primer, « zapiše Ragin (2007, str. 19).

\subsection{NAMEN}

Sleherno raziskovalno delo ima svoj namen, ki odgovarja na vprašanje, čemu bodo rezultati raziskovanja služili. $\mathrm{V}$ osnovi glede na namen ločimo temeljno znanstveno raziskovanje in aplikativno raziskovanje (več o tem glejte tudi v prvem poglavju).

Temeljna raziskava je eksperimentalno ali teoretično delo, s katerim želimo pridobiti predvsem novo znanje o pojavih, ne da bi predvidevali kako posebno uporabo le-tega. Temeljne raziskave se torej večinoma ukvarjajo z izgradnjo, pregledovanjem in izpopolnjevanjem temeljnega znanja in teorij na določenem znanstvenem področju. Rezultati tovrstnih raziskav se navadno 
ne prodajajo, temveč se objavljajo $\mathrm{v}$ znanstvenem tisku ali posredujejo drugim zainteresiranim strokovnjakom. Medtem pa so aplikativne oziroma uporabne raziskave neposredno usmerjene v prvi vrsti k nekemu praktičnemu cilju ali namenu. $Z$ aplikativnimi oziroma uporabnimi raziskavami želimo ugotoviti, kako bi lahko uporabili rezultate temeljnih raziskav ali pa določiti nove metode oziroma načine za doseganje vnaprej opredeljenih praktičnih ciljev (Miklič Milek, 2012, str. 113-114).

Raziskovalno delo oziroma njegovi rezultati so torej lahko namenjeni razširitvi znanstvenih spoznanj ali izpopolnitvi teoretičnih znanj (na način, da podpirajo, dopolnjujejo ali pa celo zavračajo nek del dosedanjega teoretičnega znanja) ali po drugi strani reševanju nekega povsem praktičnega problema na področju dejavnosti $v$ turizmu (denimo $v$ menedžmentu turistične organizacije). Namen raziskave je torej definiran izven projekta, izhaja iz motivacijskih faktorjev tistih, ki so za izsledke neke raziskave najbolj zainteresirani. Jasna in eksplicitna opredelitev namena raziskovanja je pomembna, saj je to pomemben korak $v$ definiciji ciljev raziskovanja (povzeto po Knežević in Bizjak, 2009, str. 19).

\subsection{CILJI}

Na temelju odločitve, čemu bo raziskava služila, je treba opredeliti tudi cilje raziskovanja. Ti so povezani z naravo predmeta raziskave in, kot rečeno, izhajajo iz namena raziskovanja (ki si ga zastavi raziskovalec ali naročnik raziskovalnega dela). Razlikujemo tri možne cilje raziskovalnega procesa: 1) opisovanje ali deskripcija, 2) pojasnjevanje ali eksplanacija in 3) ocenjevanje ali evalvacija, ki jih $v$ nadaljevanju povzemamo po Knežević in Bizjak (2009, str. 20-22):

\section{Opisovanje (deskripcija)}

Raziskava ima lahko povsem opisovalni cilj kot način raziskovanja določenih pojavov, družbenih razmer in odnosov ali obnašanja določenih subjektov. Deskriptivna raziskava omogoči opis področja, ki je predmet raziskave. Tovrstne raziskave so najbolj pogoste na področju turizma iz treh razlogov:

a) področje je relativno novo, posebej ko gre za znanstvenoraziskovalno delo,

b) področje je zelo dinamično in spremembe so zelo pogoste ter

c) rezultati deskriptivnega tipa raziskave se relativno hitro lahko uporabljajo v panogi.

Primer: Predmet opisovanja $v$ raziskovalnem procesu so lahko različni vidiki turistične dejavnosti ali obnašanja turistov, npr. opisati, koliko denarja porabijo turisti povprečno na neki destinaciji, kako potujejo na destinacijo, katere so prvine destinacije, ki jih privlačijo ipd.

\section{Pojasnjevanje (eksplanacija)}

Eksplanatorni cilj odkriva neko vzročnost, kavzalnost v medsebojnem odnosu dejavnikov, ki delujejo na nekem področju. Takšen cilj ima funkcijo pojasnjevanja. Pojasnjuje delovanje spremenljivk $v$ nekem konkretnem okolju in njihovo medsebojno zvezo. Medsebojna pogojenost (kavzalnost) med spremenljivkami je na splošno pogoj za razumevanje nekih procesov, posebno pa za napovedovanje nadaljnjih gibanj na tem področju, kar je v turistični industriji še kako pomemben korak, bodisi da gre za zgolj teoretično delo ali pa za neko analizo, ki bo pripomogla k praktičnim odločitvam menedžerjev. 
Primer: Cilj raziskave je lahko recimo pojasniti, zakaj neka destinacija postaja čedalje bolj zanimiva za turiste; pojasniti razloge za negativen odnos domačinov do turistov na neki destinaciji; pojasniti vpliv zadovoljstva pri delu na motivacijo turističnih delavcev; pojasniti učinek medijev na oblikovanje podobe destinacije ipd.

\section{Ocenjevanje (evalvacija)}

Ocenjevanje je cilj, ki si ga znanstveniki ali praktiki postavijo, kadar želijo ovrednotiti uspeh nekega programa ali politike na področju turistične dejavnosti. Evalvacija kot cilj neke raziskave je zelo kompleksen in večslojen postopek. Ta vključuje kar nekaj faz in vsaka izmed teh je lahko pravzaprav samostojen raziskovalni projekt:

d) evalvacija potreb (definiranje ali ocena potreb kot motivacije za nek proces),

e) analiza samega procesa programa (in ocena evaluabilnosti procesa - ali je program konceptualiziran in operacionaliziran na način, da dopušča zanesljivo in veljavno evalvacijo),

f) analiza rezultatov (outputov) programa oziroma uspešnosti programa (npr. cost-benefit analiza, to je analiza z vidika stroškovne racionalnosti programa) in

g) faza opazovanja in spremljanja programa (angl. monitoring).

Primer: Raziskovanje ima lahko za cilj evalvacijo uspešnosti nekega programa/projekta v turistični dejavnosti. Pri takšnem raziskovanju je treba zastaviti in jasno opredeliti določene kriterije, s katerimi potem ocenjujemo izvedbo ali rezultate aktivnosti nekega programa/projekta v določenem časovnem/geografskem/delovnem območju.

\subsection{OBLIKOVANJE RAZISKOVALNIH VPRAŠANJ, HIPOTEZ ALI TEZ}

Zastavljanje raziskovalnih vprašanj ali postavljanje hipotez oziroma tez je izrednega pomena za pripravo raziskave. Od jasnosti formulacije in precizne opredeljenosti raziskovalnega vprašanja ali hipotez oziroma tez je odvisna celotna raziskava, saj so hipoteze/teze/raziskovalna vprašanja konkretizacije problema raziskave, ki usmerjajo raziskovalca $\mathrm{k}$ določenim ravnanjem. Paziti moramo, da je zapis tako hipotez kot raziskovalnih vprašanj jasen in nedvoumen. Ne glede na to, ali raziskujemo z raziskovalnimi vprašanji ali hipotezami, pa moramo biti pozorni, da so ta verjetna in utemeljena.

Pri kvantitativnem raziskovanju postavljamo hipoteze, pri kvalitativnem pa raziskovalna vprašanja; v primeru teoretskih del, ki ne vključujejo empirične raziskave, govorimo o tezah (več o vsakem od njih v nadaljevanju).

Z raziskovalnim vprašanjem natančno določimo spoznavne cilje raziskovalnega dela. Pri tem ni nujno, da je raziskovalno vprašanje formulirano $v$ vprašalni obliki, lahko je izraženo afirmativno (lahko se denimo vprašamo: Kakšni so motivi za obisk destinacije $X$, ali rečemo: Raziskovali bomo motive za obisk destinacije $X)$. Pri raziskovalnem vprašanju gre torej za vprašanje ali trditev, ki ni neposredno podvržena procesu znanstvenega dokazovanja oziroma preverjanja, pač pa v prvi vrsti predvsem zameji področje raziskovanja in tako usmeri naše raziskovanje. Raziskovalno vprašanje mora biti jasno formulirano in brez zapletenih stavčnih zvez. Če gre za kompleksen problem, se to razreši s postavitvijo več podvprašanj. Splošna raziskovalna vprašanja običajno konkretiziramo $z$ nekaj podvprašanji, ko se temeljiteje seznanimo $s$ predmetom raziskave (povzeto po Hafner Fink in Škerlep, b. d.). 
Če smo pri formuliranju raziskovalnih vprašanj previdni in natančni, pa moramo pri hipotezah biti še nekoliko bolj pozorni, saj zahtevajo empirično preverjanje. Hipoteze so »znanstvene predpostavke, glede katerih raziskovalec meni, da lahko z njimi pojasni določen pojav ali skupino pojavov« (Toš in Hafner Fink, 1998, str. 58). Hipotezo postavljamo na način, da ta formulira specifične lastnosti ali odnose med pojavi in da je te lastnosti oziroma odnose mogoče preveriti. Hipoteze morajo vsebovati le takšne trditve, ki jih je mogoče empirično preveriti. Dobra hipoteza je specifična trditev, ki vodi do novih spoznanj o pojavih, ki jih nameravamo preučevati. Vendar mora biti kljub temu logično umeščena $v$ teoretski okvir raziskave.

Ločimo med deskriptivnimi in relacijskimi hipotezami:

- Deskriptivne hipoteze so opisne hipoteze, ki predpostavljajo določeno lastnost, stanje ali potek pojava. Gre za hipoteze, ki izražajo trditev o obstoju pojava, pogostosti pojava, intenziteti pojava ali o trajanju oziroma nastajanju določenega pojava (Toš in Hafner Fink, 1998, str. 59, 69-70) (npr. Stopnja motivacije med zaposlenimi v hotelski verigi $X$ je visoka./Večina respondentov ima negativno podobo o destinaciji $X$.).

- Relacijske hipoteze so vsebinsko bogatejše, saj izražajo relacije oziroma odnose med pojavi. Usmerjene so zgolj k povezanosti oziroma $\mathrm{h}$ korelacijam med pojavi ali celo $\mathrm{k}$ vzročno-posledičnim odnosom med njimi (Toš in Hafner Fink, 1998, str. 59, 71) (npr. Višje kot je število turistov na destinaciji $X$, višja je stopnja nezadovoljstva rezidentov destinacije s turizmom.).

Oblikovanje hipotez omogoča kontrolo raziskovalnega procesa in usmerjanje našega raziskovalnega dela $\mathrm{k}$ problemu, ki je opredeljen kot predmet raziskave. Zaradi tega morajo hipoteze imeti naslednje značilnosti (povzeto po Knežević in Bizjak, 2009, str. 19):

1. Oblikovane morajo biti tako, da so v skladu s problemom.

2. Biti morajo jasne, nedvoumno postavljene in dovolj natančne (ne smejo biti formulirane tako, da jih je mogoče razlagati na mnogo različnih načinov; odražati morajo naravo nekega pojava, njegov odnos z drugimi pojavi).

3. Način postavljanja mora omogočati njihovo falsifikacijo (formulirane morajo biti tako, da so izključne, le tako je mogoče verificirati njihovo vsebino; hipoteze »jutri bo tukaj deževalo ali pa ne bo deževalo« ne moremo empirično ovreči).

4. Postavljene morajo biti tako, da jih je možno izkustveno (empirično) preverjati (hipoteza, ki bi trdila, da je za zmanjšanje števila turistov odgovoren nek nadnaraven fenomen, je empirično nepreverljiva).

5. Od samega začetka morajo biti verjetne in utemeljene (raziskovanje na temelju neverjetnih in neutemeljenih hipotez je izguba časa).

6. Vsebovati morajo čim večjo eksplanacijsko - prediktivno moč, biti morajo torej kar se da plodne (bolj so plodne, tem bolj je z njimi možno pojasniti večje področje pojava, ki je predmet raziskave).

7. Biti morajo v skladu z že do sedaj oblikovanimi in preverjenimi hipotezami, ki se nanašajo na predmet raziskovanja ( $v$ primerih, kjer to ni mogoče zaradi nezadostne razdelanosti področja raziskave, se je treba čim bolj približati temu idealu). 
8. Biti morajo kar se da enostavne (pri izbiranju med dvema hipotezama se odločimo za enostavnejšo, a je treba tudi tu spoštovati realiteto, saj včasih enostavnejša hipoteza ne pokriva dovolj pomenskega prostora).

Glede na stopnjo splošnosti lahko hipoteze označimo kot splošne, posebne in posamične (Toš in Hafner Fink, 1998, str. 67):

- splošne hipoteze so oblikovane iz najširšega vidika in zajemajo pojav v celoti;

- posebne hipoteze zadevajo ožje dele resničnosti - in sicer glede na trditve, vsebovane v splošni hipotezi;

- posamične hipoteze pa zajemajo le najožje segmente oziroma dele vsebovanega pojava, pogosto zadevajo povsem konkretne situacije ali dogodke.

$\checkmark$ raziskovalnem procesu praviloma najprej oblikujemo splošno hipotezo, ki zajema predmet raziskovanja $\mathrm{v}$ celoti. Lahko pa predmet raziskave nadalje pokrijemo $\mathrm{z}$ več posebnimi hipotezami, ki vsaka pokriva svoj vidik predmeta raziskave oziroma del raziskovalnega problema, ki ga je treba pojasniti. Na Sliki 1 je prikazan odnos posebnih hipotez, ki skupaj pokrivajo celoten krog, ki predstavlja predmet raziskave. Samo sistem hipotez, ki omogoča popolno pokrivanje predmeta raziskave, lahko pripelje do zanesljivih rezultatov. Rečeno drugače, bolj kot je predmet raziskave kompleksen, kompleksnejši sistem hipotez tudi zahteva za svoje pojasnjevanje (povzeto po Knežević in Bizjak, 2009, str. 30).

Slika 1: Odnos hipotez in predmeta raziskave

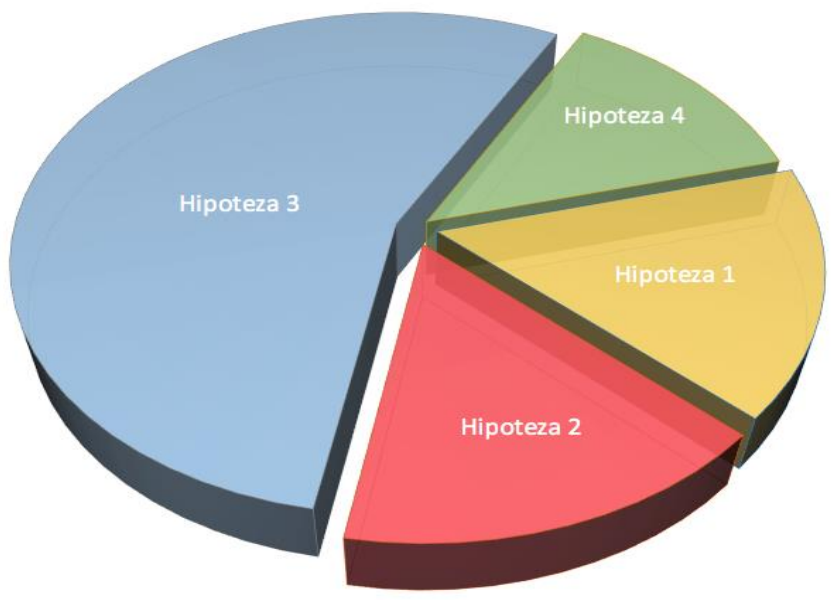

Vir: prirejeno po Knežević in Bizjak, 2009, str. 30

Če je torej hipoteza značilnost empirične raziskave, pa $v$ okviru teoretskih del praviloma govorimo o tezi. Teza je teoretsko trditev, ki se jo »preverja « na ravni teorije na način, da se preverja konsistentnost teze $v$ kontekstu konkretne teorije, teoretskega modela ali na ravni razmerja med različnimi teorijami. Glede formulacije teze veljajo podobne zahteve kot za hipotezo: jasnost, enostavnost, logičnost, preverljivost (tokrat na ravni teorije), netrivialnost itd. (povzeto po Hafner Fink in Škerlep, b. d.). 


\section{Primeri dobrih in slabih hipotez ter raziskovalnih vprašanj}

Hipoteza 1: Slabi delovni pogoji so najpogostejši razlog za nezadovoljstvo zaposlenih.

Hipoteza 1 je primer dobro postavljene hipoteze. Pod pogojem, da izvedemo merjenje na pravilen način, jo lahko empirično preverjamo, hkrati jasno opredeljuje medsebojne vplive in je vseeno povsem enostavna.

Hipoteza 2: Starejši zaposleni imajo več delovne dobe kot mlajši zaposleni.

Hipoteza 2 je na prvi pogled mogoče videti kot povsem dobra, a s potrjevanjem takšne hipoteze potrjujemo nekaj, kar je povsem logično in samoumevno. Hipoteza je sicer preverljiva, a nima pojasnjevalne vrednosti, saj s tem, če jo potrdimo, nismo dokazali nič novega. To je primer, ki mu v metodologiji rečemo »trivialna hipoteza«, ki v kontekstu obravnavane teme predstavlja samoumevno splošno ugotovitev ali zgolj definicijo koncepta, ki je postavljen $v$ središče raziskave.

Raziskovalno vprašanje 1: Katera znanja potrebuje dober menedžer?

Raziskovalno vprašanje 1 je sicer široko zastavljeno, a ob predpostavki, da raziskujemo nek primer (denimo $v$ organizaciji), lahko prek takšnega raziskovalnega vprašanja pridemo do ugotovitev, katera so tista znanja, ki jih bo menedžer potreboval, da bo dobro opravljal delo.

Raziskovalno vprašanje 2: Ali lahko dvignemo ugled organizacije?

Raziskovalno vprašanje 2 je na prvi pogled videti povsem primerno. Toda z vprašanjem $v$ tej obliki bi skozi raziskovanje odgovarjali samo na prvo besedo tega vprašanja, torej besedo »alk«. Beseda »alk< predpostavlja binaren odgovor; nanjo lahko odgovorimo samo $z$ »da« ali »ne«, kar pa ni dovolj za resno raziskovanje. Že samo menjava vprašalnice, npr. z besedo »kako«, pa to vprašanje spremeni $v$ smer tega, da postane povsem pravilno in dobro postavljeno.

\subsection{RAZISKOVALNI NAČRT: IZBOR METODE IN ZBIRANJE PODATKOV}

Odgovor na vprašanje, katero metodo izbrati, je odvisen od raziskovalnega problema in od tega, kaj nas pri njem zanima, od globine in širine problema in od tega, katere podatke potrebujemo za njegovo rešitev (Trunk Širca, Jošt in Skrbinjek, 2012, str. 39). Pomemben del metodološkega načrta raziskave je torej odločitev o tem, $v$ katero raziskovalno paradigmo bo sodila raziskava - ali bo šlo za kvalitativen pristop (npr. poglobljeni intervjuji, opazovanje z udeležbo, diskurzivna analiza itd.) ali za kvantitativno raziskavo (npr. anketna raziskava, analiza vsebine itd.). Kvantitativni pristop se osredotoča na povezave med manjšim številom značilnosti pri velikem številu primerov/enot, medtem ko se kvalitativni pristop ukvarja s povezavami med velikim številom značilnosti v okviru razmeroma majhnega števila primerov/enot (Ragin, 2007, str. 12). Kvantitativno raziskovanje usmerja težnja po posploševanju, kvalitativno pa poglobljeno razumevanje predmeta proučevanja. Za temeljitejšo razmejitev paradigme kvalitativnega pristopa od paradigme kvantitativnega glejte poglavje štiri. Razlike med kvantitativno in kvalitativno metodologijo so predstavljene $v$ Tabeli 1. 
Tabela 1: Kvantitativna in kvalitativna metodologija

\begin{tabular}{||l|l|l||}
\hline & Kvantitativno & Kvalitativno \\
\hline Vloga raziskovalca & Pogled od zunaj & Udeležba v okolju \\
\hline Potek raziskave & Dedukcija & Indukcija \\
\hline Zbiranje podatkov & Standardizacija & Prilagajanje okolju \\
\hline Število opazovanih enot & Veliko & Malo \\
\hline Število opazovanih lastnosti & Malo & Veliko \\
\hline \hline
\end{tabular}

Vir: povzeto po Toš in Hafner Fink (v Trunk Šrca, Jošt in Skrbinjek, 2012, str. 36)

Izbira kvalitativne ali kvantitativne metodologije je v prvi vrsti odvisna od našega problema. Glede na opredelitev raziskovalnega problema se torej odločimo za ustrezno metodo/tehniko zbiranja podatkov.

a) Za kvantitativno raziskavo se torej odločimo, ko $v$ raziskavi opazujemo večje število »objektov« oziroma enot analize in ko se ugotovitve nanašajo na populacijo teh enot analize. $\mathrm{V}$ tem primeru gre običajno za klasičen model preizkušanja hipotez o povezavah med spremenljivkami, torej o povezavah med značilnostmi opazovanih enot. Tipična kvantitativna raziskava je anketna raziskava, ki vključuje dovolj veliko število respondentov, da lahko opravimo statistično analizo zbranih podatkov. Med kvantitativne raziskave uvrščamo tudi analizo vsebine, ko je predmet analize veliko število »objektov« (tekstov oziroma sporočil, kot so časopisni prispevki ali oglasna sporočila $v$ nekem časovnem obdobju ipd.). $V$ vseh primerih gre torej za pristope, ki omogočajo bolj splošne ugotovitve (povzeto po Hafner Fink in Škerlep, b. d.).

b) O kvalitativni raziskavi govorimo v primeru, ko opazujemo manjše število objektov, na katere se nanašajo ugotovitve raziskave. Med kvalitativno raziskovanje uvrščamo intervjuje (strukturirane, polstrukturirane, biografske), fokusne skupine oziroma vodene skupinske razgovore, tudi opazovanje $z$ udeležbo ( $k i$ od raziskovalca zahteva vključitev $v$ raziskovalno okolje in praviloma pomeni kombinacijo več kvalitativnih metod: etnografske metode, poglobljenega intervjuja). V primeru analize tekstov se srečamo s semiotično (analiza znakov) ali diskurzivno analizo (analizo diskurza). Med kvalitativne raziskave bi lahko uvrščali tudi zgodovinsko-primerjalne študije, ko se raziskovalec ukvarja konkretno z analizo nekega zgodovinskega procesa ali dogodka, praviloma na podlagi primarnih (dokumentov ter pričevanja udeležencev) in sekundarnih virov (študij in razprav drugih avtorjev) (povzeto po Hafner Fink in Škerlep, b. d.).

c) Ne gre zanemariti možnosti združevanja metod, torej kombinacije kvalitativnega in kvantitativnega pristopa. Kombinirana uporaba kvalitativnih in kvantitativnih metod postaja vse pogosteje uporabljen raziskovalni načrt, tako na aplikativnem kot tudi na temeljnem znanstvenem področju (glej npr. Lobe, 2006, o triangulaciji in različnih oblikah komplementarnosti kvalitativnih in kvantitativnih metod). Zelo pogosto je glede na naravo raziskovalnega problema smiselno ustrezno združevanje kvantitativnega in kvalitativnega pristopa, četudi gre pri njima $v$ osnovi za povsem različni paradigmi raziskovanja (na eni strani pozitivistično in na drugi strani interpretativno raziskovanje, več v Tabeli 1). Študija primera, pojmovana kot intenzivna študija enega primera, ki nam omogoči poglobljeno razumevanje nekega pojava/enote, tako običajno združuje različne metode zbiranja podatkov (Johansson, 
2003). V okviru študije primera nekega turističnega podjetja lahko tako denimo kombiniramo anketo med zaposlenimi $v$ raziskovanem podjetju, polstrukturirane intervjuje $s$ člani vodstva, statistične podatke o podjetju, analizo dokumentacije, opazovanje $z$ udeležbo na sestankih $v$ podjetju. Združevanje metod lahko poteka tako, da so kvalitativne in kvantitativne metode enakovredne, ali pa je raziskava primarno kvantitativna, medtem ko so kvalitativne metode dopolnilne ali obratno. Pogosti so dvofazni raziskovalni načrti, pri katerih si sledita faza kvalitativnega in faza kvantitativnega raziskovanja v kakršnem koli zaporedju. Običajno izvedemo kvalitativno raziskavo kot pripravo na kvantitativno ali kot pojasnitev izidov kvantitativne (kvalitativna metoda (intervjuji) nam lahko služi kot eksplorativna metoda pri pripravi kvantitativnega merskega instrumenta (anketnega vprašalnika) ali kasneje po opravljeni kvantitativni raziskavi za pojasnitev kvantitativnih rezultatov).

$\checkmark$ raziskovalnem načrtu opredelimo tudi, ali bomo podatke pridobili sami ali bomo uporabili že zbrane. Jasno moramo pokazati, ali gre za samostojno (primarno) empirično raziskavo, kjer raziskovalec sam zbere podatke $\mathrm{z}$ različnimi metodami, ali pa gre za sekundarno analizo podatkov, kjer obdelamo podatke, ki so $v$ različnih oblikah že bili zbrani s kakšnim drugim namenom in so nam dostopni (baze statističnih podatkov, administrativni viri, publikacije, članki, dokumenti). Če se odločimo za primarno (lastno) raziskavo, je treba pripraviti jasen načrt pridobivanja (zbiranja) podatkov: opredeliti metodo (opazovanje, anketa, polstrukturiran intervju, analiza vsebine itd.), definirati populacijo in (po potrebi) način vzorčenja, časovni okvir zbiranja podatkov itd. Odločitev za primarno zbiranje podatkov je praviloma utemeljena na poznavanju in pregledu sekundarnih študij, torej že izvedenih raziskav. Pri premisleku o tipu raziskave je namreč vedno zaželen predhoden vpogled $v$ sekundarne podatke. Naslonitev na sekundarne podatke je lahko ponekod zaradi večje zanesljivosti podatkov tehtnejša kot primarno zbiranje ozkega segmenta podatkov, zaradi običajno kvalitetnejšega vzorčenja pa omogoča tudi bolj poglobljena pojasnila in posplošitve rezultatov, kot je to običajno za primarne raziskave, ki takšne kriterije redkeje izpolnjujejo. Kar želimo poudariti, je, da analiza sekundarnih podatkov nima nič manjšo težo od zbiranja in analize primarnih podatkov, mnogokrat celo zagotavlja večjo zanesljivost in veljavnost ugotovitev (če so podatki ustrezne kakovosti, seveda). To še posebej velja za izvedbo ankete na splošni populaciji, saj je metodološko ustrezna izvedba splošne družboslovne anketne raziskave (oblikovanje vprašalnika, vzorec, zbiranje podatkov) za posameznika zahtevna in zamudna, če ne celo nemogoča zaradi finančnih in časovnih omejitev. Pogosto se $v$ istem raziskovalnem procesu lahko smiselno kombinirata oba pristopa: ob uporabi že obstoječih statističnih podatkov lahko izvedemo samostojne polstrukturirane intervjuje. Primeri primarnih in sekundarnih podatkov so predstavljeni v Tabeli 2.

Tabela 2: Načini zbiranja podatkov

\begin{tabular}{||l|l||}
\hline \multicolumn{1}{|c|}{ PRIMARNI PODATKI } & \multicolumn{1}{c|}{ SEKUNDARNI PODATKI } \\
\hline $\begin{array}{l}\text { Podatki, ki jih pridobimo sami z različnimi } \\
\text { metodami (anketni vprašalnik, intervju, } \\
\text { opazovanje z udeležbo, fokusna skupina, } \\
\text { eksperiment itd.). }\end{array}$ & $\begin{array}{l}\text { knjige, baze statističnih podatkov, statistične } \\
\text { publikacije, uradna poročila, pravni akti, } \\
\text { administrativni viri, dokumenti itd.). }\end{array}$ \\
\hline
\end{tabular}




\subsection{ANALIZA IN INTERPRETACIJA PODATKOV}

Podatke pregledno uredimo, analiziramo in interpretiramo. Rezultate analiz predstavimo v luči raziskovalnih ciljev in $\mathrm{v}$ skladu $\mathrm{z}$ namenom raziskovanja. Vedno jih osmislimo glede na opredeljen raziskovalni problem - kaj nam povedo in o čem lahko iz njih sklepamo. Pri podajanju rezultatov torej nismo zgolj opisni - rezultatov ne nizamo suhoparno ( $v$ obliki deležev/frekvenc odgovorov), temveč jih vselej interpretiramo v luči našega raziskovalnega problema. Na tem mestu predstavimo tudi morebitne nepričakovane rezultate in podamo refleksijo, kaj pomenijo $v$ odnosu do reševanja raziskovalnega problema. Pri analizi in interpretaciji podatkov si lahko pomagamo z različnimi dostopnimi programskimi orodji za obdelavo podatkov (npr. Microsoft Office Excel, SPSS, R-Commander, ATLAS.ti).

\subsection{RAZPRAVA IN UGOTOVITVE}

V razpravi povežemo cilje raziskave $\mathrm{z}$ rezultati, dobljenimi med raziskovalnim postopkom. Rečeno drugače, $v$ ugotovitvah ovrednotimo rezultate analiz glede na opredeljene hipoteze/raziskovalna vprašanja. Skozi razpravo analizirane in interpretirane podatke združujemo $v$ smiselne vsebinske sklope in tako prehajamo iz specifičnega nazaj na splošno. Naše ugotovitve vpenjamo nazaj $v$ teoretični okvir, ko jih povezujemo in primerjamo z že znanimi ugotovitvami ter dosedanjimi raziskovalnimi izsledki.

V zaključku povzamemo ključne ugotovitve raziskave ter posebej izpostavimo morebitne omejitve raziskave - pri tem poskušamo kritično ovrednotiti raziskovalno delo in rezultate dela. Obenem raziskovalec običajno poda refleksijo o doprinosu rezultatov $k$ teoriji in odpiranju novih inovativnih smeri $v$ raziskovanju tega problema - očrta dodatne vidike, ki jih je raziskava odprla, in predstavi potencialne nove raziskovalne smeri na tem problemskem področju.

Ne nazadnje naj dodamo, da se navedene faze $v$ raziskovalni praksi ne odvijajo nujno povsem sukcesivno $^{3}$. Glede na samo naravo raziskovalnega problema namreč pogosto prihaja do njihovega prepletanja: raziskovalec denimo običajno študira področno literaturo kontinuirano vse do konca raziskave; prav tako je možno, da analizo nekaterih podatkov opravi, še preden zaključi zbiranje nekaterih drugih podatkov, hkrati jo lahko $v$ času interpretacije podatkov tudi podrobneje razdela in jo s tem izpopolnjuje.

\section{Viri poglavja:}

Hafner Fink, M. in Škerlep, A. (b. d.). Napotki za prijavo magistrskega dela FDV. Pridobljeno iz http://www.fdv.uni-lj.si/docs/o-fdv/napotki-za-prijavo-teme-mag-dela.docx, 10. 12. 2016.

Johansson, R. (2003). Case Study Methodology. International Conference "Methodologies in Housing Research", Stockholm, 22-24 September 2003. Pridobljeno iz http://psyking.net/HTMLobj-3839/Case_Study_Methodology_Rolf_Johansson_ver_2.pdf, 4. 12. 2016.

${ }^{3}$ Sukcesivno - zaporedno, postopno. 
Knežević, M. in Bizjak, B. (2009). Merjenja in nekateri merski instrumenti v turističnih raziskavah. Portorož: Turistica.

Lobe, B. (2006). Združevanje kvalitativnih in kvantitativnih metod - stara praksa v novi preobleki? Družboslovne razprave, XXII(53), 55-73.

Miklič Milek, D. (2012). Družbeno odgovorno ravnanje in raziskovalna odličnost. 24. forum odličnosti in mojstrstva, Otočec 2012.

Ragin, C. C. (2007). Družboslovno raziskovanje: Enotnost in raznolikost metode. Ljubljana: Fakulteta za družbene vede.

Toš, N. in Hafner Fink, M. (1998). Metode družboslovnega raziskovanja. Ljubljana: Fakulteta za družbene vede.

Trunk Širca, N., Jošt, V. in Skrbinjek, V. (2012). Pisna dela v visokem šolstvu in osnove raziskovanja. Celje: Mednarodna fakulteta za družbene in poslovne študije. 


\title{
4. POGLAVJE
}

\section{OPREDELITEV NAČINA RAZISKOVANJA; MED KVALI- IN KVANTITATIVNIM}

\author{
Avtor: Boris Prevolšek, mag.
}

DOI: https://doi.org/10.18690/978-961-286-076-9.4

Namen raziskovanja, bodisi kvalitativnega ali kvantitativnega, je odkrivanje novih spoznanj, ki prinašajo prispevek k obstoječemu znanju in spodbujajo raziskovalce k novim raziskavam. Raziskovalec lahko za namene pridobivanja novega znanja seže tako po kvalitativnem ali kvantitativnem raziskovanju kot dveh zelo različnih tehnikah zbiranja in obdelave podatkov.

V nadaljevanju bosta predstavljena oba načina raziskovanja, natančneje pa bo prikazan kvalitativni, ki je zaradi poglobljenega razumevanja pojavov in njihovega ozadja vse bolj $v$ veljavi na področju raziskovanja. Medtem ko so $v$ preteklosti prednjačile zgolj kvantitativne raziskave, naraščajo kvalitativne, ki tudi v procesu triangulacije poskušajo zajeti bistvo z vseh možnih zornih kotov.

Kvalitativno raziskovanje, pojem izvira iz latinske besede »qualitas« (kakovost, vrednota, odlika, sposobnost itd.), je raziskovalni pristop, ki pri zbiranju in analizi podatkov uporablja izkustveno besedo in slikovno gradivo. Poudarek je na opisovanju situacij, ki jih proučujemo, in na razumevanju konteksta, v katerem situacije potekajo (Vogrinc, 2008). V ospredju je proučevanje subjektivnih doživetij posameznika. Kvalitativno raziskovanje poteka v naravnih razmerah in ohranja kompleksnost vsakdanjih situacij ter omogoča pridobitev stvarnejših spoznanj (Sagadin, 2001). Kvalitativne raziskovalne metode so zasnovane tako, da z upoštevanjem socialnega in kulturnega okolja pomagajo raziskovalcu razumeti udeležence in predvsem to, kar povedo in kar naredijo (Myers, 2009). Raziskovalec in raziskovani sta tako neločljivo povezana, med njima poteka stalna interakcija, poudarek pa je na induktivnem posploševanju - s posameznega na splošno.

Kvantitativno raziskovanje izvira iz latinske besede »quantitas« (koliko, količina, velikost). Je raziskovanje, za katerega je značilno, da se med pojavi, ki jih raziskujemo, iščejo vzorčnoposledične zveze (Sagadin, 2001). Za to obliko raziskovanja so značilni statistični postopki, krčenje informacij z numeričnimi podatki, pozitivistična filozofija, usmerjenost $v$ rezultat in poudarek na zanesljivosti (Mužić, 2004). Pozitivistična filozofija označuje pogled na svet, ki je zasnovan tako, da je skladen z moderno znanostjo, zavrača religijo, metafiziko in predsodke ter poudarja opisovanje in razlaganje empiričnih dejstev (Vogrinc, 2008, str. 9-10).

\subsection{OPREDELITEV KVALITATIVNEGA RAZISKOVANJA}

Potek kvalitativne raziskave bi lahko opredelili kot vrsto kratkih, zaporednih raziskovalnih ciklov, v katerih si sledijo oblikovanje hipoteze, zbiranje gradiva in analiza, opredelitev problema in formulacija novega problema, ponovno zbiranje gradiva, analiza itd. Tovrstno raziskovanje lahko opredelimo kot sekvenčno raziskovanje, ki sloni na načrtu raziskovalnih dejanj, ki si sledijo v sorazmerno kratkem obdobju, temu pa sledi analiza zbranega empiričnega gradiva 
(Mesec, 1997). Potek kvalitativne analize pa lahko opredelimo tudi kot nelinearen oziroma spiralen oziroma cikličen, takrat ko raziskovalec ne sledi utečenim potem in fazam raziskave, temveč se pri raziskovanju vrača na začetek raziskave in razišče še stranske vidike raziskave, $z$ namenom da ponovi določen del raziskave in pridobi nove podatke (Neuman, 2003). Ob začetku raziskave se tako že izoblikuje neka predstava o pojavu, ki se skozi raziskavo dopolnjuje in tako omogoča postopno širjenje spoznavanja raziskovalca o problemu, kar pojasnjuje Mesec (1997) s pojmom hermenevtičnega kroga, ki ga lahko razložimo s tem, da, ko začenjamo raziskavo, imamo o predmetu raziskave vedno že neko predstavo, naj je še tako preprosta in nedorečena. To izhodiščno razumevanje problema ali predmeta imenujemo predrazumevanje. Mužič (2004) pojasnjuje, da nelinearni potek kvalitativne raziskave temelji na treh etapah, in sicer na reprodukciji podatkov, urejanju podatkov in formulaciji zaključka, za katere pa ni nujno, da si sledijo ena za drugo, ampak se med seboj izmenjujejo in dopolnjujejo. Vprašanja, ki si jih raziskovalci postavljajo v kvalitativnem raziskovanju, so (Myers, 2009): Kaj se dogaja? Zakaj se dogaja? Kako je prišlo do tega? Kdaj se je zgodilo?

Za izvedbo kvalitativnega raziskovanja je pomembno, da raziskovalec upošteva značilnosti slednjega, torej tako primernost uporabe posamezne raziskovalne metode, tehnike zbiranja in analize podatkov kot tudi etična načela. $\mathrm{V}$ okviru svoje raziskave mora jasno opredeliti svoj raziskovalni problem ter natančno in jasno opredeliti raziskovalne cilje. Na osnovi pregleda literature mora tako oceniti, ali obstajajo t. i. raziskovalne vrzeli, ki jih je smiselno raziskovati. Pri modelu svoje raziskave mora izhajati iz določenih filozofskih predpostavk, prav tako pa se mora odločiti, katere raziskovalne metode, metode zbiranja in analize podatkov bo uporabil.

Pri izbiri raziskovalne metode moramo oceniti, ali je izbrana metoda primerna za zastavljeno raziskovalno vprašanje, ali bomo na osnovi metode prišli do želenih rezultatov, kakšni so pogoji in omejitve pri uporabi metode, katere metode so še primerne, kakšno znanje potrebujemo za primerno uporabo metode, ali lahko sočasno uporabimo več različnih metod in ali so te kompatibilne.

Izbiri raziskovalne metode sledi odločitev o metodi zbiranja podatkov, pri čemer se pri kvalitativnem raziskovanju najpogosteje uporabljajo intervjuji, terensko delo (opazovanja) in pregled literature. Metode zbiranja podatkov se lahko uporabljajo ločeno ali pa se jih lahko medsebojno usklajuje. Izbira metode zbiranja podatkov je odvisna od raziskovalne teme, od izbranih raziskovalnih metod in dostopnosti podatkov. Dostopnost podatkov izjemno pomembno vpliva na rezultat raziskave, saj lahko le na osnovi zadostno zbranih podatkov pridobimo odgovore na zastavljena vprašanja. Zbiranju podatkov sledi analiza podatkov, pri čemer se uporabljajo različni pristopi, kot npr. hermenevtična, semiotična, vsebinska analiza itd. Kljub omenjenemu zaporedju korakov pa $v$ procesu raziskovanja poteka nenehna interakcija; tako se lahko raziskovalec tudi vrača k začetnim korakom z namenom, da izpopolni svoj zastavljeni raziskovalni problem oziroma da si zastavi primernejšega.

\subsubsection{METODE KVALITATIVNEGA RAZISKOVANJA}

Raziskovalne metode lahko opredelimo kot strategije povpraševanja, s katerimi prek pridobljenih empiričnih podatkov lažje razumemo in razlagamo proučevan pojav (Myers, 2009). Metode kvalitativnega raziskovanja služijo kot raziskovalno sredstvo, ki omogoča vpogled v mnenja ljudi in okoliščine, v katerih se nahajajo, in tako prinašajo informacije, kot so njihova 
stališča, čustva, mnenja (Easterby-Smith, Thorpe in Lowe, 2005). Vsi podatki, ki so rezultat nekega raziskovalnega dela, so primarni podatki. Sekundarni so podatki, ki jih pridobimo iz drugih že opravljenih raziskav. Kvalitativne raziskave nam podajajo primarne podatke, ti pa so lahko tudi osnova za nadaljnje raziskovanje. Tako s pomočjo primernih metod pridobimo informacije neposredno, hkrati pa zagotavljamo veljavnost, objektivnost in zanesljivost informacij (Radonjič in Iršič, 2006). Med kvalitativnimi metodami raziskovanja bomo predstavili akcijsko raziskovanje in študijo primera, ki se kot metodološka pristopa $v$ kvalitativnem raziskovanju, predvsem v turizmu, uporabljata najpogosteje. Obstaja še cela vrsta drugih kvalitativnih tehnik raziskovanja, med njimi sta na primer etnografija in utemeljena teorija.

Potek akcijskega raziskovanja lahko razumemo kot dvostopenjski proces. Baskerville in Myers (2004) pravita, da proces akcijskega raziskovanja temelji na dveh fazah. V prvi fazi (t. i. diagnostični fazi) poteka proučevanje nekega pojava na osnovi medsebojnega sodelovanja raziskovalca in udeleženca. $\mathrm{V}$ tej fazi se opravi pregled teorij $\mathrm{v}$ povezavi $\mathrm{s}$ proučevanim pojavom. Naslednja faza (t. i. terapevtska faza) predstavi možne spremembe in prouči njihove možne vplive.

Besedna zveza »študija primera« ima več pomenov, pri čemer je najbolj poenostavljen pomen ta, da predstavlja opis posamičnega primera ali situacije, na osnovi katere se lahko oblikujejo splošni zaključki proučevanega pojava. Študija primera se lahko nanaša na družbeni proces, organizacijo ali katerokoli kolektivno družbeno skupino (Myers, 2009). Študijo primera lahko uporabimo $v$ katerikoli fazi raziskovanja. Tako se lahko uporabi na začetku samega raziskovanja, ko je treba razkriti določena dejstva, dejavnike ali odgovoriti na nekatera vprašanja, ki se pojavljajo v podobnih okoliščinah. Študija primera se lahko uporabi tudi po fazi, ko je bila zbrana vsa literatura $v$ zvezi z raziskovalno temo in je treba to pregledati ter preveriti določene teorije, jih razložiti ali medsebojno primerjati. Ključno pri uporabi študije primera ni, kdaj jo uporabiti, ampak kaj z njo proučevati. Študije primera so lahko pozitivistične, razlagalne ali kritične oblike.

\subsubsection{KVALITATIVNE METODE IN TEHNIKE ZBIRANJA PODATKOV}

Kvalitativne tehnike so interpretativne tehnike, s katerimi raziskovalec poskuša opisati, dekodirati, prevesti in drugače odkriti pomen določenih bolj ali manj naravno nastalih pojavov v družbenem svetu (Van Maanen, 1983).

Izbira metode in tehnik zbiranja podatkov je odvisna od izbrane raziskovalne metode, raziskovalne teme in razpoložljivih podatkov. Pri izbiri metod zbiranja podatkov je pomembna tudi seznanjenost raziskovalca z njo. Namreč: le dobro poznavanje tehnik lahko zagotovi njihovo pravilno uporabo. Raziskovalne metode in tehnike nam omogočajo, da zberemo primarne podatke; to so podatki, ki niso bili predhodno objavljeni, ampak so bili pridobljeni neposredno od ljudi oziroma organizacij. Za razliko od omenjenih, sekundarni podatki izhajajo iz predhodno objavljenih knjig, časopisov, člankov itd. Tako že samo zbiranje primarnih podatkov lahko vodi $v$ bogato in kredibilno kvalitativno raziskavo, če raziskovalec obvladuje tehnike zbiranja podatkov. Obstaja več različnih metod in tehnik zbiranja podatkov, pri čemer bomo podrobneje predstavili intervju, opazovanje in terensko delo. Kot tehniko zbiranja podatkov poznamo še uporabo dokumentov. 
Intervjuji se največkrat uporabljajo za študije primera, medtem ko se terensko delo uporablja $v$ primerih etnografije. Kljub temu pa je izbira metod in tehnik zbiranja podatkov stvar odločitve raziskovalca, ki jo sprejme na osnovi predhodnega znanja.

Intervjuji so vsekakor najpomembnejša tehnika zbiranja podatkov na področju poslovnih ved in se uporabljajo tako v pozitivističnih, interpretativnih in kritičnih raziskavah. Intervjuji nam omogočajo, s tem ko poslušamo, spodbujamo in usmerjamo pogovor z intervjuvanci, zbrati bogate podatke od ljudi $v$ različnih vlogah in situacijah (Myers, 2009, str. 121). V osnovi razlikujemo med strukturiranimi, polstrukturiranimi in nestrukturiranimi intervjuji.

Velikokrat se terensko delo poimenuje kot opazovanje $z$ udeležbo in/ali terensko delo in predstavlja način zbiranja podatkov o nekem pojavu s pomočjo neposrednega stika z ljudmi in opazovanjem le-teh v njihovem naravnem okolju. Huges (2005) opredeljuje terensko delo kot opazovanje ljudi na mestu samem, v okolju, v katerem se nahajajo, in z opazovanjem vlog, ki jih opravljajo, na način, da raziskovalec postane del njihovega okolja ter na primeren način posname njihovo obnašanje, pri tem pa ne povzroča škode opazovanim. Wolcott $(2005$, str. 44) dodaja, da je terensko delo način pridobivanja podatkov $z$ neposrednim sodelovanjem raziskovalca $v$ družbenih aktivnostih posameznika ali skupine. $Z$ neposredno osebno udeležbo raziskovalca je zagotovljena določena raven razumevanja ljudi.

Terensko delo se tako bistveno razlikuje od intervjujev, saj omogoča boljše razumevanje pojava. Medtem ko sta za intervjuje namenjena točno določen čas in prostor, kjer poteka, se lahko terensko delo izvede kjerkoli in kadarkoli. Raziskovalec nameni za intervju zgolj nek omejen čas, ki je dosti krajši kot v primeru terenskega dela. V okviru terenskega dela se raziskovalec za daljše časovno obdobje vključi v skupino oziroma organizacijo, ki jo proučuje. Intervjuji so tudi bolj uradni, razumemo jih kot nastop raziskovalca pred intervjuvancem, medtem ko terensko delo poteka $v$ naravnem okolju ljudi, kjer raziskovalec pridobiva informacije skozi neformalne pogovore. Ravno $v$ navezavi s tem so lahko podatki, pridobljeni v okviru intervjujev, dosti bolj uradni oziroma takšni, kot so pričakovani, ne dejanski.

\subsubsection{ANALIZA KVALITATIVNIH PODATKOV}

Naslovitvi raziskovalne teme oziroma problema in izbiri primernih metod raziskovanja ter tehnik zbiranja podatkov sledita analiza in interpretacija kvalitativnih podatkov. Večina analize in interpretacije podatkov se opravi na koncu raziskovanja, ko raziskovalec poskuša iz množice podatkov izluščiti najpomembnejše. Raziskovalec tako poskuša urediti svoje podatke $v$ primerno obliko, ki mu omogoči, da se osredotoči na pomembne vidike svojega raziskovanja. Tako se podatki preoblikujejo $v$ pomembne zaključke, ki omogočajo boljše razumevanje raziskovanega področja in prinašajo nova spoznanja $k$ že obstoječim teorijam oziroma znanju (Myers, 2009). Pri analizi podatkov lahko raziskovalec uporabi različne pristope in jih medsebojno primerno usklajuje. Pri tem se soočamo z različnimi pristopi, ki jih bomo predstavili $\mathrm{v}$ nadaljevanju.

Zagotovo najenostavnejši način analiziranja podatkov je kodiranje, pri katerem uporabljamo različne kode, s katerimi opisujemo oziroma povzemamo nek stavek, odstavek ali celo večjo količino besedila. Miles in Huberman (1994) označujeta kode kot oznake, s katerimi zbranim podatkom med raziskavo pripišemo določen pomen. Analiziranje se tako začne že z oblikovanjem kod, $s$ katerimi uredimo množico podatkov $v$ kategorije in tako zmanjšamo 
količino podatkov, omogočimo njihovo boljšo organizacijo in hitrejšo analizo. Pri kodiranju podatkov bi po mnenju Ryana in Bernarda (2000) morali slediti šestim korakom, in sicer vzorčenju, identificiranju tem, oblikovanju seznama kod, povezovanju kod z besedilom, oblikovanju in preverjanju modelov. $\mathrm{V}$ okviru vzorčenja se identificira besedilo, ki je predmet analize, izpostavi se ključne teme ter se pripravi seznam možnih kod in njihovih definicij. Posameznim kodam se pripiše besedilo, ki jim pripada. Temu sledi vzpostavitev modela, $v$ katerem se preverja, kako so teme, koncepti, prepričanja in obnašanja medsebojno povezani. Vzpostavljen model se nato preveri s pomočjo empiričnih podatkov.

Beležke (beleženje) se velikokrat uporabljajo kot pripomoček pri analiziranju podatkov in predstavljajo osebne zapiske raziskovalca o tem, kaj se med raziskavo dogaja oziroma kako se je lotil le-te. Tako beležke vsebujejo razmišljanja raziskovalca, hkrati pa tudi njegove občutke in početje $v$ času raziskave. Esterberg (2002) prepoznava dva tipa beležk - proceduralne in analitične. Proceduralne beležke se osredotočajo na potek raziskave in tako beležijo, kako se je raziskovalec lotil raziskave in kako jo je izvedel. Takšne beležke omogočajo bogat vpogled v sam potek raziskave. Analitične beležke se osredotočajo na raziskovalno temo, na podatke, ki se zbirajo, in na to, kakšen pomen bi lahko ti imeli. Takšne beležke predstavljajo prvi korak pri oblikovanju zaključnih ugotovitev.

Analitična indukcija je način analize podatkov, pri kateri razvijamo razlage nekega pojava na osnovi enega ali več primerov. Ryan in Bernard (2002) razlagata, da se mora sprva definirati pojav, ki ga želimo razlagati in s kakšnim namenom. Temu sledi preverjanje razlage nekega pojava z večjim številom primerov. Med preverjanjem se tako naša razlaga dopolnjuje z novimi spoznanji, ki jih prinašajo posamezni primeri. Postopek se nadaljuje tako dolgo, dokler se ne vzpostavi neka splošna razlaga pojava, ki velja za vse proučevane primere.

Analiza kvalitativnih podatkov lahko poteka tudi na osnovi niza dogodkov, ki so lahko kronološko razporejeni. Dogodke tako lahko združujemo glede ne neke skupne značilnosti v kategorije; morebiti so to dogodki, ki so nastali v istem časovnem obdobju, oziroma obstaja drug vidik njihove medsebojne povezanosti. Dogodke se lahko opiše $v$ obliki pripovedi ali pa se jih povzame $v$ obliki tabel oziroma časovnih grafov (Miles in Huberman, 1994).

Kritični incident je analiza kvalitativnih podatkov, ki v jedro svoje raziskave postavlja mnenja ljudi o nekih dogodkih oziroma incidentih (Miles in Huberman, 1994). Takšna analiza je nekako skrajšana oblika nizov dogodkov, saj takšen pristop omogoča sistematično zbiranje pomembnih podatkov v povezavi z določenimi dogodki, analizira določene vzorce in omogoča bralcu, da razbere ključne sklepe. Pogosto se tako več različnih incidentov proučuje skupaj in se poskuša identificirati morebitne skupne značilnosti. Čeprav tehnike incidenta izhajajo iz pozitivizma, pa se lahko uporabijo tudi v okviru interpretativnega pristopa (Kain, 2004).

Vsebinska analiza je usmerjena $v$ iskanje pomenov pisnih ali vizualnih virov, kot so časopisi ali oglasi, s tem da členi njihovo vsebino v kategorije (Payne in Payne, 2004). McNabb (2002) poudarja, da je bistvena prednost tovrstne analize podatkov, da raziskovalcu ponuja strukturirano metodo, na osnovi katere lahko analizira vsebino besedila na enostaven, jasen in ponovljiv način. Glavna slabost takšne analize podatkov je, da velikokrat izlušči določene informacije iz konteksta, zaradi česar se velikokrat izgubi pomen celotnega besedila oziroma ga je težko povzeti. Ravno iz tega razloga je vsebinska analiza primerna takrat, ko je pomen nekega besedila zelo močno in jasno poudarjen (McNabb, 2002). Vsebinska analiza je primerna 
za iskanje ponovljenih besed in kako se te spreminjajo skozi čas, zato z njo velikokrat analiziramo zgodovinske trende ali besedila intervjujev.

Analiza pogovora obravnava jezik kot aktivnost ljudi. Za razliko od pisnih virov je za ustne vire značilno, da so neuradni, nestrukturirani in velikokrat slovnično nepravilni. Tema pogovora se velikokrat spreminja, pri čemer se velikokrat predhodne teme sploh ne dokončajo (Myers, 2009). Medtem ko vsebinska analiza stremi k temu, da je pomen besed jasen, analiza pogovora ne zasleduje točno določenih pomenov besed ali idiomov. Vsebinska analiza predpostavlja, da se pomen izoblikuje $v$ fazi izmenjave, zato je koristna za analiziranje sprememb $v$ pomenu, ki se pojavijo med pogovorom. Raziskovalec, ki želi razumeti in razložiti pomen teh pojavov, se mora sam vključiti v verbalne interakcije (Klein in Truex, 1995).

Analiza diskurza se osredotoča na to, kako je določeno besedilo strukturirano, upoštevajoč družbeni kontekst, v katerem je nastalo. Hkrati se osredotoča na jezik, ki ga uporabljajo ljudje v vsakdanjem pogovoru oziroma pri pisanju (Myers, 2009). Poskuša ugotoviti, zakaj je besedilo zapisano, kot je in ne na drugačen način, zakaj se uporabljajo točno določene besede $v$ točno določenem vrstnem redu (Johnstone, 2002). Čeprav obstaja več različnih vrst analiz diskurza, se $v$ največji meri uporablja tista, ki se osredotoča na besedne igre, pri katerih pomembno vlogo igra uporaba metafor, fraz in alegorij. Analiza diskurza poudarja, da je treba besedilo večkrat prebrati in interpretirati (Klein in Truex, 1995).

Analiza metafor omogoča sistematično refleksijo metafor, s katerimi in skozi katere zaznavamo, govorimo, razmišljamo in delujemo. Prvi korak v analizi metafor je, da jih zaznamo $\checkmark$ besedilu. Metafore se pojavljajo takrat, ko se za pomenom besed ali fraz skriva nek globlji pomen in ko njihov pomen izhaja iz neke psihološke ali kulturne izkušnje, ki je velikokrat abstraktna (Schmitt, 2005).

Hermenevtika pomeni učenje o razlaganju, tolmačenju in razumevanju nekega besedila, simbola, znaka. V kvalitativni raziskavi, kot je študija primera ali etnografija, raziskovalec zbere množico podatkov, kot so zapiski, intervjuji, dokumenti, terenski zapiski, zvočni zapisi, opisi dogodkov idr. Raziskovalec mora nato zbrane podatke urediti, interpretirati in razložiti. Ravno pri tem raziskovalcem pomaga hermenevtika, saj jim omogoča analize, skozi katere lahko interpretira in razume pomen besedil. Hermenevtika postavlja v ospredje razumevanje ljudi, torej poskuša doumeti, kaj ljudje govorijo, počnejo in zakaj (Myers, 2009). Omogoča analizo družbenih in organizacijskih situacij na poslovnem področju $v$ globino in se tako uporablja tudi za proučevanje kvalitativnih podatkov na poslovnem področju (in sicer informacijskih sistemov) in v marketingu (Myers, 2009).

Ena pomembnih prednosti semiotične analize $v$ primerjavi $z$ vsebinsko je $v$ tem, da se raziskovalec ne zadovolji s površinskim razumevanjem nekega besedila, ampak poskuša v svoji analizi prodreti pod očitna opažanja in prek njih. Ob tem se je treba zavedati, da tudi raziskovalci znake oziroma simbole vedno interpretirajo različno, zato se je $v$ analizah pogosto treba zateči k arbitrarno določenemu razumevanju pomena (Bryman, 2004, povzeto po Vogrinc, 2008). Myers (2009) kot prednost semiotike izpostavlja spodbujanje raziskovalca, da uporabi različne kategorije podatkov, bodisi v obliki besedila, slik ali zvočnih zapisov, saj ga spodbuja, da dekodira skrivne pomene znakov in simbolov. Kot pomanjkljivost pa avtor navaja pretirano osredotočenost na pomene simbolov in znakov ter ljudem pripisuje pasivno vlogo. Semiotika zahteva tudi precejšnjo kreativnost raziskovalca. 
Narativna teorija predpostavlja, da ljudje oblikujejo in uresničujejo svoja življenja skozi pripovedovanje zgodbe. Veliko teoretikov je poudarilo, da so ljudje brez dvoma bitja, ki pripovedujejo zgodbe (homonarrans). Tako so zgodbe posebna oblika medosebnega komuniciranja v določenem družbenem kontekstu (Sremec, 2009). Narativna analiza se lahko uporablja tudi pri analizi podatkov, pridobljenih na osnovi intervjujev, pri čemer je pomembno, da se od intervjuvancev pridobi informacije, ki podajajo zgodbo, ki mora biti odprta in spodbuja intervjuvanca k novim temam (Chase, 2005, povzeto po Myers, 2009).

\subsection{KVANTITATIVNO RAZISKOVANJE}

Kvantitativne raziskave poudarjajo številke, ki jim pripisujejo vrednosti in na osnovi katerih gradijo svoj teoretični konstrukt ter znanstveno zagovarjajo delovanje proučevanega pojava. Primeri kvantitativnih raziskav so (Myers, 2009):

- ankete,

- laboratorijski eksperimenti,

- simulacija,

- matematično modeliranje,

- statistična analiza,

- ekonometrija.

Kvantitativna raziskava omogoča posploševanje na populacijo z uporabo primernega vzorca ter statističnih metod in se tako velikokrat uporablja, ko želimo raziskati določeno temo pri večjem številu ljudi ali organizacij. Namen raziskave je najti vzorce obnašanja, ki se pojavljajo v različnih situacijah. Slabost kvantitativnih raziskav je, da se med raziskavo izgubi veliko informacij, saj se velik del družbenih in kulturnih vidikov spregleda na račun posploševanja (Myers, 2009).

\subsection{PRIMERI KVALITATIVNIH IN KVANTITATIVNIH RAZISKAV V TURIZMU}

Splošno lahko zapišemo, da je kvalitativni pristop primernejši za zahtevnejše raziskave, ki so kompleksnejše narave, z manjšim vzorcem in temeljijo na opisnih spremenljivkah, medtem ko kvantitativni raziskovalni pristop temelji na numeričnih spremenljivkah.

S kvalitativnimi raziskavami v turizmu proučujemo:

- dimenzije,

- pojavne oblike konceptov,

- raznolikost širine - vrednote (npr. kaj ljudje počnejo, njihovo vedenje),

- vedenje turistov,

- uporabljamo vprašalnice npr. zakaj.

S kvantitativnimi raziskavami pa $v$ turizmu proučujemo:

- odnos, napoved in povezanost med stališči,

- uporabljamo vprašalnico npr. koliko. 


\subsection{VZORČENJE}

Predvsem pri kvantitativnem raziskovanju moramo posebej paziti na širino vzorca (število enot, ki jih zajemamo v raziskavo), da $s$ tem zagotovimo reprezentativnost vzorca, na podlagi katerega lahko pridobljene rezultate posplošimo na celotno populacijo preučevanih enot. Kvantitativno raziskovanje namreč pogosto zahteva ustrezno vzorčenje enot, ker so celotne populacije prevelike za raziskovanje in jih tehnično ni izvedljivo zajeti $v$ raziskavo (primer: lokalno prebivalstvo $v$ raziskavi njihovega odnosa do turistov). Ko je populacija preučevanih enot manjša (npr. direktorji slovenskih naravnih zdravilišč), vzorčenje ni potrebno, saj lahko v raziskovanje zajamemo celotno populacijo.

Pri kvalitativnem raziskovanju, kjer se osredotočamo na proučevanje majhnega števila enot ali le na posamezno enoto (osebo, organizacijo, dogodek, skupino) in jo poskusimo proučiti čim celoviteje, je namesto vzorčenja bolje govoriti o izboru. To pa ne pomeni, da v kvalitativnem raziskovanju način izbora enot, ki so predmet proučevanja, ni pomemben. Ključno je, da je vzorec primeren oziroma relevanten za raziskavo, to pomeni, da bomo z izbranimi enotami pridobili želene informacije, $s$ katerimi bomo lahko odgovorili na naša raziskovalna vprašanja oziroma ustrezno naslovili cilje raziskave (Vogrinc, 2008).

\subsection{RAZLIKA MED KVALITATIVNIM IN KVANTITATIVNIM RAZISKOVANJEM}

Prednost kvalitativne raziskave je, da omogoči raziskovalcu, da zazna in razume, z upoštevanjem okolja, odločitve in dejanja udeležencev raziskave. Določena dejanja in odločitve ljudi je možno razumeti le ob upoštevanju celotnega okolja in okoliščin, ki pomagajo raziskovalcu razumeti določene odzive ljudi. Razlogi, ki govorijo v prid kvalitativni raziskavi, izhajajo iz spoznanja, da se ljudje razlikujejo od naravnega sveta ravno po sposobnosti govorjenja, in ravno skozi pogovor se lahko pridobijo informacije, ki bi se izgubile $v$ množici kvantitativnih podatkov.

Kvalitativno raziskovanje omogoča podrobnejšo analizo posameznega proučevanega pojava ali subjekta. Pri kvalitativnih metodah se vključuje manjše število udeležencev, ki se jim lahko posveti več časa in pozornosti, zato se pridobi več informacij iz dolgoročnega spomina ali iz nezavednega dela zavesti z uporabo projekcijskih tehnik, kot sta igra vlog, interpretacija slik. Velikokrat se tako kvalitativna raziskava izvede za neko novo, še povsem neraziskano področje oziroma za družabne, kulturne in politične vidike ljudi in organizacij. Slabost kvalitativnih raziskav pa je, da je velikokrat nemogoče posploševati ugotovitve, pridobljene na osnovi posameznega primera, na populacijo, kar pomeni, da bi bilo vsakršno sklepanje o populaciji na osnovi vzorca neprimerno (Myers, 2009).

Kvalitativno in kvantitativno raziskovanje uporabljata drugačne pristope, vendar se lahko $v$ raziskovanju med seboj dopolnjujeta, saj za celostno predstavo o nekem pojavu lahko kombiniramo obe tehniki hkrati (Neuman, 2003). Mnenju Neumana se pridružuje tudi Myers (2009), ki prav tako meni, da je uporaba kvalitativnih in kvantitativnih metod potrebna v raziskavah in da sta obe vrsti raziskave lahko znanstveno odlični. Neuman (2013) kvalitativno in kvantitativno raziskovanje opredeli kot proces (triangulacija), pri katerem gre za način gledanja na določen problem $\mathrm{z}$ različnih zornih kotov. Pri triangulaciji metod se tako kvalitativne raziskovalne metode mešajo in dopolnjujejo s kvantitativnimi in obratno. Gre torej za dva različna pristopa, pri čemer se eden zgleduje po metodah naravoslovja, drugi pa uporablja 
metode, ki so značilne za humanistične in kulturološke vede (Mesec, 1997). Triangulacija zagovarja načelo, da bi se moralo $v$ raziskavi uporabiti več različnih raziskovalnih metod, bodisi za zbiranje podatkov oziroma njihovo analizo. Uporaba različnih virov je tako zelo razširjenja; tako raziskovalci pridobivajo informacije bodisi na osnovi pregleda literature, vprašalnikov ali intervjujev. Veliko zahtevnejša je sočasna uporaba različnih raziskovalnih metod za analizo v eni raziskavi, saj se lahko metode med seboj občutno razlikujejo, kar od raziskovalca zahteva širše znanje oziroma poznavanje tako kvalitativnih kot kvantitativnih raziskovalnih metod (Myers, 2009).

Med kvantitativnim in kvalitativnim pristopom torej ni razlike $v$ predstavi, da posamezna raziskava prispeva k širjenju znanja o določenem problemu ali področju. Razlika je $v$ tem, da si pri kvantitativnem pristopu predstavljamo, da posamezna raziskava doda le drobec k širši sliki, ki jo sestavimo na osnovi velikega števila časovno omejenih linearno potekajočih raziskav, medtem ko si pri kvalitativni predstavljamo, da že v okviru ene raziskave, ki jo sestavlja več manjših, postopno razširimo krog spoznanj do te mere, da lahko oblikujemo uporabno teorijo (Mesec, 1997).

\subsection{RAZPRAVA IN UGOTOVITVE}

Pri izbiri analize kvalitativnih podatkov mora raziskovalec preučiti več vidikov. Prvi vidik je vsekakor ta, da mora biti izbrana analiza podatkov za raziskovalca zanimiva oziroma ga mora intelektualno stimulirati, da jo bo tudi zadovoljivo izvedel. Prav tako mora biti pristop k analizi usklajen s filozofskimi vidiki raziskovalca. Tako bo raziskovalec, ki izhaja iz pozitivizma, najverjetneje uporabil vsebinsko analizo ali analitično indukcijo, medtem ko bo raziskovalec, izhajajoč iz interpretativne filozofije, uporabil hermenevtiko, semiotsko ali pripovedno analizo, ter raziskovalec, ki izhaja iz kritičnega pristopa, analizo diskurza. Raziskovalna analiza mora biti prav tako usklajena z izbrano kvalitativno metodo. Torej če uporabimo temeljno teorijo, je neprimerneje nadaljevati kodiranje kot pa uporabiti hermenevtiko ali analizo diskurza. Pomembno je tudi, da se uporabi prava analiza za pravi tip podatkov. Torej če so naši podatki $\checkmark$ obliki posnetega pogovora, je primerna analiza pogovora, pri čemer ta ne pride $v$ poštev, če so naši viri pisni ali slikovni. Prav tako pomemben vidik pri izbiri analize je, da imamo zagotovljeno zadostno znanje in izkušnje, bodisi z naše strani ali strani nadrejenega, saj to zagotavlja, da bo izbrana analiza izvedena v skladu s standardno prakso oziroma na primeren način (Myers, 2009).

V raziskovanju pa se ob omejeni dostopnosti virov in časovnih omejitvah soočamo tudi z omejitvami na strani uveljavljenih etičnih načel. Pri raziskovanju se velikokrat pojavijo moralne dileme, ko poskušamo po eni strani varovati udeležence $v$ raziskavi, po drugi pa opraviti raziskavo z javno objavljivimi zaključki. Raziskovalec mora pri raziskovanju upoštevati številna etična načela, kot so zlato pravilo, poštenost, izogibanje plagiatorstvu, pridobivanje soglasij in dovoljenj za objavo (Myers, 2009). Namen vsake raziskave torej ni le zgolj v pripravi prispevka, ampak v njegovi objavi, bodisi v obliki članka, knjige ali prispevka na konferenci. Tako z znanjem in izkušnjami, ki smo jih pridobili skozi raziskavo, pripomoremo k ozaveščanju ostalih raziskovalcev, ki jim lahko naša raziskava nudi dobro osnovo pri njihovi. Dandanes se še posebej $v$ družboslovnih vedah daje večji poudarek zapisu kvalitativne raziskave kot pa njeni izvedbi. 
Kvalitativno raziskovanje tako na osnovi svojih metod in zbiranja podatkov prinaša možnost poglobljenega razumevanja preučevanega pojava in upoštevanje vidikov in dejavnikov, ki kvantitativnim metodam velikokrat uidejo ravno zaradi krčenja informacij in težnje $k$ posploševanju. Kadar želimo doumeti, razumeti in umestiti pojav $v$ širši kulturni oziroma družbeni kontekst, se $v$ naboru kvalitativnih metod in tehnik zagotovo najde primerna, ki raziskovalcu odpre možnosti raziskovanja in skozi katero lahko ta uspešno in kvalitetno odgovori na svoja raziskovalna vprašanja.

Kvalitativne raziskave so raziskave, ki ponujajo odgovore na splošna vprašanja, in na podlagi njih se izvedejo empirične raziskave. To je po navadi uvodna raziskava, s katero se želi raziskati stališča oziroma predvsem teorijo, kar predhodno omogoča kvantitativno raziskavo. $\mathrm{V}$ kvalitativni metodi so raziskovalci sami in njihovo znanje temeljni standardi. $V$ omenjeni metodi je izjemno pomembna rekonceptualizacija, ki v kvantitativni ni zastopana oziroma ni dovoljena. Ta del je najbolj kompleksen v kvalitativni raziskavi, saj o standardu odloča raziskovalec sam. Raziskovalec sam rekonceptualizira: če mu nekaj ne gre, kar je predvidel oziroma si zamislil, lahko spremeni koncept in ga vzpostavi na novo. To nalogo pa lahko opravi le raziskovalec, ki je odličen metodolog, zato je v kvalitativnem raziskovanju pomembna metodološka izobrazba.

Treba je razumeti, da kvalitativna raziskava ni zgolj pogovor ali intervju, kjer prikažemo, o čem smo se pogovarjali. Je veliko več. Tovrstni raziskovalni pristop je zato zaradi visoke metodološke zahtevnosti primernejši za že izkušene raziskovalce.

\section{Viri poglavja:}

Bastič, M. 2006. Metode raziskovanja. Maribor: Ekonomsko-poslovna fakulteta, Univerza v Mariboru.

Bryman, A. (2004). Social Research Methods. New York: Oxford University.

Chase, S. E. (2005). Narrative inquiry: multiple lenses, approaches, voices. In N.K. Denzin in Y. S. Lincoln (Eds). The Sage Handbook of Qualitative Research (3rd ed., 651-79. Thousand Oaks, CA: Sage.

Easterby-Smith, M., Thorpe, R. in Lowe, A. (2005). Raziskovanje v managementu. Koper: Fakulteta za management.

Maanen, J. V. (1983). Qualitative methodology. Beverly Hills: Sage.

Myers, D. M. (2009). Qualitative research in Business \& Management. Los Angeles, London, New Delhi, Singapore, Washington DC: Sage.

Mesec, B. (1997). Kvalitativna metodologija: izhodišča in načela. V Uvod v kvalitativno raziskovanje $v$ socialnem delu. Pridobljeno iz https:// sites. google. com/site/kvalitativnametodologija/kvalitativna-metodologija/uvod-v-kvalitativnoraziskovanje-v-socialnem-delu-knjiga-1, 7. 1. 2017.

Miles, M. B. in Huberman, A. M. (1994). Qualitative Data Analysis: An Expanded Sourcebook (2nd ed.). Newbury Park, CA: Sage. 
Mužić, V. (2004). Uvod u metodologiju istraživanja odgoja i obrazovanja. Zagreb: Educa.

Neuman, W. (2003). Social research methods: qualitative and quantitative approaches. Boston: Allyn and Bacon.

Radonjič, D. in Iršič, M. (2006). Raziskava marketinga. Ljubljana: GV založba.

Sagadin, J. (2001). Pregledno o kvalitativnem empiričnem pedagoškem raziskovanju. Sodobna pedagogika. http://www.sodobnapedagogika.net/?option=com_content\&task=view\&id=1501\&Ite $\mathrm{mid}=22,6.1 .2017$.

Sremac, S. (2009). Integrativni pristup praktičnoj teologiji: Socijalna konstrukcija konverzijeprimer narativne analize svedočanstva konverzije kod bivših zavisnika. Kairos: Evanđeoski teološki časopis, 3(2), 339-364.

Straub, D., Gefen, D. in Boudreau, M.-C. (2004). "The ISWorld Quantitative, Positivist Research Methods Website". Pridobljeno iz http://dstraub.cis.gsu.edu:88/quant/, 6. 1. 2017.

Vogrinc, J. (2008). Kvalitativno raziskovanje na pedagoškem področju. Ljubljana: Pedagoška fakulteta, Univerza v Ljubljani.

Wolcott, H. F. (2005). Fieldwork vs. (just) being in the field. Fieldwork, 1, 43-58. London: Sage. 



\title{
5. POGLAVJe
}

\section{OSEBNI ODNOSI V ZNANSTVENEM PISANJU}

\author{
Avtor: dr. Marko Koščak
}

DOI: https://doi.org/10.18690/978-961-286-076-9.5

\begin{abstract}
Naučiti učiti se je danes ena od temeljnih kompetenc ljudi. Kompleksna usposobljenost za obvladanje osebnega učenja vključuje sposobnosti odločanja, kritičnosti in samokritičnosti, razvite miselne procese, ohranjeno vedoželjnost, razgledanost, bogat pojmovni svet in zadovoljivo mero osebnega predznanja. Danes se je usposobljenosti za samostojno izobraževanje pridružila tudi digitalna. Ta omogoča, da se študent sam odloča, išče nove poti do znanja (knjiga, časopisni članek, telefonski pogovor z znancem, neposredno opazovanje osebe, ki že zna, arhivi, enciklopedije, internet, konzultacija, poskusi in zmote itd.). Nekateri ljudje vseh teh spretnosti in lastnosti še niso razvili in potrebujejo pomoč mentorja, da ohranijo individualno pot izobraževanja (Krajnc, 2012).
\end{abstract}

\subsection{MENTORSTVO}

Beseda mentor izhaja iz grške legende o starem izkušenem možu Mentorju, ki je bil Odisejev prijatelj. Odisej mu je ob odhodu v trojansko vojno zaupal skrb za dom in vzgojo sina Telemaha. Mentor je bil Odiseju vodnik in vzgojitelj. Beseda mentor torej predstavlja vodjo, učitelja, vzgojitelja, svetovalca mlademu človeku, ki ima manj izkušenj za življenje v družbi.

Mentorstvo je še vedno ena od zelo pogostih oblik izobraževanja. Obdobje študija predstavlja začetek srečevanja študenta s tematiko, ki jo bo med svojim poklicnim udejstvovanjem v takšni ali drugačni obliki srečeval, se torej z njo seznanjal ali jo celo preučeval na precej bolj poglobljen in praktičen način. Diplomsko delo kot zaključek obsežnega študijskega dela zato predstavlja kakovosten vrh študentovega udejstvovanja, ki mu naj predstavlja strokovni izziv, skozi katerega ga običajno vodi in usmerja izbrani mentor. Raven kakovosti izdelanega diplomskega dela je zato delno odvisna tudi od odnosa med študentom in mentorjem. Da bi bil ta odnos čim bolj uspešen in učinkovit, menimo, da je najpomembnejši razvoj pozitivnega odnosa med študentom in mentorjem. Da je mentorstvo uspešno, so potrebni ustrezni začetni pogoji:

- V načelu mentor naj ne bi zavrnil mentorstva, razen če je v veljavi omejitev, koliko mentorstev lahko posamezen mentor sprejme.

- Mentor mora biti prepričan, da bo učenje uspešno, ter brezpogojno verjeti v študentove sposobnosti.

- Mentor in študent se morata osebnostno ujemati vsaj do te mere, da sta si v strokovnem smislu privlačna.

- Med njima mora obstajati medsebojno zaupanje, le tako je mogoča odprta komunikacija. 
Mentor se mora znati približati študentu, se poskusiti vanj vživeti in ga spoznati, da bo znal iz njega potegniti še neodkrite talente in potenciale ter sprostiti vse njegove še neizražene osebne kapacitete. Med mentorjem in študentom po navadi obstaja tankočuten odnos. Svoboda izražanja, napredovanje $v$ spoznanjih študenta na eni in predlogi ter sugestije mentorja na drugi strani ter tudi meje spoznavanja, ki jih postavlja, naj bi bili $v$ mentorskem odnosu $v$ optimalnem razmerju. Kitajski pregovor pravi, da je za človeka največja sreča v življenju, če je kdaj srečal sebi primernega mentorja, ker to zagotavlja, da se bo študent osebnostno razvil in napredoval.

Izobraževanje $v$ sodelovanju $z$ mentorjem je najbolj individualizirana pot do znanja ter sodi med najbolj racionalne in učinkovite oblike izobraževanja. Mentorstvo je dinamičen socialni odnos. Naloge, ki so razdeljene med mentorja in študenta, peljejo k istemu cilju: znanju slednjega. V tem odnosu se tako mentor prilagaja študentu in nasprotno tudi študent mentorju. Mentor skrajša pot do cilja in nadomesti nekatere manjkajoče lastnosti študenta. Pogosto pa do cilja ne more priti študent sam, ker ne zna sprejeti vseh odločitev, kot so: izbira virov, postavljanje kriterijev za zadovoljivo znanje, ugotavljanje napak itd., pa naj bo to 15-, 30- ali 70-letni učenec ali študent. Ob sebi potrebuje mentorja, da skupaj krmarita do cilja. Mentor povezuje in koordinira različne vire znanja in pomaga študentu, da odkriva nove. Pozorno spremlja, kaj študent že obvlada in kakšne so naslednje učne naloge. Ob pomoči mentorja se torej učenec/študent giblje v varnem okolju (Krajnc, 2012).

\subsection{GRAJENJE POZITIVNEGA ODNOSA MED ŠTUDENTOM IN MENTORJEM}

Načinov, kako graditi pozitiven odnos med študentom in mentorjem, je torej veliko, to pa pripomore k splošni pozitivni klimi na fakulteti in uspešnosti njenih študentov. Na podlagi pozitivnega odnosa je verjetnost, da bodo jasno definirani parametri, postavljeni za izdelavo diplomskega dela, tudi učinkovito upoštevani.

Študenti so ljudje in tako je tudi njim - kot vsem ljudem - pomembno, da jih mentor vzame resno, jih vzpodbuja in jim izkaže priznanje za njihove dosežke. Razvoj konstruktivnih odnosov s študenti je proces, ki se izvaja neprenehoma in vključuje vsakodnevne interakcije med študentom in mentorjem. Pri tem je pomembno:

- sporočanje pozitivnih pričakovanj,

- konstruktivna poprava študentovega dela,

- grajenje strokovne samozavesti,

- izražanje zanimanja za študenta in njegovo delo,

- preprečevanje in omejevanje lastnih frustracij in stresa na strani mentorja.

a) Sporočanje pozitivnih pričakovanj študentu: Visoko in pozitivno izražena pričakovanja glede rezultatov študentovega dela prej ali slej pripeljejo do izpolnitve teh pričakovanj. Zato je dobro, da mentor v svoji interakciji s študentom dovolj pozornosti nameni sporočanju ustrezno visokih pričakovanj, tako na akademskem področju kot tudi širše, saj so ta pričakovanja ključna pri izoblikovanju študenta $v$ samostojno mislečega strokovnjaka, ki se bo v prihodnje gibal v strokovnih krogih izven svoje fakultete, vedno pa bo izhajal (tudi) iz znanja, pridobljenega na fakulteti. Pomembno je tudi, da so visoka pričakovanja sporočena vsem študentom, ne le 
tistim, ki predstavljajo najuspešnejši del študentske populacije. To se začne že pri obravnavi študentov na predavanjih in vajah.

b) Konstruktivna poprava študentovega dela: Namen poprave, oblikovanje predlogov in sugestij študentovega dela je $v$ njegovem razmisleku glede opravljene naloge, ugotovitvi razlogov za nujnost le-te in razumevanju njene vsebine tako, da tovrstna dopolnitev v prihodnje ne bo več potrebna. Predlog dopolnitev naj bo strokoven in na noben način usmerjen zoper dostojanstvo študenta. Primerno je, da diskusija o tem poteka na kraju, kjer sta mentor in študent sama, brez nepotrebne publike. Mentor naj zagotovi študentu mentorsko obravnavo, ki bi si jo želel za svojega otroka. Pomembno je, da je diskusija ves čas mirna in konstruktivna ter da se tako mentor kot tudi študent ne prepustita morebitnim frustracijam.

c) Grajenje strokovne samozavesti študenta: Strokovna samozavest je precej podcenjena glede na njen vpliv na uspešen in učinkovit odnos med študentom in mentorjem. Cilj vsakega študenta je oziroma bi moral biti, da na strokovnem področju dosega visoke rezultate, kar posledično vpliva na oblikovanje njegove strokovne, pa tudi širše osebnostne identitete. Naloga mentorja je zato vzpodbujati strokovno samozavest ter jo graditi na strokovnih dosežkih posameznega študenta ali celo skupine študentov na vajah, v letniku ipd. Priznanje študentovim dosežkom se lahko izkaže npr. z razstavo njihovega dela, ustno pohvalo na predavanjih, širjenjem informacij o dosežku drugim študentom in profesorjem, pa tudi s pohvalo študentovega napredka, ne zgolj le odličnega dosežka.

d) Izražanje zanimanja za študenta in njegovo delo: Izražanje zanimanja je eden izmed najučinkovitejših načinov za grajenje pozitivnega odnosa med študentom in mentorjem. Mentor študenta pozdravi, mu iskreno prisluhne in pokaže razumevanje za njegovo videnje postavljenih nalog in dela. Tak pristop vpliva na disciplinirano izvajanje zadanih nalog in sledenje postavljeni metodologiji.

e) Preprečevanje in omejevanje lastnih frustracij in stresa na strani mentorja: Frustracija in stres sta neizogibna pojava pri poklicnem udejstvovanju profesorja oziroma mentorja. Vprašanje torej ni, ali bo mentor postal frustriran in pod stresom, temveč $k d a j$ in kako se bo odzval na to. Znaki vključujejo živčnost in nagnjenost k sprejemanju neracionalnih odločitev. Najprej mora biti mentor sposoben prepoznati signale, ki se sprožijo pri njem osebno, da jih bo lahko uspešno obvladal. Tehnike preprečevanja frustracije in omejevanja stresa naj bodo primerne za vsakega posameznika osebno, kar uspešno deluje pri enem profesorju, ne deluje nujno uspešno tudi pri drugem. Pomembno je tudi, da mentor ustrezno reagira na izraze nagnjenosti, ki jih morebiti kaže študent do njega. Vsekakor mora dosledno analizirati delo študenta in ne njegovega odnosa do njega.

\subsection{PRIPRAVA ZAKLJUČNEGA DELA}

O tej temi je podrobno pisal tudi kolega Vasja Vehovar s Fakultete za družbene vede Univerze v Ljubljani, tako da bodo nekateri pogledi in razmišljanja zelo podobni tistemu, kar je o tej temi napisal tudi on.

Običajno kandidat za diplomsko delo počaka na razpis tem s strani fakultete, na kateri študira. Seveda je možna in tudi zaželena samoiniciativnost, kar v tem primeru pomeni, da obišče mentorja z že izoblikovanim predlogom za temo diplomskega dela pred formalnim razpisom tem s strani fakultete oziroma potencialnega mentorja. $V$ vsakem primeru se študent oglasi pri 
profesorju in izbere oziroma mu profesor - mentor potrdi razpoložljivo in izbrano temo. Pri tem študent profesorja oziroma temo izbere na osnovi nekega subjektivnega kriterija všečnosti teme in morda tudi všečnosti profesorja. V vsakem primeru je smiselno, da z izbiro pohiti, dokler so dobre teme in želeni mentorji še prosti.

\subsubsection{Izbira mentorja za izdelavo diplomskega dela}

Za resno vsebinsko diplomo je tema vsekakor pomembnejša od mentorja. Pomembno je predvsem, da izbrana vsebina študenta zanima in veseli. Kljub temu pa je priporočljivo s strani študenta upoštevati še naslednje:

- Pri starejših študentih/diplomantih naj se pozanima, kako proces diplome poteka pri želenem profesorju, vendar naj to informacijo vzame z veliko rezervo, saj bo verjetno dobil zelo subjektivne informacije. Te bo preveril osebno in v neposredni komunikaciji z mentorjem in si potem ustvaril lastno mnenje, kar je veliko bolj pomembno od prvega. Še bolj pomembno pa je, da ga tema res zanima in da ima dober občutek, ko steče uvodna komunikacija s profesorjem. Vsekakor so razlike, kako se posamezni profesor poglobi v študentovo zadevo in koliko časa si vzame za diskusijo. Na eni strani je večja poglobitev s strani profesorja dragocena in pozitivna, lahko pa včasih preide v pretirane formalistične zahteve. Največje razlike so morda v pogledu sprotnosti odgovarjanja, npr. kako hitro profesor odgovori na elektronsko pošto in kako hitro prebere osnutek. To je za študenta pomembno dejstvo, ki ga mora vzeti v obzir pri dokončni odločitvi in izbiri mentorja. Pred dokončno izbiro mentorja (in teme) je priporočljivo pregledati dosedanje teme potencialnega mentorja in diplomska dela s področja, ki študenta zanima. S tem si ustvari vtis in predstavo, kako bi izgledala njegova diploma, hkrati pa lahko dobi tudi idejo za področje, ki bi ga raziskoval pri svojem delu (Vehovar, 2008).

- Mlajši mentorji, ki še niso bili velikokrat v vlogi mentorja, so večinoma bolj entuziastični in se bodo študentu verjetno bistveno bolj posvetili, imeli bodo več časa in bodo pogosteje dosegljivi. Obenem pa bodo morda tudi bolj natančni in bolj zahtevni. Mogoče pa po drugi strani ne bodo imeli določene širine in izkušenj (morda tudi razumevanja in velikodušnosti), ki pridejo z leti in so posebej dragocene v primeru kakršnihkoli zapletov.

\subsubsection{Izbira somentorja pri izdelavi diplomskega dela}

V primeru specifičnih vsebinskih diplom, ki zahtevajo ozko strokovno znanje, študent ne more pričakovati, da bo profesor obvladoval več področij (npr. profesor s področja marketinga mogoče ne obvlada $v$ celoti področja znamčenja itd.). Podobno so nekatere teme tako kompleksne, da je za kvalitetno obdelavo potrebno sodelovanje dveh specialistov. Dokončno presojo lahko kandidat načeloma prepusti mentorju in se s tem ne obremenjuje. Če mentor oceni, da področja ne more pokrivati, se bo zaradi strokovne in etične odgovornosti odločil za somentorstvo in tudi predlagal primernega kolega. Posebej proaktivni študenti bodo morda že sami prišli s predlogom za somentorstvo, kar je včasih zelo koristno. Vedeti pa mora, da somentorstvo lahko nekoliko zaplete celoten proces in eventualno celo podaljšuje izdelavo diplomskega dela. Po drugi strani pa somentorstvo v večini primerov dviga kvaliteto diplome in bogati izkušnjo študenta. 


\subsubsection{Komunikacija med študentom in mentorjem}

Prvi sestanek je v večini primerov izjemno pomemben, saj definira odnos, motivacijo, (napačno ali pravilno) temo ipd. Na prvem sestanku je priporočljivo s stališča študenta razjasniti predvsem naslednje:

- Koristno je profesorja že na začetku vprašati: koliko časa bo trajal celoten proces, koliko osebnih razgovorov bo potrebnih oziroma je pri njem običajno potrebnih, kje nastajajo pri njem najpogostejše težave, kako je s telefonsko, elektronsko, osebno ali pismeno komunikacijo ter z njegovim odzivnim časom (kaj lahko kandidat pričakuje, kako je z dopusti, z odsotnostjo in kako naj ravna v primeru profesorjeve neodzivnosti)?

- Študent pregleda dosedanje diplome tega profesorja, pozanima se, katera je še posebej dobra. Vsekakor ni slabo, da tako diplomo glede oblike tudi upošteva in se po njej zgleduje, predvsem glede formalnosti. Pametno je pridobiti refleksijo profesorja o tej diplomi, npr. kako jo ocenjuje, je bilo z njo veliko dela, je dovolj kvalitetna, da služi kot model, v katero smer bi jo bilo mogoče nadgraditi ipd. Posamezni profesorji običajno že sami sugerirajo kandidatu primere diplom in dobrih praks iz svojih preteklih mentorstev.

V vsakem primeru pa mora biti študent čim prej - če se da, že kar na začetku - sposoben profesorju $v$ enem stavku jasno artikulirati, kaj je glavni namen diplome, kaj bi z delom rad dosegel in na kakšen način bi se zadeve lotil (Vehovar, 2008).

\subsubsection{Sodelovanje študenta in mentorja}

Kot že omenjeno, je ključni korak v diplomi uvodni sestanek z mentorjem. Nemalokrat je za identifikacijo teme in formuliranje prijave potrebno kar nekaj srečanj oziroma interakcij. Zrela in dobro domišljena tema se nato prelije $v$ prijavo oziroma dispozicijo, ki predhodno rabi še formalno potrditev od mentorja. Pogoste so tudi še 2-3 interakcije, preden je prijava dokončna, kar se vse praviloma opravi ali lahko uredi tudi po elektronski pošti. V določenih primerih - ko zadeve predhodno še niso bile v celoti in dobro dorečene - pa je za samo prijavo potrebno tudi več osebnih pogovorov in usklajevanj.

Ko je delo začrtano (ni nujno, da je tudi že prijavljeno), se začne študent ukvarjati s teorijo in nato z empirijo. $V$ tem okviru je včasih potrebna interakcija z mentorjem, bodisi po elektronski pošti, telefonu (kar je zelo praktično in učinkovito ter se pogosto zanemarja) ali osebno, odvisno od kompleksnosti zadev in načina dela mentorja. Vsekakor pa je osnovno pravilo naslednje: čim so kakršnekoli težave, nejasnosti ali spremembe v načrtu - še več, čim študent začne razmišljati, ali bi bilo morda treba kontaktirati mentorja -, je to znak, da naj mentorja nemudoma kontaktira. Lahko se namreč zgodi, da študent zabrede v napačno smer in s tem izgubi veliko časa.

\subsubsection{Koraki pri izdelavi diplomskega dela}

Število intervencij/interakcij z mentorjem v tej fazi je v zelo širokem razponu, okoli polovica diplom jih pravzaprav potrebuje zelo malo ali celo nič, nekatere pa seveda ustrezno več. Običajno pa so $v$ tem procesu vsaj trije mejniki, ki terjajo mentorjevo povratno informacijo: 
1. Ko je znaten del teorije ali empirije predelan (npr. nekaj deset ur), je smiselno čim prej pripraviti prvi »delovni osnutek« na nekaj straneh:

- »delovni osnutek« (1-2 strani opisa vsebine, seveda le, če se je bistveno spremenila od prijave oziroma dispozicije ali pa če prijave še ni bilo - sicer vse to ni potrebno, saj je vključeno že v prijavo),

- prvi osnutek uvoda (vsaj stran ali dve, da se vidi, kako študent piše; v izjemnih primerih se lahko - vendar po dogovoru - napiše tudi več, npr. cela teorija),

- kazalo in literatura, kar je lahko enako kot v prijavi oziroma dispoziciji, če obstaja in je bilo to sprejeto s strani mentorja.

Mentor nato vse to pregleda in se odzove. Če ni zapletov, na tej točki ni potrebna posebna (osebna) reakcija mentorja in običajno zadošča elektronska potrditev, da je zadeva $v$ redu in da naj študent nadaljuje delo.

2. Naslednji ključni korak je cca 10-30 strani teksta, ki ga je dobro spisati takoj, ko študent predela dovolj teorije ali empirije in je jasno, da nadaljnje poglabljanje tega uvodnega dela diplome ne bo več bistveno spreminjalo. V primeru velike samostojnosti, medsebojnega poznavanja in zaupanja ter dobre izkušnje s točko 1 lahko študent spiše tudi že kar celotno diplomo (kar je sicer bolj redek slučaj in ga načeloma mnogi mentorji odsvetujejo). Navedeno besedilo je pomembno, ker se dokončno vidi, kako študent piše, mentor lahko oceni analitičnost in širino ter morebitne vsebinske težave diplomskega dela (odvisno od samostojnosti, zrelosti, artikuliranosti in zahtevnosti teme). Nato lahko študent brez dodatnih interakcij izdela celoten osnutek, lahko pa $v$ tem procesu mentor oceni in predlaga, da bo treba izvesti bolj ali manj temeljite interakcije - elektronske ali osebne. Na tej osnovi se lahko do končnega teksta izmenja še več delnih osnutkov. $V$ primeru kompleksnejših zadev, kjer je potrebna interakcija, je daleč najbolj učinkovito, da se osnutke pogleda in komentira v živo, na osebnem srečanju. Pri osebnem razgovoru se namreč lahko dodatno pojasnijo argumenti ene in druge strani in je potem končna odločitev o tem, kako naprej, bolj usklajena in s konsenzom med študentom in mentorjem. Obširnejše komentiranje diplome (npr. v obliki »sledenja sprememb«) za vsebinske komentarje po navadi ni najbolj učinkovito (primerno je predvsem za formalne, jezikovne pripombe), saj ni interakcije, zato mentor včasih porablja čas dvakrat, najprej da bere in označuje, nato pa to v osebni interakciji komentira oziroma interpretira. Če so stvari dobro koncipirane, mentor na tej točki nima večjih komentarjev (Vehovar, 2008).

3. Končni osnutek nastane lahko zgolj na osnovi ene povratne interakcije uvodnega osnutka (2), lahko pa so - kot navajamo zgoraj - potrebne tudi vmesne interakcije (elektronske, telefonske, osebne). Če je tema dobro definirana, študent pa je samostojen in ima dobre delovne izkušnje, vmesnih interakcij ni ali pa so minimalne. $V$ vsakem primeru mentor sistematično pregleda končni osnutek. Če ima minimalne jezikovne pripombe, morda zadoščajo komentarji v besedilu, v primeru kompleksnih vsebinskih zadev pa je smiselno, da se pregled opravi $v$ živo. Pri enostavnih zadevah lahko izkušen mentor opravi branje kar skupaj $\mathrm{s}$ študentom, sicer pa ga prebere predhodno in nato na sestanku posreduje komentarje. Če je komentarjev malo ali nič, je proces pisanja zaključen, sicer so potrebne interakcije, dokler mentor ne odobri dela (Vehovar, 2008). 


\subsubsection{Trajanje procesa in število interakcij z mentorjem}

Trajanje procesa in število interakcij z mentorjem sta seveda odvisna od več dejavnikov: od izbrane teme, strokovne literature, ki je na voljo, kvalitete in doslednosti pri upoštevanju mentorjevih navodil s strani študenta, kvalitete in poglobljenosti korektur mentorja, časovne razpoložljivosti itd. $\mathrm{V}$ pogledu trajanja se velja seznaniti tudi $z$ uradno določbo pravilnika Fakultete za turizem o tem, do kdaj je mentor dolžan besedilo diplome pregledati ter podati pripombe. Seveda je vedno bolje zadeve prediskutirati in se obojestransko dogovoriti za razumne roke, ki omogočajo optimalno izvedbo zastavljenega dela. Mentor sicer načeloma lahko (s pisno utemeljitvijo) sodelovanje tudi zavrne zaradi drugih razlogov. Enkrat v procesu diplomiranja pa lahko sodelovanje $z$ mentorjem prekine tudi študent in nato poda novo prijavo z drugim mentorjem.

\section{Viri poglavja:}

Krajnc, A. (1979). Metode izobraževanja odraslih. Ljubljana: Delavska enotnost.

Krajnc, A. (2006). Kdo so bili moji mentorji? Kdo mi je lahko mentor?. Andragoška spoznanja, 13(4), 31-39.

Krajnc, A. (2012). Individualizacija izobraževanja vodi v mentorsko gibanje Znaš, nauči drugega. Andragoška spoznanja, 18(2), 19-28.

Vehovar, V. (2008). Priporočila za diplomsko delo. Pridobljeno iz http://vasja.ris.org/c/374/Priporocila_za_pisanje/?preid=2, 23. 11. 2016. 



\section{POGLAVJE}

\section{JEZIK IN SLOG PISANJA}

Avtorica: Barbara Pavlakovič

DOI: https://doi.org/10.18690/978-961-286-076-9.6

Poglavje o jeziku in slogu pisanja govori predvsem o tem, kaj je v znanstvenem pisanju $v$ turizmu jezikovno primerno, lepo in dobro. Jezikoslovec Jože Toporišič (2008, str. 23) je zapisal, da je sporočilo dobro takrat, ko je »[...] resnična ali umišljena predmetnost našla svojo najpopolnejšo ubeseditev, tj. kadar smo jo z jezikovnimi sredstvi zajeli $\mathrm{v}$ čim popolnejši tipičnosti [...]«. Kar pomeni, da je sporočilo najbolj učinkovito prav takrat, kadar prejemnik sporočila prepozna pravi namen sporočanja. Zato, da pripravimo tako besedilo, je seveda potrebno nekaj vaje ter razvit jezikovni čut. Kot ga opisuje Toporišič (ibid.), je to podzavestno obvladovanje meril in pravil o uporabi jezikovnih sredstev. $V$ nadaljevanju poglavja navajamo nekaj smernic, kako primerno uporabljati jezik za znanstveno sporočanje v turizmu.

\subsection{SPLOŠNE LASTNOSTI ZNANSTVENEGA PISANJA}

Seminarske naloge in zaključna dela sodijo glede na vrsto besedil $v$ strokovna besedila (Gomboc, 2009, 148). Z ostalimi strokovnimi besedili jim je skupno to, da so namenjena prejemnikom, ki se zanimajo za predstavljeno vsebino ali pa se tudi sami ukvarjajo z obravnavano tematiko. Druga značilnost je ta, da ta besedila pripravijo strokovnjaki na posameznem področju, ki pri svojem sporočanju uporabljajo veliko strokovnih izrazov in terminov. Kar pomeni, da prejemnik za razumevanje besedila potrebuje nekaj predznanja.

Sicer lahko strokovna besedila delimo na znanstvena in poljudnoznanstvena besedila (ibid., str. 150). Seminarske naloge in zaključna dela umeščamo med znanstvena strokovna besedila. Kot je značilno za znanstvena besedila, pri pisanju seminarskih nalog in zaključnih del tako uporabljamo bolj zapleteno izražanje, definicije in strokovne izraze. Značilno za tako pisanje je tudi neglagolsko izražanje, raba trpnika ter natančno in enopomensko opisovanje ugotovitev. Pri tem je pomembno objektivno stališče avtorja.

Objektivnost besedila izražamo tudi skozi uporabo primerne glagolske oblike (glagol kot beseda, ki poimenuje dejanje, stanje, dogajanje, zaznavanje, obstajanje) (ibid., str. 93). Da zagotovimo objektivnost, nalogo pišemo $v 1$. osebi množine. Primer vseh oseb in števil glagolskih oblik je prikazan v Tabeli 3. 
Tabela 3: Osebe in števila glagolskih oblik

\begin{tabular}{||c|c|c|c||}
\hline Oseba/število & Ednina & Dvojina & Množina \\
\hline 2. oseba & $\begin{array}{c}\text { Jaz } \\
\text { ugotavljam. }\end{array}$ & $\begin{array}{c}\text { Midva/midve } \\
\text { ugotavljava. }\end{array}$ & $\begin{array}{c}\text { Mi/me } \\
\text { ugotavljamo. }\end{array}$ \\
\hline 3. oseba & $\begin{array}{c}\text { On/ona/ono } \\
\text { ugotavlja. }\end{array}$ & $\begin{array}{c}\text { Onadva/vidve } \\
\text { ugotavljata. } \\
\text { ugotavljata. }\end{array}$ & $\begin{array}{c}\text { Vi/ve } \\
\text { ugotavljate. }\end{array}$ \\
\hline ugotavljajo. \\
\hline
\end{tabular}

Seminarske naloge in zaključna dela pišemo v slovenskem jeziku (izjeme, ko se lahko pišejo v tujem jeziku, so opredeljene v Pravilniku o postopku priprave in zagovora diplomskega dela na dodiplomskem študiju Fakultete za turizem UM ter v Pravilniku o postopku priprave in zagovora magistrskega dela na podiplomskem študiju Fakultete za turizem UM). Pri pisanju znanstvenega besedila se izogibamo uporabi tujk predvsem tam, kjer je v uporabi priznan slovenski izraz. Če je le možno, poiščemo ustrezne izraze v svojem jeziku. Toporišič (2008, str. 25) navaja, da uporaba tujk ne pripomore k pestrosti ali večji razumljivosti besedila. Lahko pa po drugi strani uporaba domačih izrazov pripomore $h$ krepitvi izrazoslovja in strokovnih besed $v$ domačem jeziku, kar posledično krepi samo turistično stroko.

Glede na to, da v turizmu deluje širok spekter zaposlenih z različno izobrazbo, je izredno pomembno, da skrbimo za izobraževanje tudi na področju razvijanja intelektualnega znanja. Korak k temu je učenje znanstvenega pisanja in $s$ tem širjenje znanj s področja turizma. Znanstveno pisanje $v$ turizmu sledi trem osnovnim navodilom o pisanju. In sicer naj bo pisno delo (Sternad, Boršič in Tominc, 2013, str. 55):

- jasno (rdeča nit besedila mora teči gladko in smiselno od začetka do konca dela);

- jedrnato (besedilo naj bo strnjeno brez ponavljanja že napisnega in brez odvečnih, vsebinsko nepomembnih dodatkov);

- povezano (vsebino besedila se piše povezano, pri čemer si odstavki in poglavja logično sledijo ter nadaljujejo predstavljeno misel, ne navaja se samo nepovezanih alinej).

Besedilo pišemo argumentirano in podkrepljeno s citati. Vendar pa samo naštevanje citatov avtorjev ni sprejemljivo - vezni členi v besedilu so naše misli, povezovalna beseda, razmislek. Besedilo razdelimo v poglavja in podpoglavja, ki so smiselno zaključene celote iz več odstavkov (odstavki so smiselno zaključene celote več stavkov). Poglavje je lahko sestavljeno iz več podpoglavij, ki so dolga vsaj polovico strani A4. Če je obseg poglavja manjši, moramo razmisliti, ali sploh potrebujemo novo poglavje ali pa to vsebino lahko vključimo $v$ drugo poglavje. Besedilo sledi razvoju predstavljene ideje, zato se mora vsebina poglavja ujemati z naslovom poglavja.

Seminarske naloge ter zaključna dela so javna dela, kar pomeni, da so namenjena in dostopna širši javnosti. Zaključna dela poiščemo v fakultetni knjižnici, seminarske naloge pa so pogosto narejene $v$ sodelovanju z organizacijo, ki želi spoznati vpogled na svoje delo s strani študentov. Ker so pisna dela dosegljiva javnosti, moramo poskrbeti, da so tudi jezikovno korektna. Kar 
pomeni, da moramo pri pisanju upoštevati pravopis in slogovna pravila. $\mathrm{V}$ nadaljevanju poglavja bomo predstavili nekaj pogostih pravopisnih zagat.

\subsection{LOČILA}

Ločila so pomemben del uporabe jezika, saj povezujejo besede, besedne zveze, dele povedi ali povedi med seboj, označujejo pa tudi potek besedila in označijo pomen konca povedi (Gomboc, 2009, str. 120). Ločila tako ločimo na kočna in nekončna. Končna ločila so pika (.), klicaj (!) in vprašaj (?), ki so levostična ločila (med besedo in ločilom ni presledka). Med končna ločila sodita še tropičje (...) in pomišljaj $(-)$, ki sta nestični končni ločili (med besedo in ločilom je presledek). Pri znanstvenem pisanju se izogibamo uporabi klicaja, tropičja in pomišljaja, saj kot ločilo nosijo tudi čustveno konotacijo oziroma kažejo na nedokončano misel, ki se je zaradi objektivnosti pri znanstvenem pisanju izogibamo.

\section{Primer:}

- PIKA: Turizem je pomembna gospodarska panoga.

- KLICAJ: Pozdravljeni!

- VPRAŠAJ: Kako bi lahko razložili povezanost med spremenljivkama?

- TROPIČJE: Tega nam ni uspelo ugotoviti ...

- POMIŠLJAJ: Ko bi vedeli -

Med nekončnimi ločili so dvodelna ločila, kot so pomišljaj (-), narekovaj (» «) in oklepaj ( ). V skupino enodelnih nekončnih ločil sodijo vejica $($,$) , podpičje (;)$, dvopičje $(:)$, tropičje $(. .$.$) ,$ pomišljaj (-) in vezaj (-). Narekovaj in oklepaj pišemo stično z besedami (prvi del desnostično, drugi del levostično). Vejica, podpičje in dvopičje so levostična ločila. Tropičje in pomišljaj sta nestični ločili. Izjema pri pomišljaju (ibid., str. 125) je njegova uporaba namesto predlogov od in do, ko postane pomišljaj obojestransko stično ločilo. Druga izjema pa je uporaba v pomenu minus, ko pomišljaj postane desnostično ločilo. Vezaj kot krajša črtica je največkrat obojestransko stično ločilo, ki se ga piše v nekaterih tujih imenih in besednih zvezah, med dvema priimkoma ter med obema deloma dvojnega zemljepisnega imena (Dobrovoljc in Jakop, 2011, str. 108)

\section{Primer:}

NAREKOVAJ in OKLEPAJ: Kot navaja definicija turizma: »Turizem je celota odnosov in pojavov, ki nastanejo zaradi potovanja in bivanja oseb, za katere kraj nastanitve ni niti glavno niti stalno bivališče niti kraj zaposlitve« (Mihalič, 1998, str. 14).

VEJICA: Po statističnih podatkih je bilo v letu 2015 največ nočitev v občinah Ljubljana, Piran, Bled, Kranjska Gora in Brežice.

DVOPIČJE in PODPIČJE: Da je prehrana zdrava, mora biti:

- uravnotežena, tako da vsebuje optimalno količino hranil;

- varna, tako da ne zastruplja organizma;

- varovalna, tako da varuje pred nastankom civilizacijskih bolezni. 
POMIŠLJAJ: Zgodovina naše občine je zelo bogata - prve zametke turizma lahko najdemo že v 18. stoletju. // Muzej ima dolg obratovalni čas, saj je odprt 8.-20. ure. // Zime na Finskem so izjemno ostre, običajna temperatura sega do $-20^{\circ} \mathrm{C}$.

VEZAJ: V Sloveniji se je železniška mreža razvila v času Avstro-Ogrske. Obiskali smo nemško zdraviliško mesto Baden-Baden. Nismo načrtovali, da bi se ustavili v Šmarju - Sapu.

\subsection{VELIKA IN MALA ZAČETNICA}

Načeloma pišemo besede $z$ malimi črkami, veliko začetnico uporabimo $v$ naslednjih (najbolj pogosto uporabljenih) primerih (Gomboc, 2009, str. 72):

Kot prvo besedo $v$ povedi: Turistična panoga je $v$ porastu.

Za začetek citirane povedi oziroma premega govora: Kot navaja definicija turizma: »Turizem je celota odnosov in pojavov, ki nastanejo zaradi potovanja in bivanja oseb, za katere kraj nastanitve ni niti glavno niti stalno bivališče niti kraj zaposlitve« (Mihalič, 1998, str. 14).

Za lastna imena ali imena bitij: David Novak, Tjaša, Slovenija, Zdravljica, Zemljan ...

Za svojilne pridevnike iz lastnih imen: Davidov, Tjašin, Slovenčev ...

Lastna imena so lahko osebna, stvarna in zemljepisna imena. Med osebna imena sodijo imena ljudi in živali, priimki in vzdevki (David Novak, kuža Fifi, Rdeča kapica), imena bajeslovnih bitij (Bog, Alah, Apolon) ter imena prebivalcev (Ljubljančan, Slovenka, Azijec).

Stvarna imena uporabimo za poimenovanje podjetij, ustanov, skupin, knjig, umetniških del, lokalov, vozil, blagovnih znamk itd. (Gomboc, 2009, str. 74). Prvo besedo stvarnih imen pišemo $z$ veliko začetnico, vse naslednje pa z malo (izjema so besede, ki so lastna imena). Med stvarna imena sodijo tudi poimenovanja turističnih objektov in muzejev, kot so imena hotelov, počitniških domov, muzejskih objektov in njihovih izpostav (Dobrovoljc in Jakop, 2011, str. 77).

Primer: Slovenska turistična organizacija, Mestni muzej Ljubljana, Koča pri Triglavskih jezerih, Grand hotel Bernardin, Republika Slovenija, revija Turizem, Dnevi piva in cvetja itd.

Enobesedna zemljepisna lastna imena se pišejo z veliko začetnico (Posavje, Avstrija, Ljubljana), pri večbesednih pa sledimo pravopisnim pravilom (Gomboc, 2009, str. 73). Pri tem jih delimo na naselbinska in nenaselbinska imena. Naselbinska označujejo imena mest, trgov, vasi in zaselkov. Tu so vse besede zapisane $z$ veliko začetnico, razen neprvih predlogov ter besed mesto, vas, trg, selo.

Primer: Murska Sobota, Loški Potok, Šmarje pri Jelšah, San Francisco, Novo mesto, Nemška vas itd.

Nenaselbinska imena so poimenovanja ulic, četrti, pokrajin, držav, celin, rek, morij, gora, dolin, planetov itd. (ibid., str. 74 ). $Z$ veliko začetnico zapišemo prvo besedo imena, ostale pišemo $z$ malo začetnico. Izjema so besede, ki označujejo lastno ime.

Primer: Rožna dolina, Slovenske gorice, Indijski ocean, Južna Amerika itd. 


\subsection{PREDLOGI}

Predlogi so krajše besede, ki opredeljujejo natančnejša razmerja znotraj stavka (Gomboc, 2009, str. 100). Pogosto pride do zamenjave določenih predlogov, ki imajo enako funkcijo, a za njih veljajo specifična slovnična pravila.

Tako pride do zamenjave predlogov $s$ in $z$. Predlog s uporabimo pred nezvenečimi nezvočniki (vsi soglasniki iz povedi: Ta suhi škafec pušča), predlog z pa pred samoglasniki, zvočniki in zvenečimi nezvočniki (vse ostale črke) (ibid., str. 51). Naslednji primer sta predloga $\mathrm{h}$ in k. Predlog h pišemo pred besedami na k ali g, predlog k pa pred vsemi drugimi glasovi (ibid., str. 51).

Primer: z nečakom, s kolesom, h kresu, k drevesu.

Predloge uporabimo tudi pri označevanju gibanja. Tako uporabimo predlog $v$, ko označujemo gibanje v notranjost nečesa, ter predlog iz, ko označimo gibanje navzven. Ko želimo prikazati gibanje vrh nečesa, uporabimo predlog na, za gibanje navzdol pa predloga s ali z (ibid., str. 100).

Primer: Potujem v Italijo. $\rightarrow$ Vračam se iz Italije. / Šel sem na morje. $\rightarrow$ Pošiljam ti pozdrave z morja.

\section{5 ŠTEVILA}

Tudi pri zapisu števil se držimo slovničnih pravil. Tako števnike do 100 in stotice z besedo pišemo skupaj, preostale števnike pa narazen. Skupaj pišemo tudi vrstilne, ločilne in množilne števnike. Če te števnike zapisujemo s števko, vmes zapišemo vezaj (Gomboc, 2009, str. 70). Pozorni smo tudi na zapis datuma. Za številkami, ki v datumu označujejo dan in mesec, je postavljena pika in sledi presledek. Ob številih, manjših od 10, ne pišemo dodatne ničle.

Primer:

- sedeminosemdeset, tristo dve

- stodvanajsti, stotisočer, petkraten, osemnajstletnica

- 18-letnica

- 16. 6. 2016 // 9. 8. 2017 // 29.11. 1958

\subsection{POSEBNI ZNAKI V BESEDILU}

Druga pisna znamenja ali nečrkovna znamenja se velikokrat pojavijo $v$ znanstvenih besedilih. To so na primer znaki za odstotke (\%) in promile (\%o) ter denarne enote $(€)$, ki se pišejo nestično, kar pomeni, da je pred znaki presledek (Dobrovoljc in Jakop, 2011, str. 55).

Primer:

V raziskavi smo odkrili, da ima $35 \%$ anketirancev večjo plačo od $1.500 €$ bruto.

$S$ hitrim pregledom sloga znanstvenega pisanja $v$ turizmu želimo spodbuditi jezikovno kulturo študentov in bodočih turističnih delavcev. Jezikovna kultura je opredeljena kot sledenje jezikovnim pravilom (ožji pomen) ter nega in razvoj knjižnega jezika ( $v$ širšem pomenu) (Kalin- 
Golob, 1996, str. 40). Stremimo k temu, da bo tudi jezik na področju turizma dobro razvit in negovan.

\section{Viri poglavja:}

Gomboc, M. (2009). Mala slovnica slovenskega jezika: priročnik za šolo in vsakdanjo rabo. Ljubljana: DZS.

Dobrovoljc, H. in Jakop, N. (2011). Sodobni pravopisni priročnik med normo in predpisom. Ljubljana: Založba ZRC.

Sternad, S., Boršič, D. in Tominc, P. (2013). Navodila za izdelavo pisnih del na Ekonomskoposlovni fakulteti. Maribor: Ekonomsko-poslovna fakulteta.

Toporišič, J. (2008). Stilnost in zvrstnost. Ljubljana: Založba ZRC, ZRC SAZU.

Kalin-Golob, M. (1996). Jezikovna kultura in jezikovni kotički. Ljubljana: Jutro. 


\title{
7. POGLAVJE
}

\section{NAVAJANJE LITERATURE IN VIROV}

\author{
Avtorica: Maja Rosi
}

DOI: https://doi.org/10.18690/978-961-286-076-9.7

Pri pisanju znanstvenih strokovnih del se velikokrat navezujemo na informacije in ideje drugih avtorjev, zato je treba strogo ločiti avtorjev tekst od tujega teksta, tujih spoznanj, misli, idej, podatkov, ilustracij in drugo. Pisec znanstvenega in strokovnega dela lahko prevzame definicije pojmov, znanstvena dejstva, ideje, podatke, informacije, ilustracije in drugo, vendar mora vedno na jasen in običajen način navesti, čigavo je in od kod je vse to prevzel. Navedba virov dodaja verodostojnost našemu delu in kredibilnost našim argumentom, prav tako pa bralcu omogoča najti dodatne informacije o izbrani tematiki.

Pri navajanju virov imamo na razpolago številne sloge pisanja, kot so APA (American Psychological Association), Chicago, Harvard, ACS (American Chemical Society), MLA (Modern Language Association) itd. Po navadi vsako področje zahteva svoj slog pisanja. Na primer slog APA se uporablja predvsem $v$ družboslovju, poslovnih in izobraževalnih vedah, MLA se uporablja v humanističnih vedah, AMS v matematiki in računalništvu, ACS v kemiji itd. Uporaba ustreznega sloga je odvisna tudi od navodil posameznih založnikov publikacij, v katerih bi želeli objaviti svoje delo. Tako na primer publikacije s področja političnih ved zahtevajo uporabo stila APA, kadar želijo sprotno navajanje virov (torej v besedilo), in stila Chicago, kadar želijo navedbo virov v sprotnih ali končnih opombah (Lipson, 2011, str. 4-6). Tem navodilom je treba slediti, če si prizadevamo za objavo našega prispevka v njihovih publikacijah.

Znotraj družboslovja torej najpogosteje uporabljamo slog navajanja virov APA (American Psychological Association), katerega standardi veljajo tudi za pisanje znanstvenih člankov, strokovnih člankov, seminarskih nalog, poročil, diplomskih in magistrskih del na Fakulteti za turizem Univerze v Mariboru. Pravila navajanja virov po standardu APA so povzeta po priročniku Publication manual of the American Psychological Association - 6th edition, 2010 (več na spletni strani: www.apa.org), in prilagojena za pisanje pisnih in zaključnih del na Fakulteti za turizem Univerze $v$ Mariboru.

\subsection{KDAJ JE TREBA NAVESTI VIR?}

Vir navedemo takrat, kadar delo nekega drugega avtorja (njegove ideje, teorije, raziskave) neposredno vpliva na naše delo. Delo drugih avtorjev nam omogoča pridobivanje osnovnih informacij, pomaga pri preverjanju zastavljenih hipotez in/ali raziskovalnih vprašanj, ponuja pomembne definicije in podatke. Navajanje virov drugih avtorjev pomeni, da smo njihovo delo osebno prebrali in da se ali strinjamo ali ne strinjamo z avtorjevimi idejami ter da priznavamo njihov trud, ki so ga vložili v pisno delo.

Število navedenih virov se razlikuje glede na vsebino in namen našega pisnega dela, $v$ splošnem pa velja, da navajanja virov ni nikoli preveč. Kadar povzemamo ideje, misli, podatke, slike, tabele, grafe in drugo, pa če le en stavek ali misel drugega avtorja, moramo to ustrezno 
navesti, saj v nasprotnem primeru govorimo o plagiatorstvu oziroma kraji intelektualne lastnine.

»Avtorji ne predstavljajo dela drugih avtorjev, kot da je to njihovo lastno delo! «(APA, 2010, str. 16). Da bi se izognili nevšečnostim, ki jih povzroča plagiatorstvo, je treba dosledno upoštevati pravila navajanja virov, ki jih podajamo v nadaljevanju.

O navajanju virov govorimo takrat, kadar:

1. dobesedno citiramo iz nekega vira (kopiramo/prepišemo iz vira črko za črko),

2. povzemamo ali preoblikujemo informacijo iz nekega vira s svojimi besedami.

\subsubsection{DOBESEDNO CITIRANJE IZ VIRA}

Če tuje besedilo navedemo dobesedno, je treba uporabiti narekovaje (" " ali » «), pri čemer mora biti besedilo povsem identično originalu. Če je v originalu uporabljena poševna pisava, jo moramo uporabiti tudi mi. Če pri prevzemanju besedila izpustimo nekaj besed ali stavkov, moramo to tudi označiti s tremi pikami. Dobesedno citiranje, ki mora biti uporabljeno v skladu z navodili, je v zaključnih delih torej dovoljeno in kaže tudi na avtorjevo »zrelost « sprejemanja tujih virov.

Kadar dobesedno citiramo, je treba v tekstu napisati avtorja, leto (in stran, s katere smo citirali, ali številko odstavka za neoštevilčena dela) in vir dodati na seznam virov ter literature.

\section{Primer:}

Pri interpretaciji tega pojma si pomagajmo z definicijo avtorjev Žigoni in Konečnik Ruzzier (2014, str. 78), ki pravita, da »gorskokolesarske destinacije predstavljajo podskupino avanturističnih destinacij oziroma destinacij, ki temeljijo na naravi, vendar pa so potrebe in zahteve njihove ciljne skupine specifične in se bistveno razlikujejo od potreb in zahtev ostalih obiskovalcev«, s čimer smo to tematiko še dodatno podkrepili.

Če se dobesedni citat pojavi na koncu stavka, pa to zapišemo kot:

Strinjam se, da »gorskokolesarske destinacije predstavljajo podskupino avanturističnih destinacij oziroma destinacij, ki temeljijo na naravi, vendar pa so potrebe in zahteve njihove ciljne skupine specifične in se bistveno razlikujejo od potreb in zahtev ostalih obiskovalcev« (Žigoni in Konečnik Ruzzier, 2014, str. 78).

\subsubsection{POVZEMANJE}

O povzemanju govorimo takrat, kadar smiselno povzamemo ali preoblikujemo neko informacijo, del stavka, misli drugega avtorja iz nekega vira s svojimi besedami, zato da jo na ta način lahko bolje integriramo v kontekst našega besedila.

\section{Primer:}

Eco (2003, str. 46) meni, da si v idealnem primeru tako nalogo kot tudi svetovalca izberemo proti koncu drugega letnika študija, saj smo takrat že seznanjeni z vsebino posameznih strokovnih predmetov. 
$\checkmark$ idealnem primeru si tako nalogo kot tudi svetovalca izberemo proti koncu drugega letnika študija, saj smo takrat že seznanjeni z vsebino posameznih strokovnih predmetov (Eco, 2003, str. 46).

Pri navajanju virov je treba ločiti:

1. VIRE $\vee$ BESEDILU (ki so $v$ besedilu in bralcu povedo, katere informacije so bile izposojene/povzete in čigave so te informacije),

2. SEZNAM VIROV (ki je na koncu besedila in pove bralcu, kateri viri so bili uporabljeni za pisanje besedila, ter zagotavlja popolne informacije o uporabljenih virih).

\subsection{NAVAJANJE VIROV V BESEDILU}

Vire $v$ besedilu navajamo takrat, kadar smo povzeli misli, izjave, podatke, slike, tabele, grafe drugih avtorjev. Vire navajamo sproti in jih sočasno po abecednem redu razvrščamo $v$ seznam virov, ki je na koncu našega besedila. Pri tem je pomembno, da je vsak vir, iz katerega smo citirali ali povzemali besedilo, tudi na seznamu virov. Velja seveda tudi obratno: da vsak vir, ki je $v$ seznamu virov, najdemo tudi $v$ besedilu.

$\checkmark$ nadaljevanju podajamo primere navajanja virov $v$ besedilu.

\section{En avtor}

Kadar navajamo po enem avtorju, bodimo pozorni na to, da na primernem mestu $v$ besedilu navedemo priimek avtorja, leto publikacije in stran (če je ta razvidna), pri čemer ne navajamo pripon, kot so dr., ga., g. in podobno:

Walker (2000, str. 20) je primerjal odzivne čase ...

V študiji o odzivnih časih ... (Walker, 2000, str. 20).

Kadar se priimek avtorja pojavi kot v prvem primeru, $v$ oklepaju navedemo samo leto in stran, kadar uporabimo povzemanje na način, ki je predstavljen v drugem primeru, potem v oklepaju na koncu povzetega dela besedila zapišemo priimek avtorja, leto in stran (ločeno $z$ vejico) ter za oklepajem naredimo piko.

$\checkmark$ primeru kombinacije prvega in drugega načina navajanja virov bodite pozorni na ustrezen zapis vira:

Walker (2000, str. 20) je primerjal odzivne čase ... Študija je razkrila tudi to, da so odzivni časi ... (Walker, 2000, str. 20).

ali

V študiji o odzivnih časih ... (Walker, 2000, str. 20). Walker (2000, str. 20) nadalje ugotavlja tudi to, da ...

\section{Dva avtorja}

Kadar ima delo dva avtorja, vselej navedemo oba avtorja v besedilu. Med oba priimka vstavimo veznik »in«:

Walker in Saleh (2000, str. 25)

ali (Walker in Saleh, 2000, str. 25) 


\section{Trije do vključno pet avtorjev}

Prvič navedemo vse avtorje, pred zadnjim dodamo veznik »in «, naslednjič pa po prvem avtorju uporabimo okrajšavo »et al.« ali »idr.«. Vsekakor pa se skozi besedilo uporablja enotna oznaka, oznak »et al.« ali »idr.« nikoli ne kombinirano v enem besedilu.

Prvo navajanje vira:

Wasserstein, Zappulla, Rosen, Gerstman in Rock (1994, str. 32) so ugotovili ... ali (Wasserstein, Zappulla, Rosen, Gerstman in Rock, 1994, str. 32)

Drugo navajanje vira:

Wasserstein et al. (1994, str. 32) so ugotovili ... ali (Wasserstein et al., 1994, str. 32).

IZJEMA: Če imamo več virov, po katerih citramo, z več avtorji, kjer so prvi avtorji in leto enaki in zato ne moremo razlikovati virov, moramo navesti vse avtorje, do vključno prvega, ki se razlikuje:

Ireys, Chernoff, DeVet et al. (2001, str. 51) in Ireys, Chernoff, Stein et al. (2001, str. 51)

\section{Šest ali več avtorjev}

Kadar je avtorjev šest ali več, vsakič, ko citiramo, navedemo (tudi ob prvem navajanju) le prvega avtorja in dodamo »et al.«ali »idr.«:

Kosslyn et al. (1998, str. 121) ali (Kosslyn et al., 1998, str. 121)

IZJEMA: Če imamo več virov, po katerih navajamo, z več avtorji, kjer so prvi avtorji in leto enaki, npr. Kosslyn, Koening, Barrett, Cave, Tang in Gabrieli (1996, str. 14) in Kosslyn, Koening, Gabrieli, Tang, Marsolek in Daly (1996, str. 21) in zato ne moremo razlikovati virov, moramo navesti vse avtorje do vključno prvega, ki se razlikuje:

Kosslyn, Koenig, Barret et al. (1996, str. 14) in Kosslyn, Koenig, Gabrieli et. al (1996, str. 21)

\section{Orqanizacija ali skupina kot avtor}

Ime organizacije, skupine, zveze, vladne agencije, študijske skupine itd. napišemo vedno, kadar se kot avtor pojavi $v$ besedilu. $V$ prvi navedbi vira po navadi uporabimo celoten izpis skupine, $v$ nadaljevanju pa uporabimo okrajšave. Okrajšave uporabimo smiselno in upoštevamo pravilo, da morajo podati zadostne informacije $v$ besedilu, da jih lahko bralec enostavno najde $v$ seznamu virov.

Prva navedba vira $v$ besedilu:

National Institute of Mental Health (NIMH, 2003)

Druga navedba vira $v$ besedilu:

NIMH (2003) 
Če je ime skupine kratko oziroma je njegovo krajšanje nerazumljivo, ga je treba vsakič, ko navajamo vir, $v$ celoti izpisati.

Prva navedba vira $v$ besedilu:

University of Pittsburgh (2005) ali (University of Pittsburgh, 2005)

Druga navedba vira $v$ besedilu:

University of Pittsburgh (2005) ali (University of Pittsburgh, 2005)

\section{Avtorja z enakim priimkom}

Če $v$ seznamu virov najdemo vire $z$ dvema ali več primarnih avtorjev $z$ enakim priimkom, potem $\mathrm{v}$ navajanju $\mathrm{v}$ besedilu vključimo začetnice imen prvega avtorja skozi celotno besedilo. Začetnice bralcu pomagajo razlikovati med avtorji z enakimi priimki v seznamu virov:

Viri v seznamu virov:

Light, I. (2006). Deflecting immigration: Networks, markets, and regulation in Los Angeles. Russell Sage Foundation.

Light, M. A. in Light, I. H. (2008). The geographic expansion of Mexican immigration in the United States and its implications for local law enforcement. In Law Enforcement Executive Forum Journal 8(1), 73-82.

Navedba vira $v$ besedilu:

Med drugim smo analizirali tudi študijo M. A. Light in Light (2008) ter I. Light (2006).

\section{Dela anonimnih avtorjev ali neidentificiranih avtorjev}

Kadar neko besedilo nima identificiranega avtorja, je treba $v$ besedilu citirati nekaj prvih besed vira iz seznama virov (najpogosteje je to naslov) in leto. Pri navedbi dodajte del naslova, poglavja ali naslova spletne strani v navednice (» «), medtem ko dajte naslov knjige, brošure ali poročila $v$ poševni tisk:

... so dosegli izjemen dosežek (»Study Finds«, 2007)

Knjiga College Bound Seniors (2008) govori o ...

IZJEMA: Kadar se avtor nekega besedila opredeljuje kot »anonimen«, potem citat v besedilu zapišete kot:

(Anonimen, 2013)

\section{Več avtorjev podaja isto misel}

Če je isto misel ali idejo podalo več avtorjev in želimo navesti vse, potem jih med seboj ločimo s podpičjem (;), po vrsti jih uredimo po abecednem vrstnem redu glede na priimek prvega avtorja:

(Kosslyn, 1996, str. 23; Koening, 1999, str. 43; Walker in Saleh, 2000, str. 5)

Če je isti avtor ali skupina avtorjev $v$ enem (istem) letu izdala več del, jim po vrsti dodamo črke $a, b, c$... in jih tako tudi navajamo. Enako velja tudi v seznamu virov na koncu besedila: Nekatere študije (Derryberry in Reed, 2005a, 2005b) so pokazale ... 


\section{Posredno navajanje}

Če je le mogoče, se takšni rabi izognemo in poskušamo pridobiti primarno referenco, torej originalni prispevek navedenega avtorja. Če res ne gre drugače, na primer kadar originalno delo ni več $v$ tisku ali nedostopno ali v nam nerazumljivem jeziku, potem $v$ besedilu posredno navedemo vir tako:

Tavčar (v Ule in Kline, 1996, str. 121) meni ali

Tavčar (povzeto po Ule in Kline, 1996, str. 121)

V angleškem jeziku bi to zapisali kot:

Tavčar (as cited in Ule and Kline, 1996)

\section{Navajanje točno določeneqa dela vira}

Če želimo natančno navesti točno določen del besedila nekega vira, je treba nakazati stran, poglavje, tabelo, graf, enačbo v delu besedila, ki ga navajamo. Pri tem je treba upoštevati, da kadar dobesedno citiramo, vedno uporabimo številko strani. Kadar uporabimo številko strani, uporabimo okrajšavo »str.«, kadar uporabimo poglavje, besedo izpišemo v celoti - »poglavje«:

(Centers for Disease Control and Prevention, 2005, str. 10)

(Shimamura, 1989, poglavje 3)

\section{Osebna komunikacija}

Osebna komunikacija so pisma, zapiski, elektronska pošta, osebni intervjuji, telefonski pogovor itd. Vire osebne komunikacije navajamo tako, da uporabimo začetnice in priimke avtorja, $s$ katerim smo komunicirali, in napišemo čim bolj natančen datum:

T. K. Lutes (osebna komunikacija, 18. 4. 2001) ali (T. K. Lutes, osebna komunikacija, april 2001)

Opomba: Osebno komunikacijo (intervjuji, telefonski pogovor) dobesedno zapišemo z vprašanji in odgovori ter priložimo kot prilogo.

\section{Nenatisnjen vir}

Vir, ki je še v tisku, navajamo tako kot ostala dela, le da namesto letnice napišemo »v tisku«, tako na primer citiramo:

Walker (v tisku) je ugotovil ...

Na enak način se delo v tisku citira tudi v seznamu virov na koncu članka, torej namesto letnice navajamo omenjeno besedno zvezo.

\section{Zaporedno sklicevanje na isti vir}

Kadar se $v$ besedilu sklicujete zaporedoma na isti vir in med tem niste navajali drugega vira, lahko po prvem navajanju naslednji isti vir označite tako: (ibid.), kadar gre za sklicevanje na del besedila na isti strani, ali tako: (ibid.; str. 30), kadar gre za sklicevanje na del istega besedila na drugi strani. 


\section{Vsi v besedilu navedeni viri (razen osebne komunikacije) morajo biti navedeni v seznamu virov in obratno - vse, kar najdemo v seznamu virov, mora biti tudi nekje med besedilom.}

\subsection{SEZNAM VIROV}

Seznam virov na koncu besedila podaja informacije o uporabljenih virih in informacije o pridobivanju virov. $V$ seznamu so po abecednem redu zvrščeni samo tisti viri, ki se uporabijo kot navedbe $v$ besedilu, brez virov osebne komunikacije.

\subsubsection{PRIPRAVA SEZNAMA VIROV}

Osnovni namen seznama virov je bralcu zagotoviti pridobivanje in uporabo virov, zato mora biti seznam popoln in pravilno oblikovan. Vsak vnos po navadi vsebuje naslednje elemente: avtorja, leto izdaje, naslov in podatke o izdaji - vse informacije, ki so potrebne za identifikacijo in knjižnično iskanje virov. Najboljši način za zagotavljanje natančnih in popolnih informacij je, da vsak vir posebej pregledamo in primerjamo $z$ originalno publikacijo. Poseben namen je treba posvetiti pravilnemu črkovanju imen in besed $v$ tujem jeziku, tudi naglasnim znamenjem ali drugim ločilom ter popolnosti naslovov revij, letnic, številki izdaje, številčenju strani in elektronskemu pridobivanju podatkov. Avtorji so odgovorni za vse informacije, ki jih navedejo v seznamu virov (APA, 2010, str. 180).

\section{Abecedno črkovanje virov}

Vire jo treba urediti $v$ abecednem redu po priimkih prvih avtorjev, ki jim sledi začetnica avtorjevega imena.

\section{Različna dela istega avtorja}

Kadar razvrščamo različna dela istega avtorja, je treba upoštevati naslednja pravila.

- Dela uredite kronološko od najstarejšega do najnovejšega:

- Upenieks, V. (2003)

- Upenieks, V. (2005)

- Če sta dve deli istega avtorja izdani v istem letu, pripišemo pri letnici izdaje prvega dela a (na primer: 2013a), pri letnici izdaje drugega dela pa b (na primer: 2013b):

- Baheti, J. R. (2001a). Control ...

- Baheti, J. R. (2001b). Roles of ...

- Če se isti avtor na seznamu enkrat pojavlja s samostojnim delom, drugič pa kot soavtor dela, najprej navedemo njegovo samostojno delo, nato pa delo, ki ga je pripravil v soavtorstvu (tudi če je bilo delo, kjer je več avtorjev, kronološko izdano prej):

- Alleyne, R. L. (2001)

- Alleyne, R. L. in Evans, A. J. (1999) 
- Če imamo posamezna dela različnih avtorjev, vendar z enakimi priimki, potem vire razvrstimo po abecednem redu začetnic imena:

- Mathur, A. L. in Wallston, J. (1999)

- Mathur, S. E. in Ahlers, R. J. (1998)

\section{Razvrščanje del skupin in del brez avtorjev}

Nekatera dela imajo kot avtorja navedemo skupino, agencijo, združenje, institucijo ali celo nimajo navedenega nobenega avtorja. Tudi takšna dela abecedno razvrstimo $v$ seznam virov med ostale avtorje glede na prvo besedo $v$ imenu skupine, agencije, institucije itd. Uporabimo uradna imena, izpisana v celoti (na primer: American Psychological Association in ne APA).

Kadar je avtor zapisan kot »anonimen«, na prvo mesto vnosa napišete Anonimen.

\section{Kadar vir nima avtorja, postavite naslov vira na mesto avtorja.}

Pravne dokumente obravnavajte na način kot vire brez avtorja, to pomeni, da jih abecedno razvrstite glede na prvo besedo ali okrajšavo vnosa vira.

Virov ne številčimo in pred njih ne dodajamo vrstičnih oznak. Vsak vir razvrstimo kot nov odstavek, in kadar se vir razteza čez več vrstic, drugo vrstico zamaknemo v desno, tako da naredimo viseči zamik odstavka:

Light, I. (2006). Deflecting immigration: Networks, markets, and regulation in Los Angeles. Russell Sage Foundation.

\section{Posebnosti tujih priimkov}

Pri avtorjih s priimki, kot so van der Borg, de Albuquerque in drugo, upoštevajte, da so predikati »van « in »de« sestavni del priimka. Avtorja s priimkom van der Borg boste zato na seznamu literature in virov uvrstili pod črko $V$; enako velja za avtorja s priimkom de Albuquerque - na seznamu literature in virov ga boste uvrstili pod črko D.

Namig: Za lažjo pripravo seznama virov ter pravilno oblikovanje si lahko pomagate $z$ internetnim iskalnikom Google učenjak (angl. Google scholar), kjer poiščete literaturo (akademsko literaturo), ki jo želite navesti, in s klikom na »navedi« pridobite seznam zapisa izbrane literature. Izberete zapis APA. Ko izpis kopirate v svoj dokument, pazite, da ohranite poševen tisk (obdržite oblikovanje). Vsako navedbo, pridobljeno s pomočjo Google učenjaka, pa velja vedno preveriti, saj se tudi tukaj dogaja, da navedbe niso podane $v$ skladu s pravili APA. Primera sta predstavljena na Sliki 2 in Sliki 3.

\footnotetext{
${ }^{4}$ Google učenjak služi za iskanje člankov, disertacij, knjig, poročil in druge akademske literature iz različnih virov založnikov, arhivov odprtega dostopa, spletnih mest akademskih institucij. Iskanje poteka tudi po citirani literaturi.
} 
Slika 2: Navajanje virov s pomočjo iskalnika Google učenjak 1

\section{Tourism destination brand identity: The case of Slovenia}

M Konecnik, F Go - Journal of Brand Management, 2008 - Springer

Abstract This paper explores the concept of tourism destination brand identity from the supply-side perspective, in contrast to those studies that have focused on the demanddriven, tourists' perceived tourism destination brand image. Both researchers and Navedeno v 219 virih Sorodni članki Vse različice: 7 Navedi) Shrani Več

Vir: Google, 2017

Slika 3: Navajanje virov s pomočjo iskalnika Google učenjak 2

Navedi
Kopirajte in prilepite vnaprej oblikovano navedbo ali uporabite eno od povezav za uvoz
podatkov v urejevalnik bibliografske zbirke.
MLA Konecnik, Maja, and Frank Go. "Tourism destination brand identity: The case of
Slovenia." Journal of Brand Management 15.3 (2008): 177-189.
Konecnik, M., \& Go, F. (2008). Tourism destination brand identity. The case of
Slovenia. Journal of Brand Management, 15(3), 177-189.
KONECNIK, Maja; GO, Frank. Tourism destination brand identity: The case of
Slovenia. Journal of Brand Management, 2008, 15.3: 177-189.
BibTeX EndNote RefMan RefWorks

Vir: Google, 2017

Poleg tega pripomočka obstaja še vrsta drugih programov za pomoč pri navajanju virov in oblikovanju seznama literature, kot so Mendeley, EndNote, UMNIK itd.

\subsubsection{PRAVILA NAVAJANJA VIROV V SEZNAMU LITERATURE}

\section{En avtor do vključno sedem avtorjev}

Kadar ima vir enega do vključno sedem avtorjev, moramo navesti vse avtorje (priimke in velike začetnice imena) in pred zadnjim dodati veznik »in«:

Priimek, I., Priimek, I. in Priimek, I. (leto). Naslov. Kraj: Založba.

Domen, B., Pucko, D. in Sutherland, R. (1992). Economics and business organization. Ljubljana: Faculty of Economics.

\section{Osem avtorjev ali več}

Kadar ima vir osem ali več avtorjev, navedemo prvih šest avtorjev, dodamo tri pike in zadnjega avtorja.

Gilbert, D. G., McClernon, F. J., Rabinovich, N. E., Sugai, C., Plath, L. C., Asgaard, G., ... Botros, N. (2004). Effects of quitting smoking on EEG activation and attention last for more than 31 days and are more severe with stress, dependence, DRD2 A1 allele, and depressive traits. Nicotine \& Tobacco Research, 6(2), 249-267. 
V besedilu navedemo vir kot: (Gilbert et al., 2004, str. 250).

\section{Dva avtorja $z$ istim priimkom in enakimi začetnicami imena}

Kadar imamo dva avtorja $z$ istim priimkom in enakimi začetnicami imena, potem moramo avtorjevo polno ime napisati $v$ oglatih oklepajih za začetnico imena:

Janet, P. [Paul] (1928). L'evolution de la memoire et de la notion du temps (Vol. 1). Paris: A. Chahine.

Janet, P. [Piere] (1906). On the pathogenesis of some impulsions. The Journal of Abnormal Psychology, 1(1), 1.

$\checkmark$ besedilu navedemo vir kot:

(Paul Janet, 1928, str. 10)

(Paul Piere, 1906, str. 12)

\section{Skupina avtorjev}

Nekatera dela imajo kot avtorja navedeno skupino, agencijo, združenje, institucijo ali celo nimajo navedenega nobenega avtorja. Pri skupini avtorjev uporabimo uradna imena, izpisana $\checkmark$ celoti (na primer American Psychological Association in ne APA).

American Psychological Association. (1994). Publication manual of the American psychological association. Washington: American Psychological Association.

$\checkmark$ besedilu navedemo vir kot:

- prvo navajanje vira: (American Psychological Association [APA], 1994, str. 113)

- vsako naslednje navajanje: (APA, 1994, str. 190)

\section{Viri z uredniki}

Kadar ima vir urednika oziroma urednike, se ti pišejo za naslovom dela, tako da pred urednika dodamo črko V. Urednike zapišemo tako, da najprej napišemo začetnico imena, priimek in dodamo(ur.).

Plath, S. (2000). The unabridged journals. V KV. Kukil (ur.). New York, NY: Anchor.

Kadar je znan samo urednik (in ni avtorjev):

Gibbs, J. T. (ur.). (1991). Children of color: psychological interventions with minority youth. San Francisco: Jossey-Bass.

\section{Vir $v$ tisku}

Kadar navajamo vir, ki je v tisku in še ni objavljen, na mesto letnice napišemo »v tisku«:

Briscoe, R. ( $v$ tisku). Egocentric spatial representation in action and preception. 


\section{Leto objave vira ne obstaja}

Kadar leto objave vira ne obstaja, $v$ oklepaju namesto letnice napišemo b. d. (kar pomeni: brez datuma). $v$ besedilu napišemo kratico b. $d$.

\section{Uporaba poševnega tiska}

Pri monografijah (knjige, diplomsko delo, magistrsko delo, doktorsko delo, raziskovalna poročila, prispevki iz zbornikov konferenc in drugo) se v poševnem tisku pišejo naslovi del.

Pri člankih (revije, časopisi, časniki in drugo) pa se $v$ poševnem tisku piše ime revije in letnik/volumen.

\section{Datum dostopanja do spletnih virov}

Ob vseh virih, ki smo jih pridobili na spletu, moramo poleg povezave na spletno stran navesti tudi datum našega dostopa, ki ga dodamo za URL-naslovom gradiva/vira. Način navedbe je prikazan na primerih v nadaljevanju.

\subsubsection{PRIMERI NAVEDB VIROV V SEZNAMU VIROV GLEDE NA VRSTO VIRA}

V nadaljevanju podajamo primere navedb virov $v$ seznamu virov gleda na posamezno vrsto vira.

\section{ČLANKI V REVIJAH, ČASOPISIH, ČASNIKIH}

Priimek, Začetnice imena. (leto). Naslov. Ime revije, volumen(številka), prva stran člankazadnja stran članka.

Prašnikar, J., Cirman, A. in Domadenik, P. (2001). Investment activities of Slovenian companies in the countries of former Yugoslavia. Economic and business review, 3(2), 137-154.

\section{Članki v revijah, pridobljeni na spletu}

Prašnikar, J., Cirman, A. in Domadenik, P. (2001). Investment activities of Slovenian companies in the countries of former Yugoslavia. Economic and business review, 3(2), 137-154. Pridobljeno iz http://www.xxxyyy, datum dostopanja.

\section{Članki iz časopisov in časnikov}

Weiss, M., Šimac, J. in Elikan, J. (17. 5. 2012). Prihodnost za gradbeništvo zlasti na tujih trgih. Finance, št. 61, str. 6-7.

\section{Članki iz časopisov in časnikov s spleta}

Weiss, M., Šimac, J. in Elikan, J. (17. 5. 2012). Prihodnost za gradbeništvo zlasti na tujih trgih. Finance. Pridobljeno iz http://www.finance.si/347316/Prihodnost-zagradbeni\%C5\%A1tvo-zlasti-na-tujih-trgih, 4. 5. 2017. 


\section{Članki iz časopisov in časnikov - brez avtorja}

Six Sites Meet for Comprehensive Anti-Gang initiative conference. (november/december 2006).
OJJDP
News
@
a Glance.
Pridobljeno
iz

https://www.ncjrs.gov/html/ojjdp/news_at_glance/216684/topstory.html, 4. 5. 2017.

\section{KNJIGE, POGLAVJA V KNJIGAH}

Pri navedbah knjig uporabimo naslednji zapis:

Priimek, Začetnice imena. (leto). Naslov. Kraj: Založnik.

Priimek, Začetnice imena. (leto). Naslov. Pridobljeno iz http://www.xxyy..., datum dostopanja.

Priimek urednika, Začetnice imena. (ur.) (leto). Nas/ov. Kraj: Založnik.

\section{Knjiga v tiskani izdaji}

Potočnik Topler, J. (2017). On tourism discourse and other issues in tourism: scientific monograph. Harlow [etc.]: Pearson.

\section{Elektronska verzija objavljene knjige}

Speed, H. (2004). The practice and science of drawing. Pridobljeno iz http://www.gutenberg.org/etext/14264, 5. 5. 2017.

\section{Knjiga, katere avtor ni znan}

Publication Manual of the American Psychological Association (5th Ed.). (2003). Washington, DC: American Psychological Association.

\section{Poglavje v knjigi}

Priimek, Začetnice imena. (leto). Naslov poglavja. V Začetnice imena urednika. Priimek urednika (ur.), Naslov knjige (str. prva stran poglavja-zadnja stran poglavja). Kraj: Založnik.

Zgaga, P. (2001). Znanje je moč, je (lahko) tudi stvar demokracije? V K. Majerhold (ur.), Ali se univerza vrti v krogu svoje moči? (str. 9-26). Ljubljana: Študentska organizacija Univerze $v$ Ljubljani.

\section{RAZISKOVALNO POROČILO}

\section{Raziskovalno poročilo v tiskani verziji}

Priimek, Začetnice imena. (Leto). Naslov (Raziskovalno poročilo). Kraj: Založnik.

Devjak, T., Cencič, M. in Polak, A. (2005). Model izpopolnjevanja oziroma stalnega strokovnega izpopolnjevanja kot oblike vseživljenjskega učenja strokovnih delavcev $v$ vzgoji in izobraževanju (Raziskovalno poročilo). Ljubljana: Pedagoška fakulteta. 


\section{Raziskovalno poročilo v elektronski verziji}

Devjak, T., Cencič, M. in Polak, A. (2005). Model izpopolnjevanja oziroma stalnega strokovnega izpopolnjevanja kot oblike vseživljenjskega učenja strokovnih delavcev $v$ vzgoji in izobraževanju (Raziskovalno poročilo). Pridobljeno iz http://www2.arnes.si/ icerar/Devjak,Polak_Nadaljnje\%20izobrazevanje.pdf., 5. 5. 2017.

\section{PRISPEVKI S KONFERENC, KONGRESOV IN SIMPOZIJEV}

\section{Prispevek v zborniku, brez urednika}

Priimek, Začetnice imena. (mesec, leto). Naslov prispevka. V Naslov zbornika. (str. prva stran prispevka-zadnja stran prispevka). Kraj: Založnik.

Katz, I., Gabayan, K. in Aghajan, H. (avgust, 2007). A multi-touch surface using multiple cameras. V International Conference on Advanced Concepts for Intelligent Vision Systems (str. 97-108). Berlin: Springer Berlin Heidelberg.

\section{Prispevek v zborniku, z urednikom ali več uredniki}

Armstrong, D. B., Fogarty, G. J. in Dingsdag, D. (2007). Scales measuring characteristics of small business information systems. V W-G. Tan (ur.), Proceedings of Research, Relevance and Rigour: Coming of age: 18th Australasian Conference on Information Systems (str. 163-171). Toowoomba, Australia: University of Southern Queensland.

\section{Prispevki konferenc, simpozijev, kongresov v elektronski verziji}

Taylor, J. A. (november 2006). Assessment: a tool for development and engagement in the first year of university study. Prispevek predstavljen na konferenci Engaging Students: 9th Pacific Rim in Higher Education (FYHE) Conference, Griffith, Australia. Pridobljeno iz http://www.fyhe.com.au/past_papers/2006/Papers/Taylor.pdf, 6. 5. 2017.

\section{DIPLOMSKA, MAGISTRSKA ALI DOKTORSKA DELA}

\section{Diplomsko, magistrsko ali doktorsko delo v tiskani verziji}

Priimek, Začetnice imena. (leto). Naslov. (Diplomsko delo). Ime institucije, Kraj.

Priimek, Začetnice imena. (leto). Naslov. (Magistrska naloga). Ime institucije, Kraj.

Priimek, Začetnice imena. (leto). Naslov. (Doktorska disertacija). Ime institucije, Kraj.

\section{Diplomsko, magistrsko ali doktorsko delo v elektronski verziji}

Priimek, Začetnice imena. (leto). Naslov. (Diplomsko delo, Ime institucije). Pridobljeno iz http://www.xxyy, datum dostopanja.

Priimek, Začetnice imena. (leto). Nas/ov. (Magistrska naloga, Ime institucije). Pridobljeno iz http://www.xxyy, datum dostopanja.

Priimek, Začetnice imena. (leto). Nas/ov. (Doktorska disertacija, Ime institucije). Pridobljeno iz http://www.xxyy, datum dostopanja. 


\section{Neobjavljeno delo ali neformalno objavljeno delo}

Neobjavljeno delo je delo, ki je še v fazi nastajanja, vendar je bilo sprejeto za objavo, ali delo, ki je že končano, vendar še ni objavljeno.

Priimek, Začetnice imena. (Leto). Naslov. Neobjavljeno delo.

Priimek, Začetnice imena. (Leto). Naslov. Delo posredovano v objavo.

Priimek, Začetnice imena. (Leto). Naslov. Delo je v pripravi.

Primer:

Kremžar, B. (1985). Motorika predšolskega otroka: študijsko gradivo. Neobjavljeno delo.

\section{PRISPEVKI S SPLETNIH STRANI}

Vire s spletnih strani navajamo na enak način kot knjige, članke, dodamo spletni naslov, od koder smo vir pridobili, za njim pa še datum dostopanja do spletne strani.

\section{Poljubne spletne strani}

Avtor. (datum zadnje posodobitev ali datum avtorske pravice; če datuma ni, napišete b. d.). Ime dokumenta. Pridobljeno iz URL-dokumenta, datum dostopanja do spletne strani.

Beard, M. (2006). The fall of the Roman Republic. Pridobljeno iz http://www.bbc.co.uk/history/ancient/romans/fallofromanrepublic_article_01.shtml, 4. 5. 2017.

\section{Spletne strani univerz, fakultet}

Avtor. (datum zadnje posodobitev ali datum avtorske pravice; če datuma ni, napišete b. d.). Ime dokumenta. Pridobljeno iz Ime spletne strani univerze: URL-dokumenta, datum dostopa.

Johnson, K. A. in Becker, J. A. (2007). The whole brain atlas. Pridobljeno iz Harvard University Medical School website: http://www.med.harvard.edu/AANLIB/, 4. 5. 2017.

\section{Spletne strani brez datuma}

Avtor. (b. d.). Ime dokumenta. Pridobljeno iz URL-dokumenta, datum dostopa.

Royal Institute of British Architects. (b. d.). Shaping the future: Careers in architecture. Pridobljeno iz http://ww.careersinarchitecture.net/, 5. 5. 2017.

\section{$\underline{B l o g i}$}

Hagon, P. (27. 9. 2009). Immediate sharing [Web log post]. Pridobljeno iz http://www.paulhagon.com/ blog/2009/09/27/immediate-sharing/, 5. 5. 2017.

\section{Spletna stran podjetja ali organizacije}

Terme Čatež. (b. d.). Pridobljeno iz http://www.terme-catez.si/, 5. 5. 2017. 


\section{Prispevki s spletnih strani brez avtorja}

»Six sites meet for comprehensive anti-gang initiative conference«. (november/december, 2006). OJJDP News @a Glance. Pridobljeno iz

http://www.ncjrs.gov/html/ojjdp/news_at_glance/216684/topstory.html, 5. 5. 2017.

Opomba: Kadar prispevki s spleta nimajo avtorja, potem v seznamu literature in virov na mesto avtorja postavimo naslov prispevka in ga vstavimo med narekovaje. Med besedilom to zapišemo tako, da uporabimo skrajšan naslov (primer zgornje navedbe: (»Six Sites Meet", 2006)); kadar je naslov kratek, ga izpišemo v celoti.

\section{$\underline{D R U G I V I R I}$}

\section{Interno gradivo podjetja, organizacije}

Merkur, d. d. (2008). Sistemizacija delovnih mest v podjetju Merkur, d. d.. Interno gradivo. Kranj: Merkur, d. d.

\section{Televizijska ali radijska oddaja}

Šterbucl, S. (urednik). (2008). Dnevnik [televizijska oddaja]. Ljubljana: RTV Slovenija.

\section{Videogradivo}

Cage, K. (Writer). (2008). Time management for university students [DVD]. New Zealand: Massey University.

\section{Brošure}

Priimek, Začetnice imena. (leto). Naslov brošure. [Brošura]. Kraj: Založnik.

\section{Zakonodajni viri}

Zakon o varnosti cestnega prometa. Uradni list RS, št. 56/2008-UPB5, 57/2008-ZLDUVCP, 73/2008 Odl.US: U-I-295/05-38, 58/2009, 36/2010, 106/2010-ZMV, 109/2010-ZCes-1, 109/2010-ZPrCP, 109/2010-ZVoz, 7/2011 Odl.US: U-I-144/09-13, 39/2011-ZJZ-E, 47/2011 Odl.US: U-I-119/10-6.

\section{Viri poglavja:}

American Psychological Association. (2010). APA manual (publication manual of the American Psychological Association). Washington, DC: American Psychological Association.

Google učenjak. (2017). Iskalni kriterij: Tourism destination brand tha case of Slovenia. Pridobljeno https://scholar.google.si/scholar?q=tourism+destination+brand+tha+cese+of+slove nia\&btnG=\&hl=sl\&as_sdt=0\%2C5, 18. 5. 2017.

Lipson, C. (2011). Cite right: a quick guide to citation styles- MLA, APA, Chicago, the sciences, professions, and more. Chicago: University of Chicago Press. 



\title{
8. POgLAVJe
}

\section{OBLIKOVANJE BESEDILA}

\author{
Avtor: Nejc Pozvek
}

DOI: https://doi.org/10.18690/978-961-286-076-9.8

V poglavju o oblikovanju besedila bomo govorili o dveh vidikih. $\mathrm{V}$ začetku bomo predstavili členjenje besedila na enote (pogosto sta $v$ rabi tudi izraza strukturiranje besedila ali razrez besedila), ki je pravzaprav ena od najbolj začetnih, elementarnih faz priprave vsakega besedila in logično sledi raziskovalnemu procesu (ta je predstavljen $\vee 3$. poglavju). $\mathrm{V}$ drugem delu poglavja bomo obravnavali tehnično urejanje, pri katerem gre $v$ večji meri za spretnosti $z$ različnimi orodji za oblikovanje besedila oziroma njihovo obvladovanje - v našem primeru bo oblikovanje predstavljeno na primeru uporabe programa MS Office Word, ki je najpogosteje $v$ rabi. Tehnično podkovanost je možno pridobiti z lastnim raziskovanjem, na tečajih ali pa s pomočjo priročnikov na spletu in $v$ knjižnicah. Končni cilj tehničnega oblikovanja besedila je enoten videz, ki je z nekaterimi podrobnimi navodili tudi natančno predpisan.

\subsection{Strukturiranje besedila}

Pri postavitvi osnovne strukture (zgradbe) besedila se soočamo s členjenjem vsebine na posamezna poglavja, podpoglavja ipd. Proces strukturiranja se začne že pri začetnem snovanju naloge - še preden se ideja prelije na papir. Pri zaključnih delih je priprava dispozicije tisti del procesa nastajanja, kjer opredelimo/zastavimo strukturo besedila. Tudi pri vseh ostalih delih oziroma nalogah je smiselno strukturo opredeliti pred začetkom pisanja (ob snovanju oziroma razvijanju ideje), saj nam to lahko bistveno olajša nadaljnje delo. Pri seminarskih nalogah je struktura največkrat že vnaprej definirana na podlagi vsebine, ki jo morate predstaviti v nalogi.

Strokovna in znanstvena besedila (tako kot književna in ostala) sledijo klasični zasnovi - njihova zgradba je tridelna: ima uvod, jedro ter zaključek. Skoznje se predstavi, analizira in razreši nek (raziskovalni) problem. Vsakega od treh temeljnih vsebinskih delov poljubno členimo na poglavja in podpoglavja, ki nas po logični poti pripeljejo od začetne do končne točke besedila.

V UVODU je treba poskrbeti za:

- definiranje in opis problema (definicijo poskušamo zapisati jasno in koncizno, najbolje v enem stavku, za opis problema pa si navadno vzamemo malce več prostora);

- namen in cilje raziskave;

- hipoteze ali raziskovalna vprašanja;

- predpostavke in omejitve raziskave ter

- metode raziskovanja.

V uvodu je zelo priporočljivo navesti tudi osebne motive avtorja pri izboru neke teme, kjer pojasnimo, zakaj smo se za določeno temo odločili, kako smo do nje prišli, kako smo raziskovalno misel razvijali ipd. 
V JEDRU, ki predstavlja osrednji del besedila, podrobneje opišemo/predstavimo izbrano temo. Naslanjamo se na (relevantno!) domačo in tujo literaturo, s pomočjo katere razvijamo in pojasnjujemo izbrano tematiko. Jedro vsebinsko navadno razdelimo na:

- teoretični del (naslovimo ga skladno z vsebino naloge in smiselno razčlenimo na poglavja; med bistvene elemente tega dela sodijo dosedanja spoznanja o tej temi, torej prikaz že obstoječe literature);

- empirični del (obravnavamo metodologijo, kritično analiziramo, potrdimo ali ovržemo zastavljene hipoteze oziroma odgovorimo na raziskovalna vprašanja) in

- rezultate raziskave (predlagamo rešitve problema).

V ZAKLJUČKU besedila ne smemo pozabiti na:

- sklepne misli,

- povzetek ugotovitev raziskave,

- analizo doseženih ciljev ( $v$ primerjavi z zastavljenimi cilji),

- analizo in oceno dela z vidika namena (je bil namen dosežen ali ne) in

- opredelitev predlogov za nadaljnje raziskave.

\subsection{Tehnično urejanje besedila}

Kot že uvodoma predstavljeno, zahteva tehnično urejanje določeno spretnost oziroma znanje, ki je vezano predvsem na poznavanje programov za oblikovanje. Največjo prepoznavnost med njimi je nedvomno dosegel urejevalnik besedil Word iz zbirke Microsoft Office, na podlagi katerega so podani tudi primeri v nadaljevanju. Cilj tehničnega urejanja je estetski in predvsem ( $v$ našem primeru) enoten videz vseh del. Fakulteta za turizem z navodili in napotki, ki so predstavljeni $v$ nadaljevanju, postavlja svoje lastne standarde. Ti $v$ večji meri sledijo splošno sprejetim, uniformiranim pravilom, specifični detajli so redki. Pri zasnovi navodil smo se $\mathbf{v}$ določeni meri naslonili na že uveljavljena pravila drugih fakultet Univerze v Mariboru 5 .

Kot ključen pripomoček za pomoč pri tehničnem urejanju besedila naj študentom služita Predloga za pripravo zaključnih del na Fakulteti za turizem Univerze v Mariboru ${ }^{6}$ in Predloga za pripravo seminarskih nalog na Fakulteti za turizem Univerze v Mariboru, ki sta bili urejeni in posodobljeni ob nastajanju teh navodil. $\mathrm{V}$ njih je mogoče na praktičnih primerih videti in preveriti napisana navodila, kar omogoča bistveno lažjo predstavo, predvsem pa njuna uporaba zagotavlja pravilno oblikovanje, enoten izgled del in manj zapletov pri tehničnem pregledu nalog.

\footnotetext{
$5 \mathrm{~V}$ prvi vrsti nam je bil pri snovanju naših navodil o tehničnem oblikovanju oziroma urejanju besedil $v$ pomoč dokument Navodila za izdelavo pisnih del na Ekonomsko-poslovni fakulteti Univerze v Mariboru (avtorice Simona Sternad, Darja Boršić in Polona Tominc), ki so izšla v septembru 2013. V njih lahko študentje najdejo tudi številne koristne namige, ki olajšajo delo $v$ Wordu, zato jim jih lahko priporočimo $v$ rabo. Navodila so dostopna tudi na spletu.

6 Predloga za pripravo zaključnih dela na Fakulteti za turizem Univerze v Mariboru je na voljo na spletni strani fakultete. Do nje lahko dostopamo neposredno prek pripete povezave. Poleg omenjene predloge $v$ istem zavihku spletne strani najdete tudi Predlogo za pripravo seminarskih nalog na Fakulteti za turizem Univerze v Mariboru ter vse ostale informacije o pripravi (zaključnih) del.
} 


\subsubsection{Splošna pravila za oblikovanje/urejanje besedil}

Med splošnimi pravili bomo obravnavali osnovna navodila, ki zajemajo pripravo strani in robov, pisavo in odstavke, oblikovanje grafičnih elementov (slik in tabel) v besedilu, oblikovanje enačb, številčenje strani ter še nekatere druge podrobnosti.

\section{- Priprava strani in robov}

Povsem na začetku oblikovanja besedila je treba pripraviti stran (največkrat so te nastavitve sicer že programske), ob čemer moramo upoštevati velikost papirja (A4) in ustrezne robove, ki merijo na vsaki strani $2,5 \mathrm{~cm}$. Če bomo pisno delo vezali s trdo vezavo, je treba med nastavitvami robov nastaviti rob za vezavo na $1 \mathrm{~cm}$. $V$ tem primeru je treba biti pozoren tudi na tisk: če bo ta obojestranski, je treba med nastavitvami izbrati zrcalne robove.

Pisna dela naj bodo, tudi vsled okoljske zavesti, tiskana na obe strani. Izjema velja za začetne strani zaključnih del (do uvodnega (prvega) poglavja), ki jih natisnite enostransko. Pri izdelavi pisnih del, ki niso zaključna, velja preveriti morebitna dodatna navodila posameznih mentorjev, izvajalcev ali asistentov: večkrat zadošča že oddaja elektronske verzije izdelka, sicer pa jih natisnemo obojestransko.

Listi so usmerjeni pokončno. Izjemoma ( $v$ izrednih primerih velikih tabel ali grafičnih prikazov) lahko list obrnemo ležeče. To storimo tako, da ležečo stran »izoliramo《 z vstavljanjem preloma odseka (na novo stran).

\section{- Pisava in odstavki}

Skozi celotno pisno delo uporabljamo eno vrsto pisave, izbiramo pa lahko med Arial, Times New Roman, Tahoma in Calibri. Barva pisave mora biti vseskozi črna.

Osnovno besedilo pišemo z velikostjo 12 pik, poravnamo ga obojestransko. Krepek ali poševen tisk uporabimo zgolj izjemoma ob pomembnih poudarkih; podčrtovanja se izogibamo. ( $V$ pričujočih navodilih so zaradi narave/tipa dela krepek oziroma poševen tisk ter podčrtaj dodani kot elementi oblikovanja. Nasploh se v pisnih delih ne uporabljajo na ta način.)

Že pred začetkom pisanja si je smiselno za telo našega besedila nastaviti slog (o nastavitvi slogov je nekaj napotkov podanih še v nadaljevanju besedila), ki ga bomo uporabljali vseskozi. V zavihku Odstavek nastavimo razmik pred vrstico na 0 pik, za vrstico pa 12 pik (kar je v bistvu 1 vrstica). Naši odstavki bodo tako samodejno razmaknjeni za višino ene vrstice (12 pik). Prvih besed v odstavku ne zamikamo. Razmik med vrsticami naj bo enojen.

\section{- Naslovi poglavij}

Poglavja so v nalogi hierarhično strukturirana. Poglavje lahko vsebuje več podpoglavij, vendar v vsakem primeru najmanj dve. Poglavja so tvorjena iz več odstavkov. Če so zelo dolga, jih poskušamo smiselno razdeliti na manjše enote. Naslovov poglavij različnih ravni ne smemo nizati neposredno enega za drugim, temveč moramo vmes vedno dodati nekaj besedila.

Naslove poglavij 1. reda oziroma 1. ravni pišemo z velikostjo 16 pik, krepkim tiskom, z velikimi črkami in levo poravnavo. Glavni naslovi se vedno začnejo na novi strani - razmik pred naslovom zato nastavimo na 0 pik, za naslovom pa dve prazni vrstici (24 pik). 
Podnaslove 2. ravni pišemo v velikosti 14 pik, krepko, z malimi tiskanimi črkami (razen obveznih velikih začetnic), poravnamo jih levo. Razmik pred podnaslovom (2. raven) je 18 pik, za podnaslovom 12 pik. (V strukturiranju, kot že zgoraj zapisano, se moramo izogibati primeru, da bi glavnemu naslovu neposredno sledil podnaslov - enako velja tudi za nižje ravni. $\mathrm{V}$ nasprotnem primeru se podrejo tudi merila o razmikih pri oblikovanju naslovov.)

Podnaslove 3. ravni pišemo z velikostjo 12 pik, krepko in z malimi tiskanimi črkami (upoštevajoč veliko začetnico). Razmik pred in za podnaslovom (3. raven) je 12 pik.

Vse ravni naslovov številčimo z arabskimi številkami. Če imamo več ravni poglavij, številki ločimo s piko (brez presledka), za zadnjo številko pa pike ni - zapišemo kar besedilo naslova. Številčenje poglavij je enostavno s pomočjo uporabe slogov, ki nam omogočijo tudi preprosto vstavljanje kazala vsebine. Če smo uporabljali prednastavljene sloge (ki jih lahko po svoji meri tudi spremenimo), je za številčenje najenostavneje izbrati ustrezni večravenski seznam, ki je v programu Word že pripravljen.

\section{- Oblikovanje grafičnih elementov}

Slike (grafi, grafikoni, fotografije itd.) in tabele so namenjene preglednejšemu in nazornejšemu prikazu podatkov $v$ našem delu. Vsebinsko jih smiselno umestimo $v$ besedilo; poskušamo jih omeniti že pred prikazom, zahtevajo pa tudi sklicevanje (element sklica mora biti točno določen, npr. Slika 1 prikazuje ...) in pojasnilo. Napis grafičnega elementa je sestavljen iz oznake elementa (Slika oz. Tabela), zaporedne številke (z dvopičjem; oštevilčevanje poteka neprekinjeno skozi celotno pisno delo) in naslova vstavljene slike oziroma tabele (z veliko začetnico).

Vse napise nad grafičnimi elementi je zavoljo kasnejšega lažjega urejanja kazal smiselno urejati v zavihku Sklici, kjer med napisi vstavimo ustreznega (izberemo Slika ali Tabela). Napisi imajo velikost 12 pik in so (kakor tudi grafični elementi) sredinsko poravnani. Razmik pred napisom je 0 pik, napis in grafični element pa loči 6 pik. Pod grafičnim elementom dodamo vir (včasih tudi opombe) $v$ velikosti 10 pik, ležeče pisave in sredinsko poravnano. Od grafičnega elementa ga ločimo z razmikom 6 pik, za virom (opombo) pa je 12 pik razmika. $V$ kolikor imamo pod grafičnim elementom tako opombo kot vir, ju ločimo s 6 pikami razmika.

Če je grafični element naše samostojno delo (izjema so fotografije, kjer navedemo avtorstvo), navedbe vira ne potrebuje. Zapis vira je odvisen od načina povzemanja oziroma obdelave podatkov. Če je grafični element enak tistemu v izvornem viru, zapišemo » Vir: navedba vira, letnica, stran«. V kolikor smo uporabili podatke za izdelavo grafičnega elementa, je treba zapisati »Vir podatkov: navedba vira, letnica«. Če pa smo grafični element priredili, zapišemo »Prirejeno po: navedba vira, letnica, stran«.

\section{- Posebnosti oblikovanja tabel}

Tabele morajo imeti znotraj dokumenta enoten izgled. Načeloma se razprostirajo od levega do desnega roba, razen $v$ primeru, ko zaradi skromnosti vsebine to ni smiselno. $V$ tem primeru jih poravnamo na sredino. Tabele vedno vsebujejo glavo (1. vrstica) in večinoma tudi čelo (1. stolpec), v katerih je primerno poudariti besedilo (krepko) in ju obarvati (npr. desetodstotno sivo senčenje). Velikost pisave $v$ tabeli je 12 pik (izjemoma ob veliki količini podatkov manjša, npr. 11 pik), razmik med vrsticami je enojen, pred in za odstavkom razmika ni. Podatke 
poravnavamo smiselno (in enotno) glede na vsebino. Zunanji rob tabele je dvojen, notranji robovi so enojni.

- Urejanje enačb

Enačbe vedno zapisujemo v poševnem tisku z velikostjo 12 pik, poravnamo jih sredinsko. Vsako enačbo ( $v$ isti vrstici $z$ enačbo) ob desnem robu oštevilčimo $z$ arabsko številko $v$ oklepaju. Za lažje oblikovanje enačbe na opisan način si pomagamo z vstavljanjem tabele (ena vrstica, dva stolpca), ki ima nevidne robove. Pred in za enačbo pustimo prazno vrstico (12 pik).

\section{- Sprotne opombe}

S sprotnimi opombami (opombami pod črto) bodisi podrobneje pojasnjujemo svoje zapise ali usmerimo bralca na druge vire. Izjemoma s sprotno opombo navedemo vir (npr. Povzeto po: Priimek avtorja, letnica), po katerem smo povzeli celotno poglavje, kar pa za zaključna dela ni primerno (ni dovoljeno). Sprotne opombe pišemo v obliki stavkov (končamo s piko), z velikostjo 10 pik, pred in za odstavkom je razmik 0 pik, poravnamo jih obojestransko. Vstavimo jih $\mathrm{s}$ pomočjo zavihka Sklici.

\section{- Številčenje strani}

Strani številčimo na dnu - z arabskimi številkami, ki jih poravnamo na sredino. Prva oštevilčena stran je poglavje Uvod, zadnja pa zadnja stran poglavja Literatura in viri (oštevilčevanje prilog je opisano v nadaljevanju). Naslovnice (in ostalih strani pred uvodom) ne številčimo. Za zaključna dela velja, da lahko, če želimo, z rimskimi številkami (I, II, III ...) številčimo strani od zahvale do konca kazal oziroma seznama kratic. Priloge, ki so dodane na koncu, številčimo prav tako z arabskimi številkami, vendar začnemo znova od številke 1.

Za številčenje na zgoraj opisan način moramo na ustreznih mestih obvezno vstaviti prelome odseka na naslednjo stran, nato pa pri oblikovanju številke strani izbrati, s katero številko želimo začeti in kje. Dodatno si lahko pomagamo z različnimi Wordovimi opcijami v orodju za glavo in nogo.

\section{- Seznami}

Kadar naštevamo, v prvi vrsti izbiramo/ločujemo med številčnim in vrstičnim seznamom; prvega uporabimo, kadar je vrstni red naštetega pomemben, drugega pa, kadar vrstni red ni pomemben. Številske oziroma znakovne oznake uporabljamo enotno skozi celoten dokument, kar pomeni, da vedno uporabljamo eno vrsto/obliko števil oziroma eno vrsto/obliko oznak. Smiselno je, da sta vrstična oznaka in začetek besedila primerno zamaknjena glede na levi rob (vendar enotno skozi celo besedilo). Pri večravenskem seznamu smiselno zamikamo vsako naslednjo raven za $1 \mathrm{~cm}$ proti sredini (kar pa ne velja za naslove poglavij).

Začetek seznama naj ne bi bil ločen od zadnje vrstice predhodnega besedila (s katerim je povezan), od nadaljnjega besedila pa ga ločuje prazna vrstica. Pri naštevanju ne smemo pozabiti na ločila: pri kratkih navedbah začnemo z malo začetnico, uporabljamo lahko vejico ali podpičje, naštevanje pa zaključimo s piko (izjemoma lahko ne uporabljamo ločil); daljše besedilo (povedi) naštevamo v obliki stavkov (velika začetnica + pika). 
Skozi zgornje odstavke smo se večkrat sklicevali na t. i. sloge, ki so v veliko pomoč (in izjemno uporabni) pri tehničnem urejanju besedila. Preden zares oblikujemo nalogo, jih je smiselno nastaviti in prilagoditi za uporabo, saj nam močno olajšajo in pohitrijo delo. Večina je programsko prednastavljenih, vendar vsi ne ustrezajo pričujočim navodilom za pisna dela; lahko pa jih spremenimo in spremembe tudi obdržimo. S slogi oblikujemo celotno besedilo: tako glavni tekst kot naslove, napise, sezname ipd. Tudi naslove, ki jih ne želimo uvrstiti v kazalo vsebine (Povzetek, Kazala itd.), lahko oblikujemo s slogi, kar v navodilih sicer ni izrecno omenjeno. $\mathrm{V}$ vseh primerih lahko s slogi uredimo vse nastavitve, ki jih od nas zahtevajo navodila (razmik pred in po, poravnava, morebiten zamik besedila itd.).

\section{- Kazala}

Kazalo vsebine je urejen prikaz strukture našega dela z naslovi vseh poglavij in podpoglavij, ki prikazuje tudi vsebinsko členitev pisnega dela. Smiselno ga je oblikovati po zaključku pisanja besedila. Običajno ima tri ravni, izjemoma (pri obsežnejših delih) tudi več. Vstavljanje kazala je $v$ Wordu enostavno, $v$ kolikor smo dosledno uporabljali sloge. Prvo poglavje $v$ kazalu je Uvod; vsi elementi naloge pred njim v kazalo niso vključeni.

Tehnične podrobnosti oblikovanja kazala vsebine so sledeče: naslovu Kazalo ( $v$ velikosti 16 pik, velike črke) sledi prazna vrstica (12 pik), nato pa prikaz celotne vsebine, pri čemer uporabimo velikost pisave 12 pik, ki je na 1 . ravni odebeljena in ima velike črke, na 2. ravni imamo klasične nastavitve, na 3. ravni pa lahko pisavo tudi zmanjšamo na 11 pik. Povezava s številko strani (vodilna črta) so pike.

Vse grafične elemente (fotografije, grafične prikaze, ilustracije ipd.), razen tabel, označimo z napisom Slika. Kazalo slik umestimo na stran, ki sledi Kazalu vsebine. Naslovu Kazalo slik (velikost 16 pik) sledi prazna vrstica (12 pik), nato pa slike po vrstnem redu, kakor si sledijo skozi pisno delo. Kazalo slik ima v celoti klasične nastavitve pisave (12 pik, male črke), povezava s številko strani (vodilna črta) so pike.

Kazalo tabel lahko od kazala slik ločimo z dvema praznima vrsticama (24 pik) in ni potrebno, da ga umestimo na novo stran. Naslovu Kazalo tabel (16 pik) sledi prazna vrstica (12 pik), nato pa tabele po vrstnem redu, kakor si sledijo skozi pisno delo. Vse ostalo oblikovanje je enako kot pri kazalu slik.

Kazalo slik in tabel se z ustreznim ukazom v Wordu izpišeta avtomatično, za to pa je potrebno predhodno vse naslove oziroma napise slik in tabel ustrezno označiti v zavihku Sklici z izbiro možnosti Vstavi napis.

Kazalo prilog vstavimo šele za naslovom Priloge. Najbolje je, da naslove prilog označimo s posebnim slogom in nato z ukazom Kazalo vsebine po meri uredimo kazalo samo za priloge. Za lažjo izvedbo priporočamo ogled ali uporabo priložene predloge za zaključna dela oziroma seminarske naloge.

\section{- Seznam kratic}

Kratice ob prvi omembi besedila izpišemo s celotno besedno zvezo in jih ob tem pojasnimo $v$ oklepaju, kjer zapišemo tudi, kakšno obliko zapisa bomo uporabljali v nadaljevanju. Od tega trenutka dalje lahko $v$ tekstu venomer uporabljamo zapis $v$ obliki kratice. $\mathrm{V}$ kolikor imamo $\mathrm{v}$ 
tekstu več (kot 10) kratic, jih pojasnimo v posebnem poglavju Seznam kratic, ki stoji za Kazalom tabel.

Seznam kratic oblikujemo na enak način kot prej obravnavani kazali slik in tabel. Smiselno ga je, če je kratic veliko, umestiti na svojo stran. V nasprotnem primeru lahko z razmikom dveh praznih vrstic (24 pik) sledi kazalu slik. Velikost naslova Seznam kratic je 16 pik, za njim je prazna vrstica, nato pa pojasnjene kratice $z$ velikostjo pisave 12 pik.

\subsubsection{Posebni elementi pri oblikovanju dela}

Zaključna dela (diplomska in magistrska) vsebujejo nekatere elemente, kot so platnice trde vezave, povzetek, ključne besede in zahvala, ki pri ostalih delih niso obvezni (lahko pa so izredno določena z navodili za pripravo dela). Oblikovanje posameznih elementov je izrecno opredeljeno in predstavljeno $v$ nadaljevanju. Na tem mestu velja še enkrat izpostaviti zgoraj omenjeni predlogi, ki prav pri oblikovanju teh elementov prideta najbolj v pomoč.

\section{ZUNANJA NASLOVNA STRAN TRDO VEZANEGA IZVODA}

Na platnici trdo vezanega izvoda podatke navedemo z uporabo enojnega razmika in brez dodajanja presledka pred in za besedilom. Velikost pisave je 16 pik, izjema je vsebinski naslov, ki ima velikost pisave 20 pik in je odebeljen, poravnava je na celotni strani sredinska. Pozornost velja nameniti tudi velikim in malim tiskanim črkam. Predlagamo, da se za oblikovanje zunanje naslovne strani uporabi predloga, ki je ustvarjena $v$ ta namen in je priloga teh navodil. $V$ kolikor predloga ni uporabljena, mora biti zunanja naslovna stran oblikovana identično kot v predlogi.

Ne gre pozabiti tudi na določila 3. oz. 4. odstavka 12. člena Pravilnika o postopku priprave in zagovora zaključnega dela na študijskih programih prve in druge stopnje Fakultete za turizem $\mathrm{UM}^{7}$, ki opredeljujeta barvo platnic in pisave, kar je pomembno ob oddaji zaključnega dela $v$ tisk.

\section{NOTRANJA NASLOVNA STRAN}

Notranjo naslovno stran trdo vezane verzije, ki je hkrati prva stran mehko vezane verzije, oblikujemo podobno kot zunanjo naslovno stran. $V$ spodnji polovici strani dodamo mentorja in somentorja (velikost pisave 14 pik). Oblikovanje bo (kot pri zunanji naslovni strani) najlažje, če uporabite predlogo ali se po njej zgledujete.

\section{ZAHVALA, POVZETEK IN KLJUČNE BESEDE}

Drugi sklop elementov, kamor sodijo zahvala, povzetek in ključne besede (pa tudi kazala; vse do uvoda), ločimo, predvsem zavoljo lažjega oblikovanja, od naslovnih strani s prelomom odseka na naslednjo stran. Strani s temi elementi ni treba številčiti. Če se vseeno odločimo za številčenje, uporabimo rimske številke (I, II, III ...). Pred temi elementi je treba $v$ naše zaključno delo (skladno s predlogo in navodili) vstaviti tudi Izjavo o avtorstvu in morebiten dodatek o začasni nedostopnosti dela.

\footnotetext{
${ }_{7}$ Pravilnik o postopku priprave in zagovora zaključnega dela na študijskih programih prve in druge stopnje Fakultete za turizem UM je bil sprejet 30. 3. 2017 in je dostopen na spletni strani fakultete (oziroma prek povezave).
} 
Zahvalo napišemo, če se želimo posebej zahvaliti tistim, ki so nam kakorkoli pomagali pri nastanku pisnega dela. Oblikovanje je prikazano v predlogi. (Opis oblikovanja: naslovu Zahvala (12 pik, velike črke, krepko) sledi prazna vrstica (12 pik) in besedilo zahvale (velikost 12 pik), ki je, kot vse ostalo besedilo, obojestransko poravnano. Razmik vrstic je enojen. Celoten tekst je pomaknjen na spodnji rob strani.)

\section{- Povzetek in ključne besede}

Povzetek običajno vsebuje od 150 do 200 besed. Naslov dela (velikost 16 pik, velike črke) je od besedila povzetka ločen z razmikom 12 pik. Besedilo povzetka je zapisano z običajno velikostjo pisave (12 pik), poravnano obojestransko.

Povzetku sledi prazna vrstica (12 pik) in nato Ključne besede, ki jih pišemo z običajno velikostjo pisave (12 pik) in odebeljeno, za besedno zvezo pa stoji dvopičje. Navadno izberemo okoli pet ključnih besed.

Sledita dve prazni vrstici (24 pik), nato pa celotno vsebino zapišemo še $v$ angleškem ali nemškem jeziku.

V zaključnih delih uvrstimo na isto stran še številko UDK (univerzalna decimalna klasifikacija), ki jo zapišemo po vzoru predloge ( 24 pik pod ključne besede $v$ tujem jeziku).

V primeru oblikovanja vseh strani do kazal se je verjetno najbolje poslužiti predloge, nadalje pa je predlogi (ki prikazuje uporabne primere) priporočljivo slediti, vsebino pa seveda oblikujemo in pripravljamo sami.

\subsection{Namesto zaključka}

Prva skrb avtorjev pisnih del mora seveda ostajati vsebina. Vendar pa še tako kakovostno vsebino brez ustreznega prikaza (strukturiranja in oblikovanja) zelo težko predamo bralcu. Smiselna struktura oziroma zgradba vsebine in njen urejen izgled sta ključnega pomena za njeno širjenje med slušatelje in bralce. Nikakor torej ne gre podcenjevati oblikovalskega dela (zgradbe in urejenosti besedila), saj največkrat predstavlja prvi stik vsebine z občinstvom - in ta je zelo pomemben. Pisno delo je kvalitetno, če zajema in upošteva vse vidike dobrega sporočanja (predstavljene tudi $v$ tem priročniku). In kvalitetno je le toliko, kolikor je kvaliteten njegov najšibkejši člen.

\section{Viri poglavja:}

Fakulteta za turizem. (2017). Pravilnik o postopku priprave in zagovora zaključnega dela na študijskih programih prve in druge stopnje Fakultete za turizem UM. Brežice: Fakulteta za turizem, Univerza v Mariboru.

Sternad, S., Boršič, D. in Tominc, P. (2013). Navodila za izdelavo pisnih del na Ekonomskoposlovni fakulteti. Maribor: Univerza v Mariboru, Ekonomsko-poslovna fakulteta. 


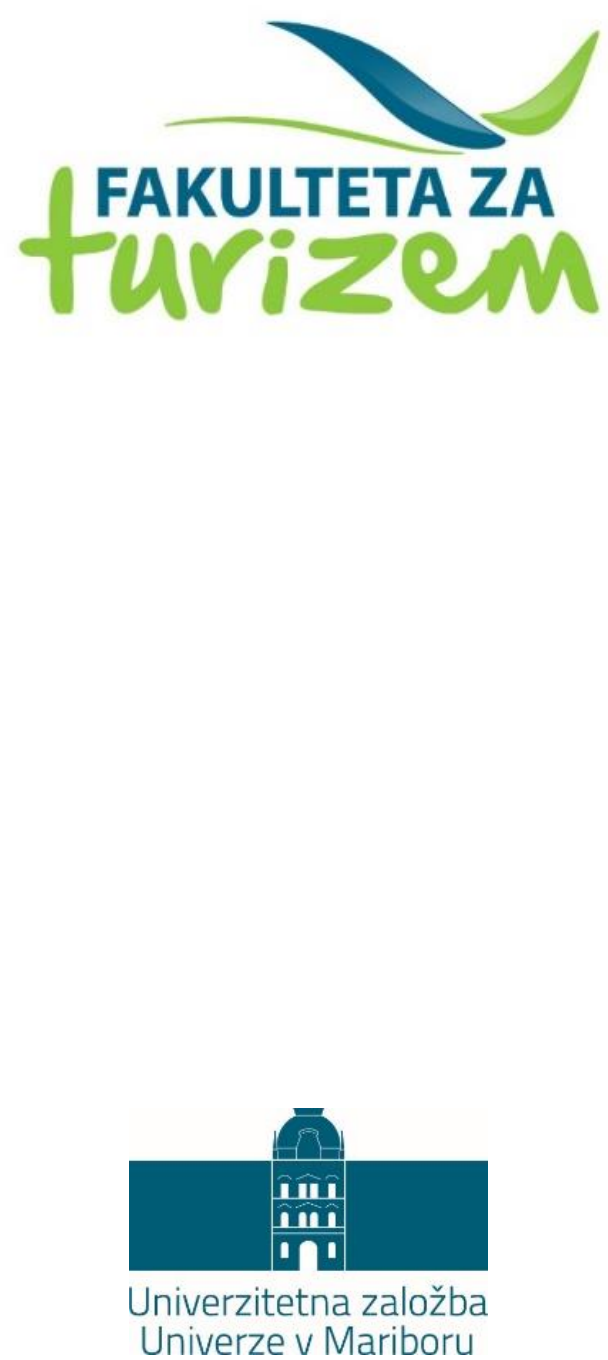